\title{
Contributions of paleoecology to Easter Island's prehistory: a thorough review
}

\author{
Valentí Rull \\ Laboratory of Paleoecology, Institute of Earth Sciences Jaume Almera (ICTJA-CSIC), C. Lluís Solé i Sabarís \\ s/n, 0828 Barcelona, Spain, email: vrull@ictja.csic.es
}

\begin{abstract}
Easter Island (Rapa Nui) is well known for the enigmas surrounding its unique megalithic statues, the moai, and the prehistoric (i.e., pre-European contact) Rapanui society that built them. These enigmas include, among others, the time of the island's settlement, the geographical origin of the first settlers, the technology associated with moai transportation and emplacement, the occurrence (or not) of an ecological and cultural collapse linked to the island's deforestation, and the potential influence of climatic shifts on ecological and cultural changes. Until recently, most explanations for prehistoric developments invoked anthropogenic causes, but the recent development of paleoecological studies has incorporated a new perspective in which climate change and climate-human synergies have gained momentum. This paper reviews all paleoecological studies published to date and their contribution to a better understanding of Easter Island's prehistory, with a focus on four main aspects: (i) the discovery and settlement of the island, (ii) the occurrence of climatic changes, (iii) spatiotemporal deforestation patterns, and (iv) the relationship between environmental, ecological and cultural shifts. Paleoecological research on Easter Island has proceeded through three main phases: a pioneer phase (1977-1992), a transitional phase (1993-2004) and a revival phase (2005-2020). During the pioneer and transitional phases, the paradigm of a self-induced prehistoric socioecological collapse dominated the scene. However, new empirical evidence obtained during the revival phase highlighted the potential importance of climate change in prehistoric ecological and cultural developments. In addition, paleoecological records have provided novel insights into the initial discovery and occupation of Easter Island before Polynesian settlement. Paleoecological evidence has suggested or supported that (i) the island would have been discovered and sporadically/intermittently settled, possibly by Amerindian cultures, long before Polynesian colonization; (ii) climatic changes, especially centennial-scale droughts that occurred during the Medieval Climate Anomaly (MCA) and the Little Ice Age (LIA), would have influenced ecological trends and cultural developments; (iii) deforestation was not a synchronous islandwide process but occurred at different times and at different rates according to the catchment considered; and (iv) both climatic and anthropogenic drivers, along with feedbacks between them, would have been responsible for the prehistoric socioecological developments on Easter Island. A general conclusion is that Easter Island's prehistory is a complex issue that cannot be resolved using simplistic and deterministic approaches from isolated disciplines. Rather, uncovering this prehistory requires an integrated framework with contributions from complementary research fields such as anthropology, archaeology, ethnography, history and paleoecology, among others. This paper explains the potential contributions of paleoecology, in the hope that researchers in other disciplines will be able to incorporate the available paleoecological knowledge into their own studies.
\end{abstract}

\section{Keywords}

Paleoecology, paleoclimatology, last millennium, early settlement, deforestation, cultural shifts 
This paper is a non-peer reviewed EarthArXiv preprint

\section{Introduction}

The prehistory of Easter Island (Rapa Nui in Polynesian language) is considered to be the time between Polynesian settlement and the arrival of the first Europeans, a period during which the Easter Islanders, or Rapanui, did not know writing and metals. The exact date of Polynesian colonization is still under discussion and ranges from approximately $800 \mathrm{CE}$ to $1200 \mathrm{CE}$, depending on the authors (Flenley \& Bahn, 2003; Hunt \& Lipo, 2006; Kirch, 2010; Wilmshurst et al, 2011). European contact took place 5-9 centuries after (1722 CE) and profoundly changed the life and culture of the ancient Rapanui, who were suddenly immersed in history, but others' history rather than their own (Fischer, 2005; Boersema, 2015). The prehistoric Rapanui developed a buoyant society, which has become famous because of the iconic megalithic statues known as moai and all activities related to them, including carving, transportation and emplacement in their final destinations, and the also emblematic stone platforms called ahu, which are widespread across the island (Van Tilburg, 1994; Lipo \& Hunt, 2005; Lipo et al., 2013). At some point, which is also debated and has been situated between approximately $1500 \mathrm{CE}$ and $1680 \mathrm{CE}$ by different authors (Smith, 1961; Mulloy, 1970; Kirch, 1984; Nunn, 2007; McCall, 2009), the megalithic culture ended. This cessation was linked by some authors to a socioecological collapse resulting from human overexploitation of the island leading to total deforestation and a general exhaustion of natural resources (Mulloy, 1974; Bahn \& Flenley, 1992). This view, also known as the ecocidal hypothesis, has become paradigmatic and has dominated not only scientific research but also mass media and public opinion for decades. In this context, Easter Island has been considered a microcosmic model for what might happen worldwide under current exploitation practices (Bahn \& Flenley, 1992; Diamond, 2005). Deforestation would have occurred between 1200 and 1450/1650 CE, with or without the help of Polynesian rats, which ate palm-tree fruits, thus hindering forest regeneration (Dransfied et al., 1984; Hunt, 2006, 2007; Mieth \& Bork, 2010). Other authors contend that deforestation did not lead to a cultural collapse and that the prehistoric Rapanui society remained healthy after forest clearing by developing novel cultivation strategies (Mulrooney, 2013; Mieth \& Bork, 2015, 2017; Stevenson et al., 2015; Jarman et al., 2017; Wozniak, 2017). According to this view, the true collapse of the Rapanui society occurred after European contact and was actually a case of genocide caused by slave trading, acculturation and the introduction of epidemic diseases hitherto unknown by the Rapanui (Rainbird, 2002; Peiser, 2005; Hunt, 2006, 2007). The possibility of two Rapanui population reductions has also been suggested, the first linked to deforestation and the second as a consequence of European contact (Brandt \& Merico, 2015).

In the absence of written documents, prehistoric cultural developments on Easter Island have been inferred mainly from archaeological, ethnographical and anthropological evidence. Until recently, the main paleoecological contribution was confirmation that the island's deforestation actually occurred (Flenley \& King, 1984; Flenley et al., 1991), which supported the ecocidal hypothesis initially proposed by earlier archaeologists (Mulloy, 1974). Until recently, Easter Island's prehistory was viewed under a human-deterministic perspective (Rull, 2018), and the potential action of environmental change was ignored or explicitly neglected. A constant in Easter Island's research, including the mentioned pioneering paleoecological works of Flenley and coworkers, was the idea that the climate remained constant or that its small variations were not influential in prehistoric socioecological developments. Some researchers suggested the possibility that climatic changes, especially droughts, were involved in the ecological and cultural collapse, but evidence of local climate shifts remained absent (McCall, 1993; Haberle \& Chepstow-Lusty, 2000; Orliac \& Orliac, 1998; Hunter-Anderson, 1998; Nunn, 2000; Nunn \& Britton, 2001). Most of these proposals were based on climate change records from distant sites (e.g., Australasia, New Zealand and South America) and regional paleoclimatic reconstructions. Regarding regional mechanisms of climate change, the potential influence of interannual shifts in ENSO (El NiñoSouthern Oscillation) activity was the main candidate, but its eventual influence on Easter Island's climate remained controversial (Maclntyre, 2001; Genz \& Hunt, 2003; Stenseth \& Voje, 2009; Caviedes $\&$ Waylen, 2011). During the last decade, paleoecological studies have intensified, and direct evidence of 
climatic changes on the island has been obtained (Mann et al., 2008; Sáez et al., 2009; Cañellas-Boltà et al., 2013; Rull et al., 2013, 2015, 2016). It has also been demonstrated that deforestation was not homogeneous in time and space, instead occurring at different times and at different rates across the island (Rull, 2020a). Paleoecological research has also contributed to improving knowledge about prehistoric Polynesian cultivation by identifying the locations of agricultural areas and the plants that grew in them (Horrocks \& Wozniak, 2008; Horrocks et al., 2012a, b, 2013, 2015, 2016). Finally, although paleoecology has not provided direct evidence for a number of Easter Island's cultural matters, it has furnished empirical information that can help understand processes such as initial discovery (Rull, 2019) or the potential role of climate changes and climate-human synergies in several cultural aspects (Rull, 2016a, 2020b).

This paper provides a comprehensive and updated review that includes the latest paleoecological improvements and highlights the contribution of paleoecological knowledge to the understanding of Easter Island's prehistory. The review aims to provide a complete and organized paleoecological background for paleoecologists and to facilitate full access to the available paleoecological information for interested researchers in other disciplines. More specific objectives are to emphasize the relevance of paleoecological evidence for elucidating aspects such as settlement, climate change, deforestation and cultural shifts. The review begins with a brief summary of the present-day features of the island, with an emphasis on paleoecological archives that have provided data for past environmental and ecological reconstructions. The second part is an attempt to summarize the main cultural developments of Easter Island's prehistory, to situate further paleoecological information in a consistent chronological context. This section is based on the available archaeological literature, which is presented as is, with no further discussion. The next section uses a historical perspective to disclose the most relevant paleoecological results obtained to date for Easter Island. This section is subdivided into three main phases, i.e., the pioneer phase (1977-1992), the transitional phase (1993-2004) and the revival phase (2005-2020). Then, the paper discusses the main paleoecological results obtained with a focus on four main targets: (i) the possibility of early settlement before Polynesian colonization; (ii) the occurrence of local climatic changes, especially droughts; (iii) the occurrence of spatiotemporal heterogeneities in deforestation timing and rates; and (iv) the potential relationships between environmental changes and sociocultural shifts.

\section{The island and its paleoecological archives}

\subsection{Geographical setting, climate and hydrology}

Easter Island is a tiny island $\left(164 \mathrm{~km}^{2}\right)$ isolated in the SE Pacific Ocean $\left(27^{\circ} 03^{\prime} 17^{\prime \prime}-27^{\circ} 11^{\prime} 42^{\prime \prime} \mathrm{S}\right.$ and $109^{\circ} 27^{\prime} 00^{\prime \prime}-109^{\circ} 13^{\prime} 40^{\prime \prime} \mathrm{W}$ ), located $>2000 \mathrm{~km}$ from the nearest Polynesian archipelago and $>3000$ $\mathrm{km}$ from South America (Fig. 1). Geographically, the island is part of Polynesia, but politically, it has belonged to Chile (in southern South America) since 1888. The island has a triangular shape (Fig. 2) due to the coalescence of three major volcanoes: the Kao, the Poike and the Terevaka, the latter being the highest summit of the island, with a $511 \mathrm{~m}$ elevation, followed by Poike $(370 \mathrm{~m})$ and the Kao $(324 \mathrm{~m})$ (Fig. 1.1). Easter Island is the emerged part of a large volcanic complex rising from the seafloor at a depth of more than $2000 \mathrm{~m}$, as part of the Easter Seamount Chain, a $2500 \mathrm{~km} \mathrm{~W}$-E alignment of volcanic seamounts situated in the westernmost part of the Nazca Plate (Vezolli \& Acocella, 2009).

The present-day climate on Easter Island is subtropical, with small seasonal temperature variations due to oceanic influence. The annual average temperature is $21^{\circ} \mathrm{C}$, with a gentle seasonal range of $5{ }^{\circ} \mathrm{C}$ on average, between $18{ }^{\circ} \mathrm{C}$ in the Austral winter (July-September) and $23-24^{\circ} \mathrm{C}$ in the Austral summer (January-March). Extreme temperatures vary between approximately $15{ }^{\circ} \mathrm{C}$ and $28{ }^{\circ} \mathrm{C}$ (Herrera \& Custodio, 2008). The total annual rainfall ranges between 1100 and $1300 \mathrm{~mm}$, with an average of 140 rainy days. The average seasonal variability ranges between minima of $70-80 \mathrm{~mm} /$ month (November- 
December) and maxima of $100-130 \mathrm{~mm} /$ month (April-June). Potential evapotranspiration is approximately $850-950 \mathrm{~mm} /$ year; therefore, the climatic hydrological balance, or precipitationevapotranspiration ratio (PE), is above 1 , which means that there is no water deficit during a typical year (Herrera \& Custorio, 2008). The seasonal variability in precipitation is controlled by the interplay between three climate systems: the South Pacific Anticyclone (SPA), the South Pacific Convergence Zone (SPCZ) and the westerly storm tracks (Fig. 3). During the Austral fall/winter, the weakening and northern migration of the dry SPA favor the progression of humid westerlies, which carry abundant moisture after their passage by the SPCZ, towards the island, thus causing the April-June precipitation increase. During the Austral spring/summer, the SPA migrates southward and prevents the westerly storm fronts from reaching Easter Island, which receives minimum precipitation (Garreaud \& Aceituno, 2001; Sáez et al., 2009).

Interannual variability in precipitation is very high, ranging from 500 to more than $1800 \mathrm{~mm} /$ year (Azizi \& Flenley, 2008). This variability is largely unpredictable, as it has not been possible to associate longterm precipitation changes with interannual periodic climatic oscillators, such as the El Niño Southern Oscillation (ENSO). According to Maclntyre (2001) and Genz \& Hunt (2003), Easter Island is unaffected by ENSO cyclicity, likely due to its geographical position, where the fluctuations of the Southern Oscillation Index (SOI), a parameter commonly used to estimate the strength of ENSO activity (Trenberth, 2019), are minimal or near zero. However, other studies reported a potential influence of ENSO variability on Easter Island's climate. For example, a study of sea surface temperature (SST) around the island showed that negative SST anomalies coincided with ENSO events (Glynn et al., 2003). Additional support was obtained in a study of an annually banded coral core obtained from the Ovahe beach (Fig. 2), which provided an oxygen isotope record (a proxy for SST) for the period 1944-1997. The spectral analysis of this record showed that the main source of SST variability was the annual cycle (Mucciarone \& Dunbar, 2003). However, a small peak near the 4-year band, which is within the frequency of ENSO variability (Trenberth, 2019), suggested a potential influence of this phenomenon on interannual variability.

Despite the humidity of Easter Island's climate, surface freshwater sources are scant. Permanent surficial water currents and springs are absent due to the high permeability of the island's volcanic rocks and the existence of abundant fractures (Herrera \& Custodio, 2008). After a rain event, surface water flows for only hours to a few days (Brosnan et al., 2018). The only stable freshwater bodies are two lakes (Kao and Raraku) and a swamp (Aroi) located within volcanic craters, a combination locally known as rano (Fig. 4). There is also a groundwater system where freshwater accumulates on top and salinity increases with depth due to the penetration of seawater from below, which creates a density gradient (Herrera \& Custodio, 2008) (Fig. 5). This groundwater system is shallower along the coasts, where natural brackish seeps may occur (Brosnan et al., 2018). Therefore, freshwater is more accessible in coastal environments, especially after heavy rainfall events, where wells for human use are common today. Lakes Kao and Raraku are fed solely by precipitation and are hydrologically disconnected from the groundwater system. Rano Aroi, situated at a 430 m elevation, is an exception, and its swamp is thought to be fed by groundwater penetrating the volcanic core (Herrera and Custodio, 2008). The three ranos are also the only sites with aquatic sediments suitable for paleoecological investigations.

\subsection{Flora and vegetation}

Regarding the flora of Easter Island, some taxonomic and biogeographic studies have been performed on lichens (Follman, 1961), bryophytes (Ireland \& Belliolio, 2002; Grolle, 2002) and pteridophytes (Meyer, 2003), but angiosperms are the best-known group (Zizka, 1991). There are no gymnosperms in the wild, and only some species are cultivated around the capital, Hang Roa (Fig. 2). According to Zizka (1991), the known angiosperm flora of the island is composed of approximately 180 species, less than $17 \%$ of which are considered to be autochthonous (idiochores), almost $80 \%$ of which were introduced 
by humans (anthropochores), and the remaining $4 \%$ of which are of uncertain origin. Given the isolation of Easter Island, the ways in which the idiochorous species reached the island are of special significance. Interestingly, none of the autochthonous angiosperms have the potential for wind dispersal, with the main mechanisms being transport by birds (75\%) and drift through seawater (25\%) (Carlquist, 1967, 1974). Most of the anthropochore species were introduced after European contact, and only a few species were carried by the first Polynesian settlers for cultivation purposes. Only 3(4) extant species are considered endemic to the island: Axonopus paschalis (Poaceae), Danthonia paschalis (Poaceae), Sophora toromiro (Fabaceae), and probably Paspalum forsterianum (Poaceae) (Zizka, 1991). Among them, the toromiro (S. toromiro) has been considered extinct in its natural habitat for the past 50 years and is maintained only by cultivation on the island and in several botanical gardens elsewhere (Maunder et al., 2000). The flora of Easter Island is considered exceptionally poor, especially in woody species. This was first noted by Skottsberg (1920-1956), who observed that the flora of the island was poorer than that of other oceanic islands with comparable size, geology, elevation and climate and attributed this phenomenon to the exceptional isolation of Easter Island (see also Dumont, 2002). In contrast, Van Balgooy (1960) believed that many species went extinct as a result of human activities.

The vegetation of Easter Island is fully degraded and anthropized. Today, the island is largely covered by grass meadows (90\%), with very low forest $(5 \%)$ and shrubland (4\%) cover; pioneer and urban vegetation represent 1\% of the surface cover (Etienne et al., 1982). Fig. 6 shows more details of these vegetation units. Meadows have a variable soil cover, ranging from $25-50 \%$ on the southern coasts to $75-100 \%$ in the N, NW and E sectors of the island. Most meadows are dominated by two widely distributed grasses, Sporobolus africanus and Paspalum scrobiculatum, but the Terevaka uplands are dominated by the endemic grass Axonopus paschalis and the sedges Pycreus polystachyos and Kyllinga brevifolia. Shrublands, with typical soil cover between 50 and $75 \%$, are largely dominated by the invader Psidium guajava (Myrtaceae), introduced from tropical America. Other relevant introduced shrubs include Crotalaria spp. (Fabaceae) and Dodonaea viscosa (Sapindaceae), which probably escaped from cultivation. The forests are all planted, and their soil cover is highly variable (50-100\%). Most forests are recent plantations of Eucalyptus spp. (Myrtaceae), introduced from Australia; Dodonaea viscosa (Sapindaceae), carried from tropical America; the widely distributed Melia azedarach (Meliaceae); and Thespesia populnea (Malvaceae), which some authors consider an idiochore and others consider an anthropochore (Zizka, 1991). There is also a plantation of coconut (Cocos nucifera; Arecaceae) in the bay of Anakena (Fig. 2). The vegetation of the ranos is dominated by the aquatic species Scirpus californicus (Cyperaceae) and Polygonum acuminatum (Polygonaceae), both also occurring in tropical America, along with several native fern species.

The present vegetation of Easter Island is completely different from the preanthropic vegetation that existed before Polynesian settlement. Since then, the original landscape has been severely degraded with time and replaced by a totally cultural landscape. This degradation occurred in two main phases. Before Polynesian arrival, the island was covered by palm-dominated forests that were fully removed before European contact (1722 CE), during the development of the ancient Rapanui culture. The evidence for this deforestation is mostly paleoecological (Flenley \& King, 1984; Flenley et al., 1991). Polynesians also introduced cultivated plants such as Broussonetia papyrifera (Moraceae), Colocasia esculenta (Araceae), Cordyline fruticosa (Asparagaceae), Dioscorea alata (Dioscoreaceae), Ipomoea batatas (Convolvulaceae), Lagenaria siceraria (Cucurbitaceae) and Musa sp. (Musaceae). This has been documented by historical reports and fossil remains in soils from former agricultural drylands and lake shore terraces (Zizka, 1991; Wozniak et al., 2007; Horrocks \& Wozniak, 2008; Horocks et al., 2012a, b, $2013,2015,2016)$. Other cultivated or useful plants mentioned by earlier European visitors include Thespesia populnea (Malvaceae), Curcuma longa (Zingiberaceae), Saccharum officinarum (Poaceae) and Sapindus saponaria (Sapindaceae), the last of doubtful origin. Most of these aboriginal introductions, however, are no longer present or cultivated on the island (Zizka, 1991). Landscape degradation did not stop with forest clearance and Rapanui land use but was exacerbated after European contact (McCall, 
1981; Fischer, 2005; Boersema, 2015). Major deterioration occurred in 1875 CE, when the whole island was transformed into a ranch, mostly for sheep. This initiated the second island-wide degradation after deforestation. Former forest removal had already eliminated the palm forests, but intensive and extensive grazing removed most of the autochthonous plant species that remained. After a pause in which more alien species were introduced, notably coconut trees (Cocos nucifera), a second and even more intense landscape degradation event took place as a result of the reactivation of extensive livestock practices. In 1903, the number of sheep in the ranch increased to approximately 70,000 (430 per $\mathrm{km}^{2}$ ), and the island experienced the worst vegetation deterioration of its entire history.

\subsection{Archaeological heritage}

The most unique and impressive feature of Easter Island's landscape is its archeological heritage, a large part of which is openly exposed in situ across the whole island. According to Vargas et al. (2006), there are more than 20,000 sites or manifestations of archaeological interest on the island, still preserved in their original locations. These manifestations include the abovementioned moai, more than 500 of which are associated with more than 300 ahu, whereas the other ca. 400 are still in the Raraku quarry, except for approximately 60, which were abandoned along transportation roadways (Lipo \& Hunt, 2005; Lipo et al., 2013) (Fig. 2). The size of the moai is variable, but some are $>10 \mathrm{~m}$ high and weigh nearly 90 tons (Fig. 7). Most of these statues were carved from the comparatively soft tuff of the Raraku crater using carving instruments (toki) made of harder basalt (Gioncada et al., 2010). Only 13 moai were made of basalt, 22 of trachyte and 17 of red scoria (Van Tilburg, 1994). Some of the moai bear big cylindrical hats (pukao) made of red scoria (Gioncada et al., 2010; Hixon et al., 2018). A number of moai and moai fragments were removed from the island and are preserved in private collections and museums in continental Chile and elsewhere (New Zealand, Great Britain, France, Belgium, USA and Canada) (McLaughlin, 2007).

Other significant manifestations of the ancient Rapanui culture include the approximately 4200 remains of dwellings (hare) of two main types: the hare paenga, consisting of an elliptical base made of basalt to support thatched roofs, and the hare moa, made entirely of basalt. Other stone constructions include the manavai, approximately 2000 of which have been documented, which were used to protect crops from erosion and evaporation, and the pipi horeko or milestones, to indicate some prohibited sites (tapu) or to divide properties. Deserving of special attention are the approximately 4000 petroglyphs (rona), also known as rock art, with varied motifs including octopuses, sharks, turtles, lizards, chickens, human vulvas and mythic figures, notably the Birdman, which is especially frequent around Orongo (Lee, 1992). Other features and objects include earth ovens (umu), portable artifacts such as stemmed obsidian tools (mata'a), lithic flakes and stone adzes, modified caves and small basins carved in bedrock to collect water (taheta) (Hunt \& Lipo, 2018). There are also extensive subterranean caves, mostly lava tubes, containing some structural remains, portable artifacts and human and animal (fish, rats, chickens, birds, and shellfish) remains (Rorrer 1998; Ciszewski et al., 2009).

\subsection{Sedimentary archives}

As mentioned above, only the three ranos contain sediments suitable for paleoecological research (Fig. 4). Rano Aroi is a swamp (mire) $150 \mathrm{~m}$ in diameter situated at a $430 \mathrm{~m}$ elevation near the Terevaka summit (Fig. 2). The water level is controlled by groundwater inputs subject to influence by seasonal variations in precipitation and human extraction through the construction of an artificial outlet in the 1960s (Herrera and Custodio, 2008). The aquatic vegetation is dominated by Scirpus californicus, Polygonum acuminatum and ferns of the genera Asplenium, Vittaria and Cyclosorus, whereas the surrounding area is covered by grasslands and a small Eucalyptus forest planted during the 1960s (Zizka, 1991). The mire infill is predominantly peat and is at least $16 \mathrm{~m}$ deep in the center, which may represent an age of approximately 70,000 yr BP (extrapolated age) (Margalef et al., 2013, 2014). However, the 
deposit could be deeper and older, as none of the existing sedimentary records reached the bedrock. Flenley et al. (1991) described this organic accumulation as a mixture of coarse detritus and finer material intermingled with layers of spongy monocotyledonous peat and brown clay. Peteet et al. (2003) reported the occurrence of several types of peats and organic clays with fibrous material. A similar composition was described by Horrocks et al. (2015). Margalef et al. $(2013,2014)$ performed a detailed lithological study of the whole stratigraphic sequence and distinguished four main organic facies: A) reddish peat of sedges and Polygonum; B) granulated muddy peat of coarse organic fragments, mainly roots, with a low terrigenous content; C) organic mud or dark-brown to black peat and D) dark-brown, fine-grained peat. Facies $B$ is the best represented throughout the sequence.

Rano Kao contains the largest lake on the island, with a diameter of $1250 \mathrm{~m}$, situated at a $110 \mathrm{~m}$ elevation. This lake is very peculiar, as its surface is a mosaic of water and aquatic vegetation in the form of floating mats up to 3-4 m deep overlying the water column, which is approximately $10 \mathrm{~m}$ deep near the center. This configuration determines the existence of two different palaeoecological archives: the superficial peaty floating mat and the more clastic bottom lake sediments accumulated below the water column. The floating mats are dominated by the characteristic semiaquatic species of the island, Scirpus californicus and Polygonum acuminatum, together with another sedge, Pycreus polystachius (Zizka, 1991). The oldest ages recorded so far in the floating mat correspond to the late millennium (Gossen, 2007; Horrocks et al., 2013). A significant number of archaeological sites have been found within and around Rano Kao, including the ancient village of Orongo, formed by stone houses, which is one of the most important and best preserved archaeological complexes on the island (Robinson \& Stevenson, 2017). The maximum depth of lake sediments recorded thus far is approximately $21 \mathrm{~m}$ (but they should be deeper), and the maximum age is 34,000 cal y BP, although the more typical age for the base of the cores is approximately 20,000 cal y BP (Gossen, 2007, 2010; Horrocks et al., 2013). The Kao lake sediments have been described as coarse organic detritus derived from aquatic and catchment vegetation, with a basal layer of coarse detritus and clay (Flenley and King, 1984; Flenley et al., 1991; Horrocks et al., 2013).

Rano Raraku contains a small and shallow lake with a $300 \mathrm{~m}$ diameter and 2-3 m depth, situated at an $80 \mathrm{~m}$ elevation. Hydrologically, the lake is closed, with no surface outlet, and is used by humans as a freshwater source for consumption and irrigation. The main water inputs are rainfall and catchment runoff (Herrera and Custodio, 2008). The water level is influenced by periodic water extraction, and the maximum depth recorded in modern times is approximately $3 \mathrm{~m}$ (Sáez et al., 2009); however, in some years, the lake may be totally dry (W. D'Andrea, pers. comm. 2018). The aquatic vegetation is dominated by Scirpus californicus, which forms a more or less continuous floating belt (partially rooted in lake sediments) in the eastern margin of the lake (Fig. 4), where the input of terrigenous materials from the catchment is higher and more continuous. Rano Raraku is one of the more emblematic sites of the island, as it was the quarry where the moai were carved. Many of these stone statues, some of them unfinished, still remain on the eastern side of the crater, where most of the moais were built. The sedimentary infill is at least $14 \mathrm{~m}$ deep in the center of the lake, which corresponds to an age of 34,000 cal yr BP (Sáez et al., 2009). These sediments have been described as a mixture of coarse and fine detritus originating from lake and catchment vegetation intermingled with layers of gyttja, clay, mud and, eventually, volcanic ash (Flenley et al., 1991; Horrocks et al., 2012a). A more detailed sedimentological study reported that the Raraku sediments were dominated by organic matter (70-90\% of the total weight), with variable amounts of terrigenous mineral particles from the catchment rocks and pyritic precipitates. The organic matter was a mixture of plant remains from the catchment and, at a lower proportion, autochthonous organic matter derived from lake production (Sáez et al., 2009). The same study distinguished the following four sedimentary facies (from the base to the top): 1) laminated, dark gray-reddish organic-rich silts and mud; 2) laminated and massive brownish organic mud; 3) brownreddish massive or banded peaty sediment, composed mainly of plant (sedge) remains and 4) peat and silty clay. 
This paper is a non-peer reviewed EarthArXiv preprint

Cores from the Aroi, Kao and Raraku sediments have been retrieved from different parts of these ranos using a variety of types of coring equipment and extrusion techniques. Fig. 8 shows the location of all cores obtained to date with published results, whereas Table 1 displays the main features of each core and the main paleoclimatic and paleoecological proxies studied. A database called EIRA (Easter Island Radiocarbon Ages) is publicly available on the NOAA Paleo Data website (www.ncdc.noaa.gov/paleosearch/study/19805) with all radiocarbon dates obtained in these sediments (Rull, 2016b). The total number of calibrated/recalibrated dates is 270 (excluding unreliable ages of $>50$ cal kyr BP), $208(77 \%)$ of which correspond to the Holocene $(11,700-0 \mathrm{cal} y r \mathrm{BP})$ and the remaining $62(23 \%)$ of which are from the Late Pleistocene (48,000 to 17,500 cal yr BP). The rano with the most dates is Raraku ( 120 dates; $44 \%$ ), followed by Raraku ( 85 dates; $32 \%$ ) and Aroi (65 dates; $24 \%$ ). In total, the time interval with the most dates is the last millennium, with a more or less continuous exponential decrease until the Pleistocene, except for a small increase in the Early Holocene. Late Pleistocene dates are scarce, except for the Lateglacial phase (18-12 cal kyr BP). The interval with the fewest dates is 18 to $22 \mathrm{cal} k \mathrm{kr} \mathrm{BP}$, which corresponds to the Last Glacial Maximum or LGM (Azizi \& Flenley, 2008). Individual sites follow similar trends with some variations. In Rano Aroi, Late Pleistocene dates are more frequent, with noticeable gaps in the LGM and the Middle Holocene. Late Pleistocene ages are almost nonexistent in Rano Kao, where most dates are concentrated in the Late Holocene, with very few in the Middle Holocene. In Rano Raraku, the Middle Holocene is better represented than at other sites, and the more abundant Pleistocene ages correspond to the Lateglacial.

\subsection{Other paleoecological archives}

In addition to lake and swamp sediments, other paleoecological archives have been investigated on Easter Island, although less intensively. One is the already mentioned coral record from Ovahe beach, which is the only study of this nature published from Easter Island that has been produced using paleoecological methods. Although this record is limited to modern times (i.e., the second half of the $20^{\text {th }}$ century), the authors of the study believe that the coral records of Easter Island have the potential to span at least 250 years and possibly 400 years (Mucciarone \& Dunbar, 2003). If this is true, these records might be able to provide information beginning in the latter prehistoric times. Studies of soil profiles and selected materials from some archaeological sites have also provided paleoecological information, mainly on the nature of ancient forests and deforestation timing. In several of these archives, Mann et al. (2003) and Mieth \& Bork $(2005,2010,2015,2017)$ found evidence of slash-andburn activities, agroforestry, forest clearing and regeneration, soil erosion and other ecological processes that will be described in more detail in the corresponding sections. In other dryland soils and archaeological sites, Horrocks \& Wozniak (2008) and Horrocks et al. (2016) found evidence for forest clearing and cultivation of Polynesian crops, which will also be further disclosed. The already mentioned archaeological sites where Orliac (2000) and Orliac \& Orliac (1998) identified woody plant taxa from charcoal fragments are also worth mentioning. The proxies usually utilized in these studies include soil stratigraphy, with an emphasis on carbon layers, charred wood/endocarps and palm root casts, which are useful for estimating the palm density of former forests and their clearing times; charred wood; pollen; phytoliths and starch remains.

\section{Prehistoric chronology and cultural developments}

There is no generally accepted chronology for Easter Island's prehistory. A quick look at Fig. 9 shows that most chronologies define three phases or periods that can be summarized as follows: (i) a first phase of settlement with low population density and limited environmental impact, which represented the initiation of the moai industry; (ii) a second phase of cultural expansion with higher population density, intense architectural expansion and high levels of environmental impact; and (iii) a third phase of decadence, characterized, in some cases, by resource depletion, cultural degradation and monument 
destruction. However, despite this more or less general coincidence in prehistorical trends, there is a strong disagreement regarding the ages of these phases/periods and the settlement dates. Therefore, a robust chronology of human developments on Easter Island is still to be defined. Lipo \& Hunt (2016) argued that only the timing of human settlement, which they situated at 1200 CE (Hunt \& Lipo, 2006), and the arrival of Europeans in $1722 \mathrm{CE}$ can be considered reliable dates, and the time between these two events may be described as "the past", with no more precision than that (Fig. 9).

\subsection{Settlement}

The arrival time and origin of the first settlers have been debated for a long time. The first ethnologists working on the island gathered the Rapanui oral tradition, according to which the first Polynesians set off from the Marquesas or the Gambier islands (Fig. 10). The best candidate appeared to be Mangareva Island (Routledge, 1919; Métraux, 1940). Later, Heyerdahl (1952) proposed that Easter Island may have been settled by Amerindian (or Native American) cultures from South America and organized the famous Kon-Tiki expedition to demonstrate that it was possible to navigate from South America (Peru) to Polynesia (Tuamotu Islands) with rudimentary navigation technologies, with the aid of only dominant winds and sea currents (Fig. 10). The underlying hypothesis was that Native Americans could have colonized Easter Island by $400 \mathrm{CE}$ and the Polynesians arrived later and eradicated the Amerindian culture (Heyerdahl \& Ferdon, 1961). This view was dismissed by Felnley \& Bahn (2003), who claimed that Easter Island was colonized only once by Polynesians and this would have occurred by $800 \mathrm{CE}$. Further archaeological evidence supported this view and proposed that the initial Polynesian settlement could have occurred between $800 \mathrm{CE}$ and $1000 \mathrm{CE}$ and the ceremonial sites with worked stones were erected later, between 1100 CE and 1200 CE (Steadman et al., 1994; Martinsson-Wallin \& Crockford, 2002; Vargas et al., 2006). This view was consistent with the general framework of Kirch (2010) for the peopling of the Pacific islands and archipelagos (Fig. 10). However, prehistoric Amerindian influence cannot be disregarded, as recent genetic evidence suggested the presence of Native Americans on Easter Island between 1280 CE and 1495 CE, before the European discovery of America (Thorsby, 2007, 2016). What remains unclear is whether American people reached the island by themselves or were carried by Polynesians in back-and-forth voyages. The second possibility would imply the discovery of America by Polynesians in pre-Columbian times, which is supported by abundant interdisciplinary evidence (Jones et al., 2011).

\subsection{The moai cult}

After settlement, the development of the ancient Rapanui society was linked to the so-called moai cult and the proliferation of the moai industry (carving, transportation, and emplacement), which was the main activity of the islanders. There is a general consensus that the moai represented deified ancestors, likely former clan or lineage chiefs, who were worshiped to ensure the fertility of the earth and the sea, as well as to guarantee the prosperity of the corresponding clans and lineages. The moai were supposed to be under the command of the principal god, Make Make, the only immortal god and creator of all of humankind (Edwards \& Edwards, 2011). According to the Rapanui tradition, the highest authority of the island, the Ariki Mau, had his residence in Anakena (Fig. 1) and was invariably the chief of the Miru clan, in a dynastic system based on direct descent from Make Make. The Ariki Mau was seen to possess mana, a type of supernatural power that separated him from the rest and legitimized his leadership role (Robinson \& Stevenson, 2017). The oldest dated ahu suggests that the moai industry began during the $12^{\text {th }}$ and $13^{\text {th }}$ centuries (Hunt \& Lipo, 2006; Matrinsson-Wallin, 2001; Wallin et al., 2010). The end of the moai industry is more debated, but the general view is that it coincided with the island's deforestation and the subsequent unavailability of wood and ropes needed for moai transportation and emplacement in their respective ahu (Boersema, 2015). According to the evidence available before the paleoecological revival of the last decade, deforestation would have started by $800 \mathrm{CE}$ as a small-scale practice and intensified by $1250-1350 \mathrm{CE}$. Most of the island would have been deforested by $1450 \mathrm{CE}$, and full forest 
removal could have occurred by 1600-1650 CE (Flenley \& Bahn, 2003; Hunt, 206, 2007; Mieth \& Bork, 2010, 2015).

\subsection{The Birdman cult}

The moai cult was replaced by the Birdman cult, which involved a profound social, political and religious reorganization in the Rapanui society. The Birdman cult was based on the idea that a man not directly descending from the gods could acquire an elevated level of mana not because of his genealogical "merits" but because Make Make had chosen him as a physical manifestation of himself and, therefore, the maximum authority of the island (Métraux, 1940). The ceremony in which the chosen man was identified and proclaimed as the Birdman (Tangata Manu) was a yearly athletic competition generally performed by the warriors (matato'a) of different clans. Each year, during the Austral spring, the Rapanui met in the ceremonial village of Orongo, from where the athletes descended the vertical cliffs of the Rano Kao crater by its outer wall to reach the sea and swam until reaching the Motu Nui islet (Fig. 2) to obtain the first egg of the migratory sooty tern or manutara (Onychoprion fuscatus), which was a symbol of fertility. The Birdman and, therefore, the maximum authority of the island was the chief of the clan whose representative was able to return to Orongo with the first egg in intact condition (Routledge, 1919; Métraux, 1940, Englert, 1948). The onset of the Birdman cult has been related to the foundation of the village of Orongo, which took place at or slightly after 1600 CE (Robinson \& Stevenson, 2017), coinciding with the abovementioned cessation of the moai cult and the total island's deforestation. The Birdman cult continued after European contact. Fischer (2005) pointed out that the rivalry among the different clans competing for the Birdman exacerbated after European contact and degenerated into an open battle for destroying their competitors' mana, whose most conspicuous manifestation was their moai. The Birdman cult was prohibited by Catholic missionaries in 1862 , but the contest continued until 1879 , albeit as a purely athletic competition (Routledge, 1914).

\subsection{Resilience}

According to ecocidal theory, deforestation and the general exhaustion of natural resources would have caused starvation, social conflicts, wars and cannibalism (Bahn \& Flenley, 1992; Flenley \& Bahn, 2003; Diamond, 20015; Bahn, 2015). This would have exacerbated the Rapanui cultural and demographic crisis. However, a number of archaeologists contend that the ancient Rapanui were resilient to island deforestation and remained a healthful society until European contact. According to these authors, this was possible thanks to the development of novel cultivation practices. The ancient Rapanui did not practice extensive cultivation or widespread irrigation; crops were restricted to meter-scale garden features, the manavai, whose water supply was heavily dependent on rainfall (Hunt \& Lipo, 2011; Puleston et al., 2017). To minimize evaporation and erosion, the manavai were protected from wind and surficial runoff by rock walls up to $2 \mathrm{~m}$ high, and soils were covered by rocks to preserve heat, moisture and nutrients, a practice called lithic mulching (Stevenson et al., 1999; Wozniak, 1999, 2001). During the first 500 years of human occupation, cultivation was carried out along the coasts and 1-2 km inland, and the main volcanic peaks (Kao, Pike and Terevaka) were likely forested; however, after approximately $1500 \mathrm{CE}$, these forests were also replaced by manavai structures (Mieth \& Bork, 2005). Recent investigations have suggested that these agricultural practices continued, with no significant decline, until European contact (Mulrooney, 2013; Mieth \& Bork, 2015, 2017; Stevenson et al., 2015; Jarman et al., 2017; Wozniak, 2017). Robinson \& Stevenson (2017) suggested that some reduction in arable land could have existed due to soil erosion after deforestation, but this would have caused spatial reorganizations of agricultural practices, leading to cultural continuity rather than a population collapse. In addition, some recent anthropological studies have shown that the diet of the postdeforestation Rapanui people was balanced, with no signs of malnutrition (Commendador et al., 2013, 2019; Polet, 2015; Polet \& Bocherens, 2016; Jarman et al., 2017). 


\subsection{The genocide}

Although this section goes beyond the temporal scope of the paper, it is necessary to highlight that a Rapanui genocide truly occurred, albeit after European contact, and is very well documented historically (Fischer, 2015; Boersema, 2015). The frequency of alien visits to Easter Island between the late $18^{\text {th }}$ century and the mid-19 $19^{\text {th }}$ century increased spectacularly and profoundly disturbed the Rapanui society. In the second half of the $19^{\text {th }}$ century, the situation was aggravated by slave raids organized from South America to provide a labor force for guano extraction and domestic tasks. In 1862, a total of 1400 slaves - roughly one-third of the island's population at that time - were captured on Easter Island. In 1863, human trafficking was prohibited, the repatriation of Easter Islanders began, and 470 Rapanui embarked to return to their original home. However, these "fortunate" people had already contracted infectious diseases hitherto unknown to them, such as syphilis, smallpox and tuberculosis, and only 15 of these Rapanui arrived alive to the island. Smallpox and tuberculosis spread across the island, and a decade later (1877), only 110 living Easter Islanders remained (Pinart, 1878). Meanwhile, acculturation was in progress, and in 1868, missionaries had already Christianized the entire island's population, which included 800 Rapanui. In summary, a real collapse of the Rapanui culture, in the form of genocide, occurred between 1862 and 1877, when the population almost disappeared and the few remaining people had been acculturated.

\section{Historical development of paleoecological studies}

Paleoecological studies of Easter Island originated in some undated cores taken in the mid- $20^{\text {th }}$ century by Thor Heyerdahl, which were analyzed for pollen by Olof Selling but remain unpublished. The only information available is personal communication from Selling to Heyerdahl reporting abundant pollen from an unknown palm already extinct on the island, provisionally assigned to Pritchardia, and the suggestion that the island was probably forested at some time in the past (Heyerdahl \& Ferdon, 1961). These forests must have disappeared before European contact, as the first Europeans to arrive found a treeless island (Fischer, 2005). The idea of a forested island had already been proposed, albeit without empirical evidence, in the late $18^{\text {th }}$ century by La Pérouse (1797), who also speculated that the ancient Rapanui would have cut down all the trees making the island inhabitable. Mulloy (1979) related the initial palynological evidence with his own findings of palm root molds in ancient soils, which were interpreted as remnants of former palm forests. The further finding of carbonized wood remains associated with the root casts was taken as evidence of anthropogenic forest removal (Mulloy, 1974, 1979). In a later paper written in 1976 but not published until a couple of decades later, this author emphasized the need for repeating and extending the paleobotanical studies initiated by Selling to test the hypothesis of a formerly forested island (Mulloy, 1997). From this point onwards, the sediments of the suitable sites (Rano Aroi, Rano Kao and Rano Raraku) began to be systematically cored and dated. However, the historical development of these studies was a discontinuous process due to the occurrence of an impasse of approximately ten years (1993-2004), characterized by a significant reduction in paleoecological activity, which separated the more active pioneer (1977-1992) and revival (2005-2020) phases.

\subsection{The pioneer phase}

The first systematic paleoecological studies based on dated sediments were performed by a single research team led by the palynologist John Flenley. All the work developed during this phase was based on cores obtained between 1977 and 1983 in Rano Aroi, Rano Kao and Rano Raraku. The first published reconstructions suggested that the island would have been covered by palm-dominated forests during the last 37,000 years and that these forests disappeared during the last millennium, probably due to anthropogenic causes, which could have led to a cultural collapse of the prehistoric Rapanui culture (Flenley \& King, 1984). These authors also concluded that the climate was cooler and/or drier than at 
present between 21,000 and $12,000{ }^{14} \mathrm{C} y r \mathrm{BP}$, a time interval that includes the LGM. The taxonomic identity of the palm, however, remained unknown. The pollen was similar to that of several genera, including Cocos and Pritchardia, which are widespread on Pacific islands, or Jubaea chilensis, common on the Pacific coasts of Chile. Of these taxa, only Cocos nucifera occurs today on the island but as a result of recent introductions. Dransfield et al. (1984) reported the finding of several palm endocarps similar in size but with different morphologies compared with those of J. chilensis, and the authors concluded that they were from a palm related to but distinct from this species. Radiocarbon dating of several of these palm fruits gave ages of $820 \pm 40{ }^{14} \mathrm{C}$ years BP, which coincided with the time of deforestation, i.e., the last millennium, and with the flourishment of the moai industry (Dransfield et al., 1984). The endocarps showed clear signs of rodent gnawing that these authors attributed to Rattus concolor, a Polynesian rat probably introduced by the first colonizers. Dransfield et al. (1984) concluded that the extinction of the unknown palm could have been due to "...a combination of direct deforestation and prevention of reproduction, the latter resulting from eating of the fruits by man and the introduced rats". These authors also mentioned that the extinct palm, if similar to J. chilensis, would have been used in the transportation and final emplacement of the moai in their respective ahu, as initially proposed by Mulloy (1970). Based on the same endocarps, Dransfield (in Zizka, 1991) provisionally described a new genus and species of extinct palm, Paschalococos disperta, until more material is available for comparison with known extant genera.

A more comprehensive paper was published several years later by Flenley et al. (1991) using not only pollen but also sedimentological and geochemical proxies, with detailed reconstructions of vegetation and landscape changes, anthropogenic activities and past climatic trends. In these analyses, the shift from palm forests to grass meadows was clear in the Raraku and Kao records (Fig. 11), but the Aroi record showed different patterns of landscape and vegetation dynamics (Fig. 12). In Raraku, dense palm forests have dominated the landscape since at least $35,000{ }^{14} \mathrm{C} \mathrm{yr} \mathrm{BP}$, with a gentle density decrease between 28,000 and $12,000{ }^{14} \mathrm{C}$ yr BP that favored the development of a shrub layer composed mainly of Sophora, Coprosma, Trema, Sapindus and unknown Myrtaceae species (Fig. 11). The forest returned to its original state by $12,000{ }^{14} \mathrm{C} \mathrm{yr} \mathrm{BP}$ and remained that way until $1200{ }^{14} \mathrm{C} \mathrm{yr} \mathrm{BP}$, when it experienced a sharp decline in both palms and shrubs, coeval with an abrupt increase in grasses and other herbs, likely introduced by humans, such as Plantago, Caryophyllaceae, Compositae-Liguliflorae, Rumex and Euphorbia. Although not counted, charcoal particles also increased in this interval. The whole picture was interpreted in terms of forest clearing by humans, presumably by a combination of felling and burning. By the time of development of these pioneer pollen analyses, the accepted date for the initial human settlement of Easter Island was 400 CE (Heyerdahl \& Ferdon, 1961), which was used by Flenley et al. (1991) to support the hypothesis that humans were mainly responsible for forest clearing. Notably, the authors of this study used a linear age-depth model that ignored the possibility of a sedimentary gap of approximately 6400 years between two contiguous samples separated by only $25 \mathrm{~cm}$, with ages of 6850 and $480{ }^{14} \mathrm{C}$ yr BP (Fig. 11). Forest clearing and meadow expansion took place precisely within this interval, and hence, their chronology and temporal patterns would have remained hidden.

The Kao record was restricted to the last $1550{ }^{14} \mathrm{C}$ yr BP and provided more resolution for the deforestation process. In this case, charcoal particles were present throughout the whole record, suggesting permanent anthropogenic forest disturbance. The Kao catchment was forested until $1300{ }^{14} \mathrm{C}$ yr BP, when forest clearing and an increase in grass meadows began. The dominant understory elements, Triumfetta and Sophora, were the first to decline, followed by palm trees (Fig. 12). Total deforestation took place $950{ }^{14} \mathrm{C}$ yr BP, and grass meadows started to dominate the landscape, along with some introduced taxa such as Melia, Casuarina, Trema, Psidium and Apium. The Rano Aroi record was more complex, showing alternating phases of palm forest and shrubland (Compositae/Tubuliflorae and Coprosma) dominance since $38,000{ }^{14} \mathrm{C}$ yr BP (Fig. 12). Flenley et al. (1991) considered Rano Aroi, situated at an approximately $430 \mathrm{~m}$ elevation, to be close to the upper forest boundary (treeline), and the recurrent alternation of palm and shrub pollen indicated small altitudinal fluctuations of this 
treeline, possibly due to small temperature changes. A recent decrease in both palms and shrubs initiated after $2000{ }^{14} \mathrm{C}$ yr BP coincided with an increase in charcoal particles, suggesting anthropogenic burning. The upper part of the diagram was considered useless for paleoecological reconstruction due to the mixing of older and younger sediments, likely by human disturbance in the search for freshwater.

Flenley et al. (1991) highlighted that the expansion of grass meadows at the expense of palm forests recorded in the upper tart of all pollen diagrams was coeval with a drop of organic matter, an abrupt increase in mineral inwashing (especially metallic ions) to the waterbodies and the appearance, for the first time, of charcoal fragments. These authors also emphasized that there were no indications of climatic change associated with the forest decline and that Easter Island's forests had survived all climatic changes that occurred during the last 30,000 years. Therefore, they concluded that human deforestation was the most likely cause for the observed vegetation change. Forest clearing would have happened progressively between 1200 and $800{ }^{14} \mathrm{C}$ yr BP in Rano Raraku and Rano Kao and approximately $1000{ }^{14} \mathrm{C}$ yr BP in Rano Aroi. The total disappearance of forests would have occurred approximately $500{ }^{14} \mathrm{C}$ yr BP, with Rano Kao as the last forested catchment. According to the archaeological chronology of the time, the collapse of the megalithic culture was dated to $1680 \mathrm{CE}$ (Heyerdahl \& Ferdon, 1961) - not too far from $500{ }^{14} \mathrm{C}$ yr BP, according to Flenley et al. (1991) - and was related to island deforestation by Mulloy (1970), who considered timber to have been essential to move the moai. Flenley et al. (1991) concluded that Easter Island's deforestation may have led to an ecological disaster, starting with forest clearance for agriculture and firewood, which led to significant human population growth. The introduction of rats that ate palm fruits prevented the regeneration of palm forests and, together with continued wood exploitation for moving the statues and building canoes, accelerated forest decline and resulted in a food shortage, a decline in statue-carving, warfare and the subsequent human population decline (Fig. 13). In this way, the pioneering paleoecological work on Easter Island strongly supported the ecocidal theory initially conceived by La Pérouse (1797) and explicitly formalized later by Mulloy (1974). Regarding a potential role for climatic change in this ecological and cultural demise, Bahn and Flenley (1992) considered it implausible that forests surviving major climatic fluctuations such as the last ice age and postglacial warming would have perished because of the occurrence of a drought just after the island's colonization by humans. These authors considered this a hard-to-believe coincidence.

In the first socioecological synthesis published after the pioneering paleoecological analyses, Bahn \& Flenley (1992) considered Easter Island to be a microcosm model for the whole planet, as both are isolated systems and have limited resources. Therefore, Easter Island may be viewed as a real experiment on the consequences of overexploitation of natural resources, from which we can extract important lessons for the future of Earth. However, Bahn \& Flenley (1992) devised some difficulties for this lesson to be learned in making such a comparison. One is the selfishness inherent to humans, who prioritize their own short-term goals rather than general social interests, and the other is the current attachment to unlimited growth, which ignores the preservation of natural resources for future generations.

\subsection{The transitional phase}

After the consolidation of the collapse theory by pioneering studies, paleoecological research on Easter Island experienced an impasse of approximately one decade, which is called here the transitional phase. This phase was characterized by sporadic, nonsystematic coring and by the publication of a few papers that did not introduce significant modifications to the collapse paradigm.

In Rano Kao, core KAO2 (Fig. 8, Table 1), which was retrieved in 1983 and remained unstudied, was analyzed during this phase. According to Flenley $(1996,1998)$, Rano Kao was particularly interesting for studying Easter Island's prehistory because - contrarily to the upper sediments in Rano Aroi and Rano 
Raraku, which were disturbed or contaminated by old carbon - the last centuries seemed to be well represented in the upper sedimentary layers. However, it was difficult to establish a reliable age-depth model for core KAO2 due to frequent age inversions, which were explained in terms of the drifting of younger material beneath the floating mat and contamination by older carbon, probably from the inwashing of soils from the steep crater walls as a consequence of human disturbance (Flenley, 1996). To solve this dating problem, more dates were taken using different materials, but age inconsistencies increased, especially in the floating mat (Butler \& Flenley; Butler et al., 2001). These authors concluded that, in the absence of a reliable chronological model for the KAO2 core, it was impossible to draw conclusions about the ecological history of the island. The potential sources of older carbon contaminating younger sediments were discussed by Butler et al. (2004), who dismissed inwashing from crater walls and favored other explanations, such as the occurrence of fine particles derived from the burning of aging trees from the catchment, depleted $\mathrm{CO}_{2}$ emitted as gas from the caldera floor and incorporated by photosynthesis, or erosion of marginal sediments due to the periodic occurrence of low lake levels during climatic droughts. The authors also concluded that the suitability of floating mats as paleoecological archives was doubtful due to the possibility of these mats being inverted or "flipped over" in the past and that bottom lake sediments were better suited to correlate the Rano Kao palynological records with those from Rano Raraku (Butler et al., 2004). These authors recommended caution in the interpretation of the $\mathrm{KAO} 2$ palynological record available at that time and the development of additional coring and new chronologies after careful selection of the materials to be dated. Similar dating problems were encountered in Rano Aroi core RA2 (Fig. 8, Table 1), where the radiocarbon dates obtained were also unsuitable for providing a reliable chronology and, therefore, obtaining a time-ordered paleoecological reconstruction (Peteet et al., 2003).

In Rano Raraku, a core called SW (Fig. 8, Table 1) showed similar dating drawbacks, but Dumont et al. (1998) used a sample dated to $588 \pm 60{ }^{14} \mathrm{C}$ yr BP and calibrated to $1300-1450 \mathrm{CE}$ and a linear sedimentation rate model between this date and the present to draw conclusions. According to these authors, the replacement of palm pollen by nonpalm pollen coincided with the obtained date, which was 1300-1450 CE. The synchronous arrival of some Neotropical sponges, diatoms and chrysophytes occurred shortly before this date, and Dumont et al. (1998) attributed this to the arrival of Amerindians to the island long before European contact. These authors speculated that the Incas would have arrived to Easter Island and contributed to the cultural collapse by halting the moai industry, which is exactly the opposite of the proposal by Heyerdahl (Heyerdahl \& Ferdon, 1961). Another wave of introductions (cladocera, ostracods, diatoms and chrysophytes), this time of sub-Antarctic and Australian origin, took place between 1527 CE and 1685 CE (interpolated ages) and was linked to the first European visitors.

The most informative paleoecological reconstruction carried out during the transitional phase was performed by Mann et al. (2003), combining island-wide edaphic studies and a sedimentary sequence from Rano Raraku. The frequent presence of palm root casts in buried and truncated soils allowed these authors to identify primeval soils, that is, soils that supported the former forests, across the island (Fig. 14). The age of these primeval soils and, as a consequence, of the former palm forests was estimated by dating the charcoal contained in the sedimentary deposits overlying these soils. None of these dates predated $1200 \mathrm{CE}$, which suggested that primeval soils had not been truncated until this date. In addition, almost all charcoal dates were situated between $1200 \mathrm{CE}$ and $1650 \mathrm{CE}$, which suggested that a major event of island-wide primeval soil truncation occurred during these 450 years, roughly coinciding with the phase of megalithic statue construction (Fig. 15). The presence of abundant charcoal and obsidian flakes (mata'a) in the overlying deposits was interpreted in terms of massive deforestation across the island using slash-and-burn techniques. Using similar edaphic evidence, Mieth et al. (2002) and Mieth \& Bork $(2003,2005)$ dated the beginning of forest clearance on the SW Poike peninsula (Fig. 2) to by $1280 \mathrm{CE}$. A parallel study of a gravity core not identified by Mann et al. (2003) provided some supporting information. Indeed, a sudden increase in sedimentary charcoal occurred at 1070-1280 CE, suggesting massive forest burning. At the same time, magnetic susceptibility abruptly increased and 
sedimentary organic matter sharply declined, which were consistent with enhanced soil erosion and clastic influx to the lake, probably due to vegetation removal and human activities. Mann et al. (2003) concluded that widespread forest clearance began on Easter Island only after $1200 \mathrm{CE}$ and questioned why this deforestation was delayed for centuries after initial settlement, which they situated by $300 \mathrm{CE}$ (Fig. 14). The authors speculated that before $1200 \mathrm{CE}$, the island was occupied, perhaps transiently, by Polynesian hunter-gatherers thriving on its rocky shores. Permanent establishment, dryland farming and population growth might have been initiated by $1200 \mathrm{CE}$, leading to the ecological transformation of the island.

Some biological remains obtained in archaeological sites during this phase were also useful for paleoecological reconstruction. Orliac (2000) and Orliac \& Orliac (1998) analyzed charred pieces of wood from three archaeological sites and identified a number of woody taxa belonging to the $14^{\text {th }}$ to $17^{\text {th }}$ centuries. Only four of these taxa had been identified at the genus level in preanthropogenic pollen records (Triumfetta, Sophora, Coprosma and Paschalococos), whereas the other three were considered to have been introduced by Polynesians (Thespesia, Broussonetia, and Sapindus). However, 10 taxa were of unknown origin and are no longer present on the island. It has been speculated that these taxa were elements of the ancient forests undetected by pollen analysis because of pollen production and dispersal constraints. This seems unlikely, as no pollen grains have been found in any of the numerous Easter Island records obtained to date, including the most recent ones. Another possibility is that these taxa were cultivated by Polynesians for a while and then abandoned. It has also been proposed that the charred wood is actually the remains of drifting wood used by Polynesians for fire. Other useful biological proxies are phytoliths, which were first studied on Easter Island by Cummings (1998). The study of phytoliths at some archaeological sites provided evidence on the surrounding vegetation. Palmae phytoliths were dominant in all samples analyzed, indicating the prevalence of palms in the local vegetation at some time. The samples were not dated, but the archaeological context suggested that some samples could correspond to the periods 1400-1450 CE and 1300-1700 CE. However, the author warned that palms produce huge amounts of phytoliths in virtually all parts of the plant that are deposited on soils after decomposition of organic plant remains. Therefore, palm phytoliths may be abundant in soils even after the clearing of a palm forest and its replacement by secondary vegetation or crops. Cummings (1998) also demonstrated that the preservation of pollen and starch granules of plants economically important in the Rapanui culture was sufficient to reconstruct cultivation practices.

\subsection{The revival}

The revival phase can be subdivided into two well-differentiated parts. The first part extended between 2005 and 2010 and was characterized by a significant increase in coring activities and the reanalysis of previously obtained cores. The second part (2012-2019) was marked by the publication of analyses of the cores obtained between 2005 and 2009.

\subsubsection{Coring intensification and reanalysis}

During the first part of the revival phase, a total of 20 cores were retrieved, almost half (9) of which were from Rano Raraku, seven of which were from Rano Kao and four of which were obtained in Rano Aroi (Table 1). Some preliminary results of these cores (Azizi \& Flenley, 2008; Gossen, 2007; Sáez et al., 2009), along with some reanalyses of older cores (Mann et al., 2008; Butler \& Flenley, 2010), were published during the same time interval. All these papers corresponded to Rano Raraku and Rano Kao. The preliminary analyses of the unidentified Raraku core retrieved by Mann et al. (2003) in 1998 were completed with palynological analyses to refine the deforestation chronology, as well as to test the potential impact of rats and climatic droughts on forest clearance (Mann et al., 2008). This time, the core was identified as "core \#1", and another core taken only $3 \mathrm{~m}$ away was named "core \#2" (Fig. 8, Table 1). Radiocarbon dating and subsequent calibration revealed the occurrence of a sedimentary gap 
between 4090-4410 cal yr BP and 1180-1290 CE in core 1 and a similar hiatus between 4640-4970 cal yr $\mathrm{BP}$ and $1320-1450 \mathrm{CE}$ in core 2 . The authors suggested that a conspicuous depositional hiatus was present in the Raraku sediments, probably due to a climatic drought or a series of droughts that caused the drying out of the lake, thus interrupting sedimentation for approximately 3000 years, until $830{ }^{14} \mathrm{C} \mathrm{yr}$ BP (1180-1290 CE), when the lake replenished again. The drought was attributed to a latitudinal shift in the subtropical storm track (Fig. 3), which controls the intensity and frequency of cyclonic storms, and corresponding changes in the moisture balance on Easter Island. This was the first local and independent evidence for prehistoric climate change on Easter Island. Pollen analysis of the same core recorded forest clearing at Raraku, but this was not considered to have been caused by the mentioned climatic drought, as palm decline began just after the hiatus. Before this sedimentary gap, the vegetation was totally dominated by palm forests, with sedges likely growing locally in the floating mat. The situation was similar just after the hiatus but shortly after palms declined abruptly, whereas herbs such as grasses, sedges, Polygonum and Solanum assumed predominance. This striking vegetation change coincided with an abrupt rise in sedimentary charcoal and with the already mentioned sharp increase in magnetic susceptibility and the abrupt impoverishment of sedimentary organic matter (Fig. 16). Mann et al. (2008) also noted the chronological coincidence of forest clearing, as observed in the Raraku core, with their former study of primeval soils, whose erosion and further burial began by 1200 CE (Fig. 15). These authors concluded that the agricultural colonization of Easter Island occurred in 1200 CE and was accompanied by rapid and widespread deforestation. Mann et al. (2008) pointed out that environmental transformation was very rapid and that the existing stratigraphic records were probably too coarse to document the process, especially during the last 500 years. These authors recommended higher-resolution studies to clarify the timing and patterns of the deforestation process, as well as the potential influence of eventual droughts occurring after the depositional hiatus (1180-1290 CE onwards).

The occurrence of an extensive depositional gap across Rano Raraku sediments was confirmed by a further systematic study based on a transect of eight new cores (RAR01 to RAR08) retrieved in 2006, combined with those from older studies (Fig. 8, Table 1) (Sáez et al., 2009). The sedimentary gap was first noticed in a composite section using the combination of four cores and then recognized across the whole transect as a conspicuous and widespread erosional unconformity between sedimentary units 3 (peats deposited in a Scirpus-rich swamp) and 4 (more clastic sediments deposited after recent lake refilling) (Fig. 17). The temporal extent of this sedimentary gap varied between approximately 5.8-4.2 cal kyr BP and 1100-1450 CE. Sáez et al. (2009) related this hiatus to the mid-Holocene aridity crisis documented elsewhere in the circum-Pacific area as a consequence of an insolation minimum leading to the weakening of the summer monsoon or, in agreement with Mann et al. (2008), the southern shift of storm tracks forced by El Niño-like dominant conditions in the South Pacific. Sáez et al. (2009) noted that the drought ended during the Medieval Climate Anomaly (MCA), which was followed by a wetter phase, as suggested by the replenishment of the lake, coinciding with the onset of the Little Ice Age (LIA). These authors used the argument of Nunn (2000) and Nunn \& Britton (2001) that Easter Island would have been colonized during the MCA, when warm climates and higher sea levels would have favored Polynesian navigation. Therefore, Polynesian settlement and deforestation of Easter Island could have started before $1100 \mathrm{CE}$, during the mid-late Holocene drought, for which there is no sedimentary record (Sáez et al., 2009).

In 2005, a new Rano Kao core (KAO05-3A) (Fig. 8; Table 1) was retrieved to record moisture variations and their potential influence on palm forest disappearance (Gossen, 2007). Radiocarbon dating was based solely on Scirpus californicus (totora) seeds, and the age-depth model showed a chronological coherency that contrasted with the findings of previous studies on Rano Kao sediments (Butler \& Fleney, 2001; Butler et al., 2004). This suggested that totora seeds were likely the best material for radiocarbon dating of Rano Kao sediments. A sharp increase in magnetic susceptibility was recorded by Gossen (2007) in the uppermost part of the bottom sediment, slightly below a radiocarbon date of 650-720 CE. 
This event was followed by a significant increase in sedimentation rates, which was interpreted as a sudden increase in soil erosion, possibly linked to deforestation. Further paleoclimatic and paleoecological studies were performed on core KAO05-3A using a variety of techniques, including pollen analysis (Gossen, 2011). Unfortunately, to the knowledge of the author, this work remains unpublished. Butler \& Flenley (2010) resumed the analysis of their KAO2 core, with the aim of improving the age-depth model hitherto available using only totora seeds/fruits. The model was significantly improved, and a time-ordered paleoecological interpretation was attempted using pollen analysis. The first reliable evidence of forest disturbance was observed between 50 and $100 \mathrm{CE}$, when palm-tree forest was drastically reduced and replaced by grasses and ferns (Fig. 18). This occurred after a conspicuous fire event, and Butler \& Flenley (2010) speculated that this deforestation was caused by fires of volcanic, climatic or anthropogenic origin. Forests partially recovered between 100 and $950 \mathrm{CE}$, probably due to an increase in precipitation, and experienced a further retreat at the end of the zone, which was also linked to a fire event. The presence of Urticaceae/Moraceae pollen was interpreted in terms of paper mulberry (Broussonetia papyrifera) cultivation. Further forest recovery was recorded between 950 and $1350 \mathrm{CE}$, probably due to the migration of human populations out of the Kao crater. The major phase of final deforestation took place between 1350 and $1800 \mathrm{CE}$, clearly associated with an abrupt and extended increase in fire. Paper mulberry cultivation continued. The final extinction of palm trees would have occurred by 1800 CE. For Butler \& Flenley (2010), the most interesting feature of the KAO2 diagram was the possibility that human disturbance began at approximately $100 \mathrm{CE}$ and continued thereafter, perhaps varying in intensity but never ceasing. According to these authors, this interpretation contradicts most archaeological reconstructions, and more research is needed for a sound assessment.

Soil investigations also provided relevant information on Easter Island's prehistory during the first part of the revival phase. Mieth \& Bork (2010) extended their edaphological studies initiated on the Poike peninsula (Mieth et al., 2002; Mieth \& Bork, 2003, 2005) to different parts of the island with the aim of testing the hypotheses of humans, climate or rats as the main deforestation agents. Using the density and distribution of palm root casts in primeval soils, these authors estimated that approximately 16 million palm trees once grew on the island, covering approximately $70 \%$ of its surface, with few palms growing above a $250 \mathrm{~m}$ elevation in the Terevaka highs. The same authors later extended their estimates to 20 million palms covering $80 \%$ of the island (Mieth \& Bork, 2015,2017). Similar to Mann et al. (2003), Mieth \& Bork (2010) found evidence of slash-and-burn activity in extended charcoal layers, often containing charred palm nutshells, situated above the level of the uppermost palm root casts (Fig. 14). Radiocarbon dating of this charcoal at different locations on the island yielded dates of $1200 \mathrm{CE}$ and $1500 \mathrm{CE}$ for the beginning and the end, respectively, of intensive slash-and-burn practices across the island, which is also in agreement with the findings of previous studies by Mann et al. (2003) using similar techniques. Remains of human activity and stone constructions were found directly on top of burned surfaces, supporting extensive anthropogenic forest clearing. Mieth \& Bork (2010) found evidence of palm woodland regeneration on the inner slopes of the Raraku crater by finding traces of palm root casts of a second generation of younger palms in the colluvial layers that covered the truncated primeval soils. This forest regrowth was interrupted by a second deforestation event that occurred by 1402-1436 CE and totally removed the palm woodland from the site. The authors also found that less than $10 \%$ of the charred palm nuts showed teeth marks from rats and concluded that these animals played a minor role in inhibiting forest regeneration but were not the main deforestation agent, as previously suggested by Hunt $(2006,2007)$. Mieth \& Bork $(2010)$ concluded that the islandwide forest clearing was exclusively human-driven. Pollen, phytolith and starch analysis of some archaeological sites demonstrated the joint occurrence of altered forests and crops of bottle gourd (Lagenaria siceraria), yam (Dioscorea alata), sweet potato (Ipomoea batatas) and taro (Colocasia esculenta) before deforestation, which occurred at approximately 1300 CE (Wozniak et al. 2007; Horrocks \& Wozniak, 2008). 


\subsubsection{Publication resurgence}

During the second part of the revival phase (2010-2020), the renewed coring efforts of the 2005-2009 period began to bear fruit in the form of papers reconstructing the main paleoecological trends of the last millennia, using mainly pollen analysis but also a variety of physicochemical proxies that provided independent evidence for climatic and environmental changes. This phase has been subdivided into two main conceptual categories, according to the aims of paleoecological studies. The first category encompasses studies based on biological analyses (notably pollen, phytoliths and starch) of cores from the three ranos and an island-wide soil survey focused on the reconstruction of prehistoric cropping activity. The second category includes multiproxy (physical, chemical and biological) studies on continuous (mostly gap-free) cores from the same waterbodies, aimed at reconstructing the spatiotemporal deforestation patterns and their potential climatic and/or anthropogenic drivers.

Horrocks et al. (2012b) used pollen, phytolith and starch analysis of Easter Island lake sediments for the first time and tested a new method based on Fourier transform infrared spectroscopy (FTIR) to identify degraded starch particles in sediments. These analyses were performed along a transect of four cores (2 to 5) retrieved along the SW margin of Rano Kao, just below the ceremonial village of Orongo (Fig. 8, Table 1), the center of the Birdman cult. The results obtained suggested common terracing for gardening and dwelling within the crater. Albeit using totora fruit/seeds, radiocarbon dating of the four cores showed, once more, frequent age inversions, which prevented the attainment of a reliable chronology. According to Horrocks et al. (2012b), this chronological disorder was due to sediment mixing as a result of human activity. In spite of this, microfossil analysis was successful, and as previously reported for some archaeological sites (Horrocks \& Wozniak, 2008), the scenario was consistent with a landscape of large-scale deforestation (as recorded by phytoliths) and a mixed-crop production system including common Polynesian cultigens such as paper mulberry, taro, yam, sweet potato, bottle gourd and banana (Musa sp.), which were identified mainly from starch remains. This study demonstrated that the SW margin of Lake Kao was an actively cultivated area during and after its deforestation, likely favored by the continuous availability of water and protection from dominant winds (Horrocks et al., 2012b).

A further core, called 1 and located in a less marginal position (Fig. 8, Table 1), was studied further by the same research team (Horrocks et al., 2013). A significant sedimentary gap existed between approximately 12,000 cal yr BP and $3500 \mathrm{cal} \mathrm{yr} \mathrm{BP,} \mathrm{but} \mathrm{the} \mathrm{age-depth} \mathrm{model} \mathrm{was} \mathrm{consistent} \mathrm{between}$ approximately 3500 and 1000 cal yr BP. However, the last millennium, which is the main period of interest for resolving prehistorical developments and was represented in the floating mat, was difficult to interpret because of the lack of a reliable chronology due to multiple age inversions (Fig. 19). A surprising finding was the very high concentration of charcoal fragments and the presence of introduced Musa (banana) phytoliths at the base of the Late Holocene diagram, between approximately 1730 and 910 BCE. According to Horrocks et al. (2013), this could be indicative of an erosion event as a result of forest clearance by fire and associated agriculture, but this would have occurred roughly a couple of millennia prior to the generally accepted dates of settlement of Eastern Polynesia. After a short charcoal-free interval, a second charcoal peak was recorded at 1110 to $800 \mathrm{BCE}$, also coinciding with the presence of banana phytoliths, which reinforced former observations. In this case, a tall peak of Triumfetta at the expense of palms (Arecaceae) was interpreted as a successional response or cultivation of Triumfetta for rope manufacturing (Horrocks et al., 2013). A third possible Polynesian arrival event was recorded at 661-771 CE, which was more consistent with the dates generally accepted for Easter Island settlement. This event was characterized by a sharp decline in Arecaceae, a significant peak in Poaceae and the presence of some charcoal. Despite inconsistent dating, the floating mat showed clear evidence of major landscape disturbance by people, from $4 \mathrm{~m}$ to the top of the core (Horrocks et al., 2013). The disappearance of palms, Asteraceae and Triumfetta along with the large amounts of charcoal, which indicated large-scale clearance of the remaining forests by fire, is notable. 
This paper is a non-peer reviewed EarthArXiv preprint

The same research team developed extensive studies within the Rano Raraku crater aimed at unraveling whether the site was used as a moai quarry alone or was also cultivated (Horrocks et al., 2012a). For this, the authors analyzed macrofossils of dryland plants and conducted combined microfossil analysis (pollen, phytoliths and starch) of a lake core and the surrounding dryland soils. The finding of a consistent alignment of mineralized (iron oxide) root casts attributed to Scirpus californicus some $10 \mathrm{~m}$ above the present lake level was remarkable, as it suggested that the floating mat, and therefore the water level, was $10 \mathrm{~m}$ above the present location sometime in the past. This represented the maximum flooding possible for the Raraku catchment, which probably overflowed on its SW side. The authors suggested that this could have occurred prior to 28,000 cal yr BP when, according to Sáez et al. (2009), Lake Raraku attained water levels much higher than those observed today. An unnamed sediment core, tentatively designed here as "Lake", obtained on the eastern side of the lake (Fig. 8, Table 1) contained several age inversions and a sedimentary gap of approximately 8000 years (10,179-9787 to $1862-1635$ cal yr BP) (Fig. 19), which was much more extensive than those reported by Mann et al. (2008) and Sáez et al. (2009). Horrocks et al. (2012a) argued that this may have been due to the location of the coring site near the shore (Fig. 3.6), where the danger of aerial exposure and the resulting erosion is higher than in other, more central localities. In this case, the replacement of palm forests by grass meadows took place in an apparently abrupt manner at 1325-1437 CE, coinciding with significant fire exacerbation and the first appearance of starch from sweet potato (Ipomoea batatas) and taro (Colocasia esculenta). The subsequent increase in Sophora could have been due to its ability to fill gaps during forest clearance, and its sudden decline after 1401-1437 CE was interpreted as the point of almost complete deforestation (Horrocks et al., 2012a). The dryland soil profile, whose basal date was 776 to $900 \mathrm{CE}$, was totally dominated by grasses and was interpreted as a postclearing unit, which is in conflict with the date of deforestation measured in the lake core. The authors suggested that the soil profile was the result of episodic deposition of soils eroded from upslope and contained strata with carbon older than the onset of anthropogenic deforestation. Palm phytoliths were also abundant in the central part of the soil profile, corresponding to a time when palms were no longer growing at the site. The explanation provided by Cummings (1998) in her pioneering phytolith studies could be invoked here. Indeed, palm phytoliths may be abundant even after deforestation, as they concentrate in soils via the decay of the organic parts of dead palms. Horrocks et al. (2012a) concluded that the Rano Raraku catchment and its surroundings were used not only as a moai quarry but also as an extensive multicropping site and suggested that the crater was intensively gardened and terraced, possibly during the peak of the moaiquarrying period.

Horrocks et al. (2015) also cored Rano Aroi (core RA) and a nearby small depression called Rano Aroi Iti (core RAI) (Fig. 8, Table 1). They also studied some surrounding soil profiles from terraces and dry deposition sites, as well as a cave. The main aim of this study was to evaluate the timing and nature of deforestation and agricultural activity at the highest elevations of the island and compare them with those at lowland sites. The study was focused on the last millennium and included pollen, phytoliths, starch and two new proxies: diatoms and arthropods. The resulting age-depth model for core RA was poorly constrained from 12,000 to $1000 \mathrm{cal} \mathrm{yr} \mathrm{BP}$, and a set of dates were rejected as older and younger than expected, probably due to hydrological movements of macrofossils, coring contamination, overturning of floating mats or volcanic $\mathrm{CO}_{2}$ influence (Horrocks et al., 2015). The model was well constrained for the upper $1.2 \mathrm{~m}$, containing the last $1500 \mathrm{cal}$ yr BP, and was therefore appropriate for analyzing evidence associated with human activity. The Rano Aroi Iti core (RAI) contained a record of the last 1500 years at a depth of approximately $2 \mathrm{~m}$. According to Horrocks et al. (2015), the sudden increase in charcoal and the total disappearance of pollen of Arecaceae (Fig. 19) clearly reflected largescale anthropogenic deforestation by burning. This event commenced at 1153-1305 CE. Total forest clearance at Rano Aroi occurred shortly thereafter, between 1522 and $1773 \mathrm{CE}$. The top $0.6 \mathrm{~m}$ of the core corresponded to the postcontact period and reflected modern agroforestry (Pinus and Myrtaceae), as well as the formation of the modern swamp vegetation, which was dominated by Scirpus and 
Polygonum. An interesting finding was the presence, just before total deforestation, of pollen from Sisyrinchium, probably S. michrantum, an invasive American weed widely naturalized elsewhere. In core RA, this pollen type was present in a single sample, but in core RAI, Sisyrinchium occurred in a consistent manner in all almost all samples examined, since at least 408-634 CE. The authors mentioned a previous finding by Cañellas-Boltà et al. (2012) in Rano Raraku that could suggest early Amerindian contact long after Polynesian arrival. Other possibilities suggested by Horrocks et al. (2015) are that Rano Aroi Iti had been disturbed to its full depth, thus giving ages older than expected, or that the whole sequence was formed after European contact. Evidence for horticultural activity was limited in the swamp cores, as only a few starch grains of cf. Colocasia esculenta were found in a few samples of core RA. Some terraces and the cave provide additional evidence in the form of phytoliths of Musa and cf. Broussonetia (Horrocks et al., 2015). These authors noted that the evidence of horticulture was similar to that identified at lowland sites (Horrocks et al., 2012a, b, 3013), except for the lack of remains of Ipomoea batatas in Rano Aroi, where it seems not to have been an important local cultigen. According to some radiocarbon dates from the cave and a terrace, the authors suggested that agricultural activity in Rano Aroi took place either between 1670 and 1740 CE or between 1795 and the introduction of sheep farming. In either case, Rano Aroi seems to have been occupied by humans in a more or less continuous fashion later than lowland sites (Rao Kao and Rano Raraku).

The study of prehistoric agricultural activities using microfossils (pollen, starch and phytoliths) was completed with an extensive survey of dryland soils across the island carried out by the same team (Horrocks et al., 2016), aimed at determining the success and extent of past Easter Island's agriculture. Of the 11 sites analyzed ( 15 soil profiles and 40 samples in total), only one soil profile was dated. The two dates obtained were "modern" at 5-10 cm and 6-215 CE at 60-65 cm. The authors considered the last presettlement date to be older than expected because of the remobilization of plant material as a result of human activities. They also inferred that other profiles broadly followed the same stratigraphic patterns and considered that the environments sampled corresponded to times after Polynesian settlement. These analyses confirmed that the Polynesian cultigens previously identified in the three freshwater catchments (Rano Aroi, Rano Kao and Rano Raraku) and some archaeological sites were cultivated across most of the island. Horrocks et al. (2016) identified Broussonetia papyrifera (paper mulberry), a species used by the ancient Rapanui to make bark clothing, using pollen and phytoliths. This taxon was found at $45 \%$ of the sites, including those at higher elevations on the island. Musa (banana) phytoliths were found at only one site. The fruit of this plant was used for human consumption, and the leaves were utilized for house covering and tying purposes in house and garden construction. The identification of Ipomoea batatas (sweet potato) starch was problematic because of its similarity with the starch of other cultivated species and the indigenous species Ipomoea pes-caprae. Horrocks et al. (2016) considered the starch found in $36 \%$ of dryland soils to correspond to sweet potato. Pollen and starch grains of Colocasia esculenta (taro) were found at $55 \%$ of the sites, including high-elevation localities.

The second category of paleoecological studies was focused on the study of continuous and chronologically coherent - i.e., free from large sedimentary gaps and age inversions - records of the last millennia using a multiproxy approach with biological and nonbiological proxies able to provide independent paleoclimatic and paleoecological reconstructions, thus avoiding circularity. This was possible for cores RAR08 (Rano Raraku), ARO08-02 (Rano Aroi) and KAO08-03 (Rano Kao) (Fig. 20). See also Fig. 8 and Table 1 for the locations of the cores and their main features.

The Raraku core (RAR08) included the last five millennia (Fig. 21), which were mostly missing in former works (Flenley et al., 1991; Dumont et al., 1998; Mann et al., 2008; Sáez et al., 2009) due to extensive millennial-scale depositional gaps. In this core, only two minor sedimentary gaps were detected, the first between approximately $500 \mathrm{CE}$ and $1165 \mathrm{CE}$ (665 year duration) and the second between $1570 \mathrm{CE}$ and 1720 CE (150 year duration), which were interpreted as consequences of depositional cessation and/or 
increased erosion during dry phases (droughts) that likely resulted in the total drying out of the lake (Cañellas-Boltà et al., 2013). The first drought ended during the MCA, and the second dry phase took place during the LIA. The pollen record showed that, contrary to former interpretations, deforestation did not occur in an abrupt manner. Rather, palm forest decline was gradual, with three main decline pulses at $450 \mathrm{BCE}, 1200 \mathrm{CE}$ and $1475 \mathrm{CE}$. The first deforestation pulse (450 BCE) was accompanied by an increase in grasses and the first appearance of Verbena litoralis, coinciding with an increase in charcoal. This constituted the first palynological record of $V$. litoralis in Easter Island sediments (Fig. 22). An interesting aspect of this finding is that $V$. litoralis, a native to tropical America that is commonly associated with anthropogenically disturbed sites (agricultural or ruderal), had previously been considered a species introduced to Easter Island after European contact (Zizka, 1991). Cañellas-Boltà et al. (2013) discussed whether the early arrival of Verbena and its successful establishment on Easter Island could have been the results of chance long-distance dispersal or human arrival much earlier than formerly expected. According to the authors, the coincidence of the settlement of Verbena with the first palm decline and the first charcoal increase supported the second option, which would involve the human discovery of Easter Island some 1500 years before the generally accepted date. It is also interesting to note that the first deforestation pulse occurred when the catchment was occupied by a mire instead of a lake, as indicated by the peaty sediments and the dominance of benthic diatoms, along with the absence of planktic species (Fig. 21). This suggested that climates were drier than at present but not arid.

The second deforestation pulse, occurring shortly before $1200 \mathrm{CE}$, represented a major ecological disturbance characterized by a significant forest decline and an extensive expansion of grass meadows as well as Verbena populations (Fig. 21). The abrupt increase in charcoal suggested that these events were linked to remarkable fire exacerbation, likely of anthropogenic origin. These changes coincided with a shift in diatom assemblages from benthic to planktonic, which suggested a change from mire to lacustrine environments, likely due to the return of wetter climates after the MCA drought. The acceleration of fire and forest clearing in such wetter climates reinforces that humans would have been the main factor responsible for landscape disturbance. The third forest clearing event (1475 CE) represented the total deforestation of the Raraku catchment and the irreversible establishment of grass meadows, also associated with a significant charcoal increase. Of the three recorded palm declines, only the second could possibly be linked to climate change, as it occurred immediately after the first drought inferred from the depositional gap recorded between 500 CE and 1200 CE. Cañellas-Boltà et al. (2013) suggested that climate and human activities could have acted synergistically to drive the demise of forests. According to these authors, drought would have favored vegetation ignitability, thus facilitating forest burning. After the LIA drought, planktic diatom assemblages dominated, and benthic species were absent, suggesting maximum lake levels and wetter climates.

The Rano Aroi core (ARO08-02) provided a continuous record of the last 2600 years, with the exception of the last two centuries (Rull et al., 2015). Four main vegetation phases could be distinguished (Fig. 23). During Phase I ( $750 \mathrm{CE}$ to $1250 \mathrm{CE}$ ), the site was covered by palm woodland with Asteraceae shrubs in the understory within a regional landscape dominated by grass meadows. Semiaquatic plants typical of present-day swamp vegetation (Cyperaceae and Polygonum) and ferns were absent, suggesting that the swamp was dry or the water level was lower than it is today. Despite the general uniformity of this phase, a recurrent pattern emerged in the form of successive palm, Asteraceae and grass peaks likely representing processes of landscape opening (LO) from palm-dominated to grass-dominated landscapes. The first of these events (LO1) occurred between $300 \mathrm{BCE}$ and $50 \mathrm{CE}$, and the second (LO2) occurred between $600 \mathrm{CE}$ and $1100 \mathrm{CE}$. Between $1250 \mathrm{CE}$ and $1520 \mathrm{CE}$ (Phase II), progressive densification of palm woodland to more-closed forests took place, along with a change in the shrubby understory, where Sophora coexisted with Asteraceae. At the same time, the local semiaquatic vegetation appeared, which indicated an increase in the water table, probably due to wetter climates, which would have favored forest growth. During Phase III (1520 CE to $1620 \mathrm{CE}$ ), palm forests and the associated shrublands 
were abruptly removed and replaced by grass meadows, coinciding with a sudden charcoal increase, which suggested anthropogenic burning. The palynological expression of this deforestation event (LO3) was similar to that of the former LO1 and LO2 events but was significantly faster and more direct, from palms to grasses without an intermediate shrub stage. Present-day vegetation, consisting of a continuous cover of grass meadows with no signs of the former forests and shrublands, was established after 1620 CE (Phase IV). Notably, the charcoal peak occurred during this phase, when woody elements no longer grew. The coincidence of the charcoal peak with the decline in semiaquatic plants and ferns is compatible with the burning of local swamp vegetation.

Some geochemical proxies underwent relevant shifts during LO1 and LO2 events in the form of significant $\mathrm{C} / \mathrm{N}$ declines (due to $\mathrm{N}$ increases) linked to conspicuous increases in $\delta^{15} \mathrm{~N}$ and $\delta^{13} \mathrm{C}$ (Fig. 22). The increase in $\mathrm{C} / \mathrm{N}$ coupled with a decrease in $\delta^{15} \mathrm{~N}$ is compatible with lower water levels and eventual drying (Houlton \& Bai, 2009; McLauchlan et al., 2013). The increase in $\delta^{13} \mathrm{C}$ could be due, in part, to the general increase in $C_{4}$ grasses to the detriment of woody $C_{3}$ plants and algae (O'Leary, 1988). Therefore, the geochemical signal is consistent with the occurrence of dry climates during the LO1 and LO2 events. The LO3 event was more difficult to interpret in climatic terms, as humans were likely involved in forest clearing. However, geochemical proxies showed a trend similar to that observed in the lower half of LO1 and LO2, suggesting the initiation of a shift to drier climates (Rull et al., 2015). Interestingly, event LO2 (600-110 CE) was roughly coeval with the MCA Raraku drought (500-1165 CE), and event LO3 (1520$1700 \mathrm{CE}$ ) occurred at a similar time as the LIA Raraku drought (1570-1720 CE). This coincidence suggested the occurrence of generalized dry climates across Easter Island, although they were more intense in the lowlands (Raraku), where they caused the interruption of sedimentation. It is possible that the increasing precipitation gradient with increasing elevation attenuated the drought intensity in Aroi, where vegetation changes but no drying out were recorded.

The Rano Kao core (KAO08-03) recorded a time interval between approximately $950 \mathrm{CE}$ and $1710 \mathrm{CE}$ (Seco et al., 2019). The analysis of this core is still in progress to increase the resolution, but the main vegetation trends over time have already been resolved. The novelty of this analysis with respect to former studies of Easter Island sediments was the identification of fungal spores linked to human activities, with an emphasis on Sporormiella, a genus of coprophilous fungi growing in the dung of domestic vertebrates and, therefore, an indicator of human presence (Van Geel et al., 2003). According to Seco et al. (2019), the Kao catchment was covered by an open palm woodland rather than a closed palm forest at approximately $1000 \mathrm{CE}$, which suggested that the Kao forests were already being disturbed. From that point, the deforestation was gradual but spiked by three acceleration pulses at approximately $1070 \mathrm{CE}, 1410 \mathrm{CE}$ and $1600 \mathrm{CE}$ (Fig. 24). Each of these pulses was followed by a regeneration trend, which supported the findings of Mieth \& Bork (2010) regarding forest regeneration, except the third, after which the forests no longer recovered. The first pulse of forest decline (1070 CE) occurred during the MCA drought recorded at Rano Raraku and Rano Aroi, which suggested an influence of climate. A brief charcoal peak between approximately 1150 CE and 1200 CE did not affect forest regeneration, possibly favored by wetter climates. The second forest decline (1410 CE) coincided with another charcoal peak and the first continuous appearance of Sporormiella spores, suggesting the onset of continuous anthropogenic disturbance. Palms almost disappeared but slightly recovered until the third decline pulse (1600 CE), when charcoal and Sporormiella dramatically increased, roughly coinciding with the first phases of the LIA drought, which could have contributed to fire exacerbation. A general conclusion was that humans were present in the Rano Kao catchment since the beginning of the record but in dispersed or occasional populations. Human presence became more or less permanent, but still scarce, by $1410 \mathrm{CE}$. The catchment was fully deforested and totally disturbed by larger human populations by $1600 \mathrm{CE}$, coinciding with the foundation of the ceremonial village of Orongo, the center of the Birdman cult (Robinson \& Stevenson, 2017). At the same time, the pollen of an Apiaceae species, likely belonging to Apium, increased abruptly and remained constant until at least $1700 \mathrm{CE}$, which 
suggested the cultivation of this plant, as already proposed by Flenley et al. (1991) in their pioneering studies.

\section{Discussion}

\subsection{Discovery and settlement}

Several paleoecological studies have suggested or supported the possibility of an early discovery of Easter Island before the accepted Polynesian settlement occurred between 800 CE and 1200 CE. The first well-dated evidence of deforestation and meadow expansion was found in Rano Kao sediments (core KAO2) and dated between $50 \mathrm{CE}$ and $100 \mathrm{CE}$ (Butler and Flenley 2010). The coincidence of this forest clearing event with a conspicuous charcoal increase (Fig. 18) suggested that humans could have been involved. These authors noted that this would be contrary to most archaeological reconstructions and discussed other possibilities for the origin of fire, such as spontaneous combustion, a combination of lightning and dry climates, and volcanic eruptions. They argued that lightning is rare on Pacific islands and is always accompanied by heavy rainstorms (Doswell, 2002), which discourages fire, and that there is no evidence of volcanic eruptions by 50-100 CE (González Ferrán et al., 2004). Butler \& Flenley (2010) also emphasized that charcoal concentrations never returned to background levels after the 50-100 CE exacerbation, suggesting continuous disturbance. In addition, they argued that, according to linguistic evidence, human arrival to Easter Island would have occurred by $100 \mathrm{CE}$ (Flenley \& Bahn, 2003). The conclusion was that further evidence was needed for a sound interpretation of the available evidence, which could not be dismissed. Also in Rano Kao (Core 1), Horrocks et al. (2013) found a high concentration of charcoal fragments associated with Musa phytoliths in sediments corresponding to 1730-910 BCE (Fig. 19). According to these authors, this result could be interpreted in terms of anthropogenic forest clearing by fire and associated agriculture, but the dates were confusing, as they were much older than the expected settlement of Eastern Polynesia (Kirch et al., 2010; Wilmshurst et al., 2011). Indeed, according to the more accepted chronological framework, Polynesians could have been colonizing the Central Pacific archipelagos by that time (1730-910 BCE) (Fig. 10). In this case, Horrocks et al. (2013) did not dismiss the existence of dating problems due to contamination, although they maintained the robustness of their age-depth model. These Kao records did not have clear indications of human presence, but others from Raraku and Aroi were more specific in this sense.

A well-dated record of possible human presence on Easter Island earlier than expected was obtained by Cañellas-Boltà et al. (2013) in Rano Raraku (core RAR08). The pollen signal was the same as that in Rano Kao - that is, an event of forest decline and meadow expansion associated with a charcoal increase but this time combined with a new element, the pollen of Verbena litoralis (Figs. 21 and 22), an anthropochorous weed of American origin (Zizka, 1991). This plant - locally known as puringa - is now widespread all over the island, from the coasts to the highest elevations, and until recently, it was thought to have been introduced shortly before 1870 CE (Zizka, 1991). However, the Raraku record showed that the species was present since at least $450 \mathrm{BCE}$, coinciding with the first deforestation pulse (Fig. 21). Cañellas-Boltà et al. (2013) discussed whether V. litoralis could have reached Easter Island by long-distance dispersal or by human introduction. The coincidence of forest demise, meadow expansion and fire with the presence of this anthropochorous weed with well-known relationships with human activities suggested that humans introduced $V$. litoralis to Easter Island by 450 BCE, at least 1500 years before the expected Polynesian settlement. At the beginning, forest disturbance was minimal, and Verbena was scarce, but by $1200 \mathrm{CE}$, forest clearance underwent an abrupt acceleration coinciding with fire exacerbation and a conspicuous expansion of grasses and Verbena. Cañellas-Boltà et al. (2013) suggested that the first forest disturbance and the introduction of Verbena were caused by small human populations and that the further forest decline and the expansion of grasses and Verbena were the results of population growth and the increased use of the Raraku catchment by humans. 
Not only the settlement timing but also the origin of the first settlers is challenged by the Raraku record. Indeed, if the American Verbena was carried by humans in $450 \mathrm{BCE}$, the most likely mechanism would have been direct transport from America by Amerindian people. In summary, Native Americans could have visited Easter Island long before Polynesian arrival. Unfortunately, the sedimentary gap between 500 and 1165 CE (Cañellas-Boltà et al., 2013) prevents us from knowing whether Amerindian presence was continuous until Polynesian arrival and whether these cultures interacted. However, times before $500 \mathrm{CE}$ show continuity of grasses, Verbena and fires, which suggests maintained but low-intensity disturbance, with forests remaining virtually untouched. In summary, contrary to the assertion of Flenly \& Bahn (2003) that Easter Island was settled only once by Polynesians during the last millennium, the finding of Verbena suggests that the island had already been discovered, albeit probably not fully settled, by Amerindians by 450 BCE. The whole picture is consistent with the idea of Mann et al. (2003) of small, scattered and perhaps transient human populations of hunter-gatherers with low-impact practices until $1200 \mathrm{CE}$, when full island disturbance commenced. The novelty here is that Native Americans could have been part of these ephemeral and/or intermittent societies and that the plant they introduced was adopted by Polynesians and became part of their culture. It has also been suggested that the arrival of Verbena to Easter Island might have been by back-and-forth mechanisms, as occurred with the sweet potato, which implies that Polynesians arrived first to America and then to Easter Island (review in Rull, 2019). The fact that these initial discoverers and/or settlers did not leave terrestrial archaeological evidence might be due to the paucity and ephemerality of their settlements, along with the effect of evidence clearing by natural and/or anthropogenic agents (Stevenson et al., 2000; Flenley \& Bahn, 2011). On other oceanic islands, it has been demonstrated that lake sediments may preserve evidence for human presence - e.g., discovery without settlement or ephemeral/intermittent settlement - prior to permanent establishment (Rull et al., 2017; De Boer et al., 2019).

The pollen of another American invader taxon, Sisyrinchium (Iridaceae), was found in the sediments of Rano Aroi (cores RA and RAI) by Horrocks et al. (2015) and dated to long before Polynesian colonization. The presence of this pollen was consistent in all samples of the RAI core since at least 410-630 CE. Again, these authors maintained the robustness of their age-depth model and considered this plant to have been introduced by humans several centuries before the accepted ages for Polynesian colonization. However, Horrocks et al. (2015) are very cautious and argue that "...we report this evidence and note that there is no clear reason to dismiss it, nor there is a clear case to accept it. Specifically, we are unaware of any Rapa Nui archaeological excavations or other evidence that provide conclusive support for prehistoric Amerindian presence". However, it seems clear that the case of Sisyrinchium is compatible with that of Verbena and the above comments on the Amerindian presence on Easter Island. The added value in this case is that the RAI core includes the time interval hidden by a sedimentary gap in the Raraku core, thus suggesting the continuity of Sisyrinchium during the last 1300-1500 years. This does not mean, however, that Amerindians were present during this whole time, only that the plant established on the island after its initial introduction, as occurred with Verbena.

It seems that novel paleoecological evidence is emerging about the possibility of an early settlement of Easter Island, long before Polynesian arrival, in the form of forest clearing and meadow expansion linked to fire events and accompanied, in some cases, by the introduction of plants of American origin related to human activities. These findings should not be neglected, as they are based on robust age-depth models and reliable taxonomic identification. In some cases, the same authors who recorded these events are overly cautious and seek alternative explanations because their results contradict the accepted archaeological chronologies. However, paleoecological evidence should not be selected according to its agreement or disagreement with current archaeological standards (and vice versa) but should be taken as is, in an objective manner, provided that methodological aspects such as those mentioned above are guaranteed. Therefore, testing the hypothesis of early human presence on Easter Island is a suitable paleoecological aim, whose first steps have already been done and which should be 
enhanced and improved. The coincidence of forest clearing events, fire and the introduction of plants of American origin seems to be a good place to start, which could be improved with the incorporation of direct evidence of human presence using biomarkers such as DNA and specific fecal lipids, among others (e.g., Bull et al., 2002; D’Anjou et al., 2012; Hofreiter et al., 2012; Rawlence et al., 2014; Parducci et al., 2017). The field of biomarker analysis of lake sediments is currently in full swing, and it is hoped that future paleoecological studies on Easter Island can take advantage of this.

\subsection{Climate change}

Paleoecological research on Easter Island has also provided local paleoclimatic information using biotic and abiotic proxies independent from pollen and spores, as demanded by Flenley et al. (1991). This has two main advantages. First, climatic shifts have been documented in situ, which avoids the need to rely on assumptions derived from regional climatic reconstructions and correlations with distant localities, often governed by disparate climatic systems. Second, the use of physicochemical proxies and microfossils other than pollen and spores to reconstruct past climates allows circumventing circular reasoning and makes it possible to study the response of vegetation and the landscape to climate shifts. After these studies, the first observation is that only changes in the moisture balance have been recorded, which supports the early predictions of Flenley et al. (1991) that temperature shifts on Easter Island would have been minor and, therefore, of little ecological significance. Regarding moisture variations, the most relevant findings have been the occurrence of two centennial-scale droughts separated by a phase of wet climates (Fig. 25). The first drought, called the MCA drought, was recorded in Rano Raraku between 500 and 1170 CE, when the lake dried out and remained in this condition for more than six centuries (Cañellas-Boltà et al., 2013). The same drought was recorded at Rano Aroi between 600 and $1100 \mathrm{CE}$ using isotopes (Rull et al., 2015). It is interesting to note that the MCA drought was coeval with the Classic Maya Collapse (ca. $900 \mathrm{CE}$ ), which was attributed to a series of prolonged droughts that led to the final demise of this civilization (Haug et al., 2003). An ensuing moisture increase resulting from a significant water-level rise was recorded between approximately 1170 and 1570 CE at Rano Raraku, as deduced from a conspicuous shift in the diatom flora. The same wetting was observed in Rano Aroi after isotope analysis. This wet phase could have included the questioned 1300 CE event of Nunn $(2000,2007)$ and Nunn \& Britton (2001), characterized by uncommonly heavy precipitation as a consequence of an increase in the El Niño frequency.

The second drought, the LIA drought, occurred between approximately 1570 and 1720 CE, when Lake Raraku dried out again (Fig. 25). In Rano Aroi, this drought was more difficult to detect, probably due to the masking effects of human disturbance beginning in $1520 \mathrm{CE}$. The LIA drought coincided with the socalled " $17^{\text {th }}$ century crisis" in tropical Asia, characterized by droughts, famines and large-scale economic and political disruption (Grove \& Adamson, 2018). This crisis has been related to changes in the variability of the Indian Ocean Dipole (IOD) climatic system affecting ENSO variability in the Pacific Ocean (Abram et al., 2020). Before the intense MCA and LIA droughts, climates were drier than at present (but not arid) in both Raraku and Aroi (Cañellas-Boltà et al., 2013; Rull et al., 2015). After the LIA drought, Lake Raraku attained its present-day levels, which suggested the return of wetter climates. The potential climatic mechanism causing the droughts can be summarized as a southern shift of the humid subtropical storm track and the emplacement of the dry South Pacific Anticyclone (Fig. 3) over Easter Island, likely forced by ENSO fluctuations (Mann et al., 2008; Sáez et al., 2009). There is still much work to do in order to obtain a sound understanding of the recent paleoclimatology of Easter Island, especially in terms of resolution and spatial patterns. At present, the Rano Kao KAO08-03 core (Fig. 24) is being studied for high-resolution paleoclimatic reconstruction using the isotopic composition of plant leaf waxes as precipitation proxies, but other organic biomarkers are available for use as paleoclimatic proxies (Eglington \& Eglington, 2008; Castañeda \& Schouten, 2011). These techniques should also be applied, if possible, to other cores already obtained and other information retrieved in further fieldwork. 
In a recent paper, Margalef et al. (2018) suggested that some major volcanic eruptions that occurred on Pacific islands might have affected regional climatic trends by lowering average temperatures and/or by affecting ENSO variability and, therefore, moisture availability. These authors emphasized the potential effect of two major eruptions that occurred during Easter Island's prehistory, in the Samalas (1257 CE) and Kuwae (1453 CE) volcanoes, the first situated on Indonesian Lombok Island, east of Bali, and the second in the Vanuatu Islands (Fig. 1). Unfortunately, according to the same authors, there is no evidence of these eruptions in the Easter Island sedimentary cores studied to date, and it is difficult to find evidence of the potential influence of regional volcanism on Easter Island's climate. The dates of the mentioned volcanic events are incorporated into Fig. 25 in the hope that future research will be able to test their eventual impact on climatic trends of the island. Notably, both eruptions occurred during the wet phase of rising lake levels between the MCA and LIA droughts.

\subsection{Spatiotemporal deforestation patterns}

It is not unusual to believe that Easter Island's deforestation was a single event across the island with a synchronous and well-defined beginning and end (e.g., Flenley et al., 1991; Mann et al., 2003; Hunt, 2006; Mieth \& Bork, 2010), although the specific dates may vary according to author. However, paleoecological research has shown that forest clearing did not occur at the same time and at the same rate in the Rano Aroi, Rano Kao and Rano Raraku catchments (Rull, 2016a, 2020a). Figs. 26 and 27 clearly show that deforestation was heterogeneous in time and space. The first deforestation pulse during or after Polynesian settlement was detected in Rano Kao to be approximately 1050 CE (Seco et al., 2019). By that time, humans were already present around the lake but at very low numbers that were insufficient to cause the magnitude of the deforestation observed. This deforestation pulse occurred during the MCA drought that dried out Lake Raraku, which suggests a potential influence of climate. Rano Aroi was likely unaffected by the maintenance of enough moisture for palm development thanks to the elevational precipitation gradient, which today is almost $200 \mathrm{~mm} / 100 \mathrm{~m}$ elevation (Puleston et al. 2017). This local deforestation event occurred during the phase of low-intensity forest disturbance proposed by Mieth \& Bork (2015) and more than a century before the dates proposed by the defenders of a late colonization, in 1200 CE or after (Hunt \& Lipo, 2006; Wilmshurst et al., 2011). This could be one more manifestation of human settlement without extensive archaeological expression and/or evidence clearing.

The next deforestation episode occurred in Raraku at approximately $1200 \mathrm{CE}$, just after the MCA drought, under sustained, although moderate, fire pressure (Cañellas-Boltà et al., 2013). The occurrence of wetter climates more favorable for forest growth suggests that this deforestation pulse was of anthropogenic origin. Forest retreat was continuous despite fires not increasing significantly, which suggests the existence of positive feedbacks amplifying forest responses to sustained fire incidence. At the same time, the Kao forests were recovering, likely due to favorable climates and the absence of human pressure, as indicated by the lack of fires and coprophilous fungi (Seco et al., 2019). However, this forest regeneration was interrupted by another deforestation event (1350 CE), likely anthropogenic, coinciding with a charcoal peak and the return of Sporormiella spores (Seco et al., 2019). Rano Aroi continued to be devoid of humans, and the significant forest expansion recorded between approximately 1300 and 1500 CE was likely due to the occurrence of wetter climates (Rull et al., 2015).

Rano Raraku forests disappeared after a final deforestation event by $1450 \mathrm{CE}$, coinciding with significant fire exacerbation supporting human deforestation (Cañellas-Boltà et al., 2013). At the same time, human pressure declined in Rano Kao, and its forests, which had almost removed during the $1350 \mathrm{CE}$ deforestation pulse, experienced a new regeneration trend, although less intense than the former (Seco et al., 2019). At the same time, Rano Aroi was truly forested for the first time, and its forests became the densest and most extensive on the island due to the almost complete deforestation of Raraku and Kao. This forest densification was likely due to wetter climates and the absence of human activities in Rano 
Aroi. However, the situation changed by $1570 \mathrm{CE}$, when a sudden deforestation event completely removed these forests in approximately one century (Rull et al., 2015). This coincided with intense fire exacerbation, suggesting anthropogenic causes; however, the LIA drought would have acted synergistically by favoring forest flammability and preventing regeneration. The last deforestation event on the island irreversibly removed the Kao forests by $1600 \mathrm{CE}$, coinciding with the largest human occupation of this crater, as indicated by the significant increase in fires and Sporormiella spores. This has been associated with the foundation of the ceremonial village of Orongo at the crest of the Kao crater (Robinson \& Stevenson, 2017).

Taken globally, the intensification of deforestation between approximately $1200 \mathrm{CE}$ and the total disappearance of forests by approximately 1600 CE coincides with the phase of increased forest clearing formerly proposed by Mann et al. (2003) and Mieth \& Bork (2015), after a phase of low-intensity ecological impact. However, the detailed reconstruction shown here, based on continuous sedimentary records from the three basins suitable for palaeoecological study, significantly increases the spatiotemporal resolution and provides much more detail on the patterns, processes and possible causes of the different forest removal and regeneration events. Further efforts should emphasize the study of proxies for human presence, such as Sporormiella, and specific molecular biomarkers. The use of paleoclimatic biomarkers and an increase in temporal resolution are also recommended.

\subsection{Cultural inferences}

Paleoecology has also provided direct information on cultural aspects of the ancient Rapanui society, mainly on cultivated plants. In other cases, paleoecological information has been useful for analyzing new cultural scenarios emerging from previously unnoticed events, such as the possible influence of droughts on human affairs. Microfossil analysis of lake sediments and drylands across Easter Island has provided direct evidence of plants cultivated by the ancient Rapanui, as a sample of Polynesian cultivation practices (Table 2). Cultivation was mainly performed on protected manavai, but paleoecology demonstrated that lake-shore terraces were also actively cultivated, possibly using local irrigation techniques, mainly in Rano Kao and Rano Raraku (Horrocks et al., 2012a, b, 2013; Sherwodd et al., 2019), where freshwater was easily accessible. The available evidence indicates that cultivated species were widespread across the island, with no manifestation of crop specialization on drylands and lake terraces. However, it is noteworthy that some species (yam, bottle gourd and sweet potato) were not cultivated in Rano Aroi, which suggests that these cultigens were restricted to lowlands.

Unfortunately, a chronology of ancient Rapanui cultivation still cannot be established because of the already discussed dating difficulties. This would be a very interesting target to pursue. The study of pollen, phytoliths and starch of cultivated plants in continuous and chronologically consistent cores used to unravel deforestation patterns could be a good start, which might be complemented by new coring campaigns along lake shores.

During the MCA and LIA droughts, Rano Raraku was totally dry, and freshwater availability was critical for human life. Polynesians arrived during the MCA drought, when Lake Raraku was dry but its surroundings were still forested. At that time, the only permanent freshwater sources were Lake Kao and the Aroi swamp. Not surprisingly, the Kao forests were the first to be disturbed, probably by small populations arriving to the island. During the wet phase following the MCA drought, Lake Raraku replenished, and the forests around it started to be cleared. This occurred by $1200-1300 \mathrm{CE}$, coinciding with the onset of monumental architecture and the moai cult. The continued deforestation of Rano Kao and Rano Raraku left their forests close to disappearance by 1500-1600 CE, whereas Rano Aroi, still free from human influence, experienced densification likely owing to wet climates.

Under these conditions, the LIA drought and the second drying out of Rano Raraku occurred, which had been deforested since 1450 CE (Cañellas-Boltà et al., 2013). The situation was more critical than that 
during the MCA drought, as the Rapanui population was probably more numerous and Rano Raraku, the center of the moai industry and the core of the Rapanui culture, was a badland devoid of freshwater and forests (Rull, 2020a, b). Again, the only permanent freshwater bodies were Lake Kao and the Aroi swamp (Rull, 2016a), which began to be fully exploited and were totally deforested by 1600 CE. Rano Aroi was abandoned after deforestation, but human activities continued in Rano Kao, leading to the emergence of the Birdman cult and the foundation of its cultural center: the ceremonial village of Orongo (Robinson \& Stevenson, 2017). Additional evidence of human activity include the cultivation of Kao lake margins just below Orongo (Fig. 28). Therefore, anthropogenic deforestation of Rano Raraku (1450 CE) followed by the incoming LIA drought (1570 CE) might have been involved in the shift of the Rapanui cultural center. This supports the former idea of McCall (1993), according to whom the LIA should not be viewed as a decisive (i.e., deterministic) deforestation driver but as a new factor to be considered in the explanation of social and cultural developments. Whether the geographical shift of Easter Island's cultural core from Rano Raraku to Rano Kao was due to population movement or newly acquired superiority of the western clans over the eastern clans, triggered by the deterioration of the ancient moai quarry, remains unknown.

The causes of the shift from the moai cult to the Birdman cult remain controversial, but several reasons may be suggested from the above observations. The first is, obviously, the search for freshwater, but this justifies only the geographical displacement of the cultural core of the Rapanui society. Another argument is that the Kao rocks were not suitable for moai carving. Indeed, the Kao crater is made of hard basalt and is one of the quarries used to obtain the tools used to carve the softer Raraku tuff (Gioncada et al., 2010). As mentioned before, only 13 of the ca. 1000 known moai are made of basalt (Van Tilburg, 1994). Robinson \& Stevenson (2017) suggested that the shift from the moai cut to the Birdman cult was a territorial restructuring in response to soil nutrient depletion in interior lands, probably due to deforestation and a long period of dryness, which is in agreement with paleoecological observations. The combination of these climatic and anthropogenic disturbing factors, however, did not lead to the collapse of the Rapanui society, which was able to maintain a healthy society on the basis of new agricultural developments (Mulrooney, 2013; Mieth \& Bork, 2015, 2017; Stevenson et al., 2015; Jarman et al., 2017; Wozniak, 2017). It has also been proposed that the shift from the moai cult to the Birdman cult was a change from a rigid hierarchical society to a more dynamic sociopolitical organization, which represented a strategy for better adaptation to the new environmental context. In this way, the Rapanui neither collapsed nor disappeared but remained in their home despite the intense environmental pressure, showing exceptional resilience (Rull, 2016a).

An additional freshwater source for the prehistoric Rapanui has been proposed, involving coastal seeps fed by the groundwater system (Brosnan et al., 2018). At present, wells are usually drilled to access coastal groundwaters, whose uppermost layers (less than a meter deep) are fresh, and the salinity increases with depth (Herrera \& Custodio, 2008) (Fig. 5). The ancient Rapanui were unable to drill wells on volcanic rocks and instead excavated pits parallel to the shoreline, called puna, which are still preserved at several sites near prehistoric habitation sites. All waters found today in these coastal seeps are brackish (ca. 4-28 g of marine salt/L, compared to $1 \mathrm{~g} / \mathrm{L}$ or less for freshwater and $35 \mathrm{~g} / \mathrm{L}$ for seawater), which led Brosnan et al. (2018) to suggest that the Rapanui drank brackish water. As rain is the only freshwater source for recharging the groundwater system, such a supply should have been drastically reduced during the LIA drought, which suggests that the salinity of coastal seeps could have been higher than it is today. Therefore, it seems implausible that, as proposed by Brosnan et al. (2018), coastal seeps would have been the major freshwater sources circumventing the LIA freshwater crisis, which lasted for one century and a half, representing approximately six human generations. Lake Kao had plenty of freshwater during the LIA, and its shores were actively cultivated using local irrigation practices (Horrocks et al., 2012b). Therefore, it seems unreasonable that the Rapanui people refused to obtain freshwater from this lake, which is readily accessible from Orongo and other sites around the crater. Obtaining agricultural products but no freshwater from Lake Kao shores seems absurd in a period 
of water shortage such as the LIA drought (Rull, 2020b). A society that was able to transport almost 1000 megalithic sculptures such as the moai up to $18-20 \mathrm{~km}$ away from their quarry would not have been afraid to transport freshwater from Lake Kao shores to any part of the island. In the absence of island-wide irrigation structures, this transport could have been performed using bottle gourd (Lagenaria siceraria) fruits, which were intensively cultivated for such purpose across Polynesia in general (Clarke et al., 2006; Green, 2000) and on Easter Island in particular, including the Kao shores (Horrocks \& Wozniak, 2008; Horrocks et al., 2012a).

\section{Concluding remarks}

Two general lessons may be learned from the above results and discussion. One is that the prehistory of Easter Island is a complex subject that cannot be properly understood using simplifications to favor either one or another deterministic theory. Rather, natural and anthropogenic drivers of ecological and cultural changes, along with their potential feedbacks and synergies, should be considered to obtain a more objective explanation of the available evidence. The other lesson is the need for interdisciplinary studies conducted by researchers from a varied range of research fields. Each of these disciplines is part of the same puzzle, and we should learn to assemble them together instead of claiming the absolute truth using only our particular, always incomplete, set of pieces. 
Table 1. Characteristics of radiocarbon-dated peat and lake sediment cores obtained in Easter Island, according to the original references. The main proxies studied in each core are also indicated. ND = No data given in the original references.

Rano Aroi (270 05'37.37" N-109o 22' 26.50"; 433 m elevation)

\begin{tabular}{|l|l|l|l|l|l|l|}
\hline Core & $\begin{array}{l}\text { Water } \\
\text { Depth } \\
\text { (m) }\end{array}$ & $\begin{array}{l}\text { Core } \\
\text { Length } \\
\text { (m) }\end{array}$ & Year & $\begin{array}{l}\text { Coring } \\
\text { device }\end{array}$ & Main proxies studied & References \\
\hline ARO1 & 0.00 & $\sim 11.50$ & 1977 & Russian & $\begin{array}{l}\text { Lithostratigraphy, elemental } \\
\text { analysis, pollen and spores, } \\
\text { charcoal }\end{array}$ & $\begin{array}{l}\text { Flenley (1979), Flenley \& } \\
\text { King (1984), Flenley et al. } \\
\text { (1991) }\end{array}$ \\
\hline ARO 06-01 & 0.00 & 13.90 & 2006 & UWITEC & $\begin{array}{l}\text { Facies description, mineralogy, } \\
\text { elemental analysis, stable isotops, } \\
\text { plant and animal macrofossils, } \\
\text { pollen and spores }\end{array}$ & $\begin{array}{l}\text { Margalef (2014), Margalef } \\
\text { et al. (2013, 2014) }\end{array}$ \\
\hline ARO 08-02 & 0.00 & 4.00 & 2008 & Russian & $\begin{array}{l}\text { Facies description, mineralogy, } \\
\text { elemental analysis, stable isotops, } \\
\text { plant and animal macrofossils, } \\
\text { pollen and spores }\end{array}$ & $\begin{array}{l}\text { Margalef (2014), Margalef } \\
\text { et al. (2013, 2014), Rull et } \\
\text { al. (2015) }\end{array}$ \\
\hline RA2 & 0.00 & 8.00 & 1997 & Livingstone & $\begin{array}{l}\text { Lithostratigraphy, diffuse spectral } \\
\text { reflectance, pollen and spores }\end{array}$ & Peteet et al (2013) \\
\hline RA & 0.00 & 4.00 & 2009 & Russian & $\begin{array}{l}\text { Lithostratigraphy, magnetic } \\
\text { susceptibility, plant and animal } \\
\text { macrofossils, charcoal, pollen and } \\
\text { spores, biosilicates, phytoliths, } \\
\text { starch }\end{array}$ & Horrocks et al. (2015) \\
\hline RAI* & 0.00 & 2.11 & 2009 & Russian & $\begin{array}{l}\text { Lithostratigraphy, magnetic } \\
\text { susceptibility, plant and animal } \\
\text { macrofossils, charcoal, pollen and } \\
\text { spores, biosilicates, starch }\end{array}$ & Horrocks et al. (2015) \\
\hline
\end{tabular}

*Rano Aroi Iti (see Fig. 8)

Rano Kao (27ㅇ 11' 12.57' N-109 26'06.75"; 107 m elevation)

\begin{tabular}{|l|l|l|l|l|l|l|}
\hline Core & $\begin{array}{l}\text { Water } \\
\text { Depth } \\
\text { (m) }\end{array}$ & $\begin{array}{l}\text { Core } \\
\text { Length } \\
\text { (m) }\end{array}$ & Year & Coring device & Main proxies studied & References \\
\hline KAO1 & 0.00 & $\sim 11.00$ & 1977 & Russian & $\begin{array}{l}\text { Lithostratigraphy, elemental } \\
\text { analysis, pollen and spores, } \\
\text { charcoal }\end{array}$ & $\begin{array}{l}\text { Flenley (1979), Flenley } \\
\text { \& King (1984), Flenley et } \\
\text { al. (1991) }\end{array}$ \\
\hline 1 & ND & 20.00 & 2009 & $\begin{array}{l}\text { Russian } \\
\text { Livingstone }\end{array}$ & $\begin{array}{l}\text { Lithostratigraphy, magnetic } \\
\text { susceptibility, plant and animal } \\
\text { macrofossils, charcoal, pollen } \\
\text { and spores, starch }\end{array}$ & Horrocks et al. (2013) \\
\hline 2 & ND & $\sim 6.00$ & 2009 & $\begin{array}{l}\text { Russian } \\
\text { Livingstone }\end{array}$ & $\begin{array}{l}\text { Lithostratigraphy, phytoliths, } \\
\text { pollen and spores, starch }\end{array}$ & Horrocks et al (2012b) \\
\hline 3 & ND & $\sim 5.00$ & 2009 & $\begin{array}{l}\text { Russian } \\
\text { Livingstone }\end{array}$ & $\begin{array}{l}\text { Lithostratigraphy, phytoliths, } \\
\text { pollen and spores, starch }\end{array}$ & Horrocks et al (2012b) \\
\hline 4 & ND & $\sim 12.00$ & 2009 & $\begin{array}{l}\text { Russian } \\
\text { Livingstone }\end{array}$ & $\begin{array}{l}\text { Lithostratigraphy, phytoliths, } \\
\text { pollen and spores, starch }\end{array}$ & Horrocks et al (2012b) \\
\hline 5 & ND & $\sim 7.00$ & 2009 & $\begin{array}{l}\text { Russian } \\
\text { Livingstone }\end{array}$ & $\begin{array}{l}\text { Lithostratigraphy, phytoliths, } \\
\text { pollen and spores, starch }\end{array}$ & Horrocks et al (2012b) \\
\hline KAO2 & 10.50 & 20.85 & 1983 & $\begin{array}{l}\text { Russian } \\
\text { Lithostratigraphy, elemental } \\
\text { analysis, pollen and spores, } \\
\text { charcoal }\end{array}$ & $\begin{array}{l}\text { Butler \& Flenley (2001), } \\
\text { Butler \& Flenley (2010), } \\
\text { Butler et al. (2004), } \\
\text { Flenley (1996) }\end{array}$ \\
\hline KAO3 (KAO05- & 10.50 & 21.50 & 2005 & $\begin{array}{l}\text { Russian } \\
\text { Livingstone }\end{array}$ & $\begin{array}{l}\text { Magnetic susceptibility, oxygen } \\
\text { isotopes, pollen and spores }\end{array}$ & Gossen (2007, 2011) \\
\hline KAO08-03 & ND & 2.20 & 2008 & Russian & Lithostratigraphy, pollen and & Rull et al. (2018), \\
\hline
\end{tabular}


This paper is a non-peer reviewed EarthArXiv preprint

\begin{tabular}{|l|l|l|l|l|l|l|}
\hline & & & & $\begin{array}{l}\text { spores, charcoal, non-pollen } \\
\text { palynomorphs (NPP) }\end{array}$ & Seco et al. (2019) \\
\hline
\end{tabular}

Rano Raraku (270 07' 19.79" - 109 17' 20.66"; 80 m elevation)

\begin{tabular}{|c|c|c|c|c|c|c|}
\hline Core & $\begin{array}{l}\text { Water } \\
\text { Depth } \\
\text { (m) }\end{array}$ & $\begin{array}{l}\text { Core } \\
\text { Length } \\
\text { (m) }\end{array}$ & Year & $\begin{array}{l}\text { Coring } \\
\text { device }\end{array}$ & Main proxies studied & References \\
\hline RRA3 & 0.00 & $\sim 12.00$ & 1977 & Russian & $\begin{array}{l}\text { Lithostratigraphy, elemental } \\
\text { analysis, pollen and spores, } \\
\text { charcoal }\end{array}$ & $\begin{array}{l}\text { Flenley (1979), Flenley \& King } \\
\text { (1984), Flenley et al. (1991) }\end{array}$ \\
\hline RRA4 & 2.80 & $\sim 17.20$ & 1983 & Russian & $\begin{array}{l}\text { Lithostratigraphy, mineralogy, } \\
\text { elemental analysis }\end{array}$ & Flenley et al. (1991) \\
\hline RRA5 & ND & 13.40 & 2005 & Livingstone & Pollen and spores & Azizi \& Flenley (2008) \\
\hline SW & 2.00 & $\sim 3.40$ & 1990 & Piston & $\begin{array}{l}\text { Magnetic properties, plant and } \\
\text { animal microfossils (pollen, } \\
\text { cladocera, ostracoda, diatoms), } \\
\text { pigments }\end{array}$ & Dumont et al. (1998) \\
\hline 1 & 6.00 & $\sim 1.00$ & 1998 & Gravity & $\begin{array}{l}\text { Lithostratigraphy, magnetic } \\
\text { susceptibility, organic matter, } \\
\text { charcoal, pollen and spores }\end{array}$ & Mann et al. $(2003,2008)$ \\
\hline 2 & 6.00 & $\sim 1.00$ & 1998 & Gravity & Organic matter & Mann et al. $(2003,2008)$ \\
\hline RAR01 & ND & $\sim 5.70$ & 2006 & UWITEC & $\begin{array}{l}\text { Magnetic susceptibility, facies } \\
\text { description, elemental analysis, } \\
\text { mineralogy }\end{array}$ & Sáez et al. (2009) \\
\hline RAR02 & ND & $\sim 6.80$ & 2006 & UWITEC & $\begin{array}{l}\text { Magnetic susceptibility, facies } \\
\text { description, elemental analysis, } \\
\text { mineralogy }\end{array}$ & Sáez et al. (2009) \\
\hline RAR03 & ND & $\sim 13.80$ & 2006 & UWITEC & $\begin{array}{l}\text { Magnetic susceptibility, facies } \\
\text { description, elemental analysis, } \\
\text { mineralogy, plant and animal } \\
\text { macrofossils, pollen and spores }\end{array}$ & $\begin{array}{l}\text { Sáez et al. (2009), Cañellas- } \\
\text { Boltà (2014), Cañellas-Boltà et } \\
\text { al. }(2012,2014,2016)\end{array}$ \\
\hline RAR04 & ND & $\sim 6.00$ & 2006 & UWITEC & $\begin{array}{l}\text { Magnetic susceptibility, facies } \\
\text { description, elemental analysis, } \\
\text { mineralogy }\end{array}$ & Sáez et al. (2009) \\
\hline RAR05 & ND & $\sim 13.20$ & 2006 & UWITEC & $\begin{array}{l}\text { Magnetic susceptibility, facies } \\
\text { description, elemental analysis, } \\
\text { mineralogy }\end{array}$ & Sáez et al. (2009) \\
\hline RAR07 & ND & $\sim 12.80$ & 2006 & UWITEC & $\begin{array}{l}\text { Magnetic susceptibility, facies } \\
\text { description, elemental analysis, } \\
\text { mineralogy, plant and animal } \\
\text { macrofossils, pollen and spores }\end{array}$ & $\begin{array}{l}\text { Sáez et al. (2009), Cañellas- } \\
\text { Boltà (2014), Cañellas-Boltà } \\
\text { et al. (2012, 2014, 2016) }\end{array}$ \\
\hline RAR08 & ND & $\sim 12.60$ & 2006 & UWITEC & $\begin{array}{l}\text { Magnetic susceptibility, facies } \\
\text { description, elemental analysis, } \\
\text { mineralogy }\end{array}$ & $\begin{array}{l}\text { Sáez et al. (2009), Cañellas- } \\
\text { Boltà (2014), Cañellas-Boltà et } \\
\text { al. (2013) }\end{array}$ \\
\hline Lake & 2.60 & 2.25 & 2009 & Livingstone & $\begin{array}{l}\text { Lithostratigraphy, plant } \\
\text { macrofossils, pollen and spores, } \\
\text { phytoliths, starch }\end{array}$ & Horrocks et al. (2012a) \\
\hline
\end{tabular}

Table 2. Plants cultivated by the ancient Rapanui as recorded from pollen, phytoliths and starch in lake/swamp sediments ad in dryland soils.

\begin{tabular}{|l|l|l|l|l|}
\hline Taxa & Local name & Site & Proxy & Reference \\
\hline $\begin{array}{l}\text { Dioscorea } \\
\text { alata }\end{array}$ & Yam & $\begin{array}{l}\text { Dryland soils, } \\
\text { lake sediments } \\
\text { (Kao) }\end{array}$ & Starch & $\begin{array}{l}\text { Horrocks \& Wozniak (2008), } \\
\text { Horrocks et al. (2012b) }\end{array}$ \\
\hline $\begin{array}{l}\text { Lagenaria } \\
\text { siceraria }\end{array}$ & $\begin{array}{l}\text { Ipu kaha } \\
\text { (bottle gourd) }\end{array}$ & $\begin{array}{l}\text { Dryland soils, } \\
\text { lake sediments } \\
\text { (Kao, Raraku) }\end{array}$ & Pollen & $\begin{array}{l}\text { Horrocks \& Wozniak (2008), } \\
\text { Horrocks et al. (2012a) }\end{array}$ \\
\hline Ipomoea & Kumara & Dryland soils, & Pollen, & Horrocks \& Wozniak (2008), \\
\hline
\end{tabular}


This paper is a non-peer reviewed EarthArXiv preprint

\begin{tabular}{|l|l|l|l|l|}
\hline batatas & (sweet potato) & $\begin{array}{l}\text { lake sediments } \\
\text { (Kao, Raraku) }\end{array}$ & starch & Horrocks et al. (2012a, 2012b, 2016) \\
\hline $\begin{array}{l}\text { Colocasia } \\
\text { esculenta }\end{array}$ & Taro & $\begin{array}{l}\text { Dryland soils, } \\
\text { lake/swamp sediments } \\
\text { (Aroi, Kao, Raraku) }\end{array}$ & $\begin{array}{l}\text { Pollen, } \\
\text { starch }\end{array}$ & $\begin{array}{l}\text { Horrocks \& Wozniak (2008), } \\
\text { Horrocks et al. (2012a, 2012b, 2015, 2016) }\end{array}$ \\
\hline $\begin{array}{l}\text { Broussonetia } \\
\text { papyrifera }\end{array}$ & $\begin{array}{l}\text { Mahute } \\
\text { (paper mulberry) }\end{array}$ & $\begin{array}{l}\text { Dryland soils, } \\
\text { lake/swamp sediments } \\
\text { (Aroi, Kao) }\end{array}$ & Phytoliths & Horrocks et al. (2012b, 2016) \\
\hline Musa sp. & Maika (banana) & $\begin{array}{l}\text { Dryland soils, } \\
\text { lake/swamp sediments } \\
\text { (Aroi, Kao, Raraku) }\end{array}$ & Phytoliths & Horrocks et al. (2012a, 2012b, 2015, 2016) \\
\hline
\end{tabular}




\section{References}

Abram, N.J., Wright, N.M., Ellis, B., Dixon, B.C., Wurtzel, J.B., England, M.H., Ummenhofer, C.C., Philibosian, B., Cahyarini, S.Y., Yu, T.-L., Shen, C.-C., Cheng, H., Edwards, R.L., Heslop, D., 2020. Coupling of Indo-Pacific climate variability over the last millennium. Nature 579, 385-392.

Maloney, A.E., Nelson, D.B., Richey, J.N., Prebble, M., Sear, D.A., Hassall, J.D., Langdon, P.G., Croudace, I.W., Zawadzki, A., Sachs, J.P., 2019. Recosntructing precipitation in the tropical South Pacific from dinosterol ${ }^{2} \mathrm{H} /{ }^{1} \mathrm{H}$ ratios in lake sediment. Gecohim. Cosmochim. Acta 245, 190-206.

Ayres, W., 1975. Easter Island: Investigation in Prehistoric Cultural Dynamics. Report submitted to the National Science Foundation, University of South Carolina.

Azizi, G., Flenley, J.R., 2008. The last glacial maximum climatic conditions on Easter Island. Quat. Int. 184, $166-176$.

Bahn, P., 2015. The end of the moai - did they fall or were they pushed?, in: Cauwe, N., De Dapper, M. (Eds.), International Conference Easter Island: Collapse or transformation? A State of the Art. Royal Academy of Overseas Science, Royal Museums of Art and History, Belgian Science Policy Office, Brussels, pp. 135-152.

Bahn, P., Flenley, J., 1992. Easter Island, Earth Island. Tames \& Hudson, London.

Boersema, J.J., 2015. The Survival of Easter Island. Dwinling Resources and Cultural Resilience. Cambridge University Press, Cambridge.

Brandt, G., Merico, A., 2015. The slow demise of Easter Island: insights from a model investigation. Front. Ecol. Evol. 3, 13.

Brosnan, T., Becker, M.W., Lipo, C.P., 2018. Coastal groundwater discharge and the ancient inhabitants of Rapa Nui (Easter Island), Chile. Hydrogeol. J. 27, 519-534.

Bull, I.D., Lockheart, M.J., Elhmmali, M.M., Roberts, D.J., Evershed, R.P., 2002. The origin of faeces by means of biomarker detection. Environ. Int. 27, 647-654.

Butler, K., Prior, C.A., Flenley, J.R., 2004. Anomalous radiocarbon datesfrom Easter Island. Radiocarbon 46, 395-420.

Butler, K.R. \& Flenley, J.R., 2001. Further pollen evience from Easter Island. in: Stevenson, C.M., Lee, G., Morin, F.J. (Eds.), Pacific 2000. Proceedings of the Fifth International Conference on Easter Island and the Pacific, Easter Island Foundation, Los Osos, pp. 79-86.

Butler, K.R., Flenley, J.R., 2010. The Rano Kau 2 pollen diagram: palaeoecology revealed. Rapa Nui J. 24, 5-10.

Cañellas-Bolta, N., 2014. Vegetation Dynamics in Relation to Climate Changes, Geological Processes and Human Impact at Easter Island Since the Last Glacial. Paleoecological Study of Sediments from Lake Raraku. PhD Dissertation, University of Barcelona, Spain.

Cañellas-Boltà, N., Rull, V., Sáez, A., Margalef, O., Giralt, S., Pueyo, J.J., Birks, H.H., Birks, H.J.B., PlaRabes, S., 2012. Macrofossils in Raraku Lake (Easter Island) integrated with sedimentary and geochemical records: towards a palaeoecological synthesis of the last 34,000 years. Quat. Sci. Rev. 34, 113-126.

Cañellas-Boltà, N., Rull, V., Sáez, A., Margalef, O., Bao, R., Pla-Rabes, S., Blaauw, M., Valero-Garcés, B., Giralt, S., 2013. Vegetation changes and human settlement of Easter Island during the last millennia: a multiproxy study of the Lake Raraku sediments. Quat. Sci. Rev. 72, 36-48.

Cañellas-Boltà, N., Rull, V., Sáez, A., Prebble, M., Margalef, O., 2014. First records and potential paleoecological significance of Dianella (Xanthorrhoeaceae), an extinct representative of the native flora of Easter Island. Veget. Hist. Archaeobot. 23, 331-338.

Cañellas-Boltà, N., Rull, V., Sáez, A., Margalef, O., Bao, R., Pla-Rabes, S., Valero-Garcés, B., Giralt, S., 2016. Vegetation dynamics at Raraku Lake catchment (Easter Island) during the past 34,000 years. Palaeogeogr. Palaeoclimatol. Palaeoecol. 446, 55-69.

Carlquist, S., 1967. The biota of long-distance dispersal V. Plant dispersal to Pacific Islands. Bull. Torrey Bot. Club 44, 129-162.

Carlquist, S., 1974. Island Biology. Columbia Univ. Press, New York. 
Castañeda, I.S., Schouten, S., 2011. A review of molecular organic proxies for examining modern and ancient lacustrine environments. Quat. Sci. Rev. 30, 2851-2891.

Caviedes, C.N., Waylen, P.R., 2011. Rapa Nui: a climatically constrained island? Rapa Nui J. 25, 7-23.

CIREN, 2013. Mapa de Vegetación de Isla de Pascua. Centro de Información de Recursos Naturales, Ministerio de Agricultura, Santiago de Chile. Available at https://www.ciren.cl/; last view Nov. 6, 2019).

Ciszewski, A., Ryn, Z., Szelerewicz, M., 2009. The Caves of Easter Island: Underground World of Rapa Nui. Pracownia Kreatywna Bezliku, Kraków.

Commendador, A.S., Dudgeon, J.V., Finney, B.P., Fuller, B.T., Esh, K.S., 2013. A stable isotope (d13C and d15N) perspective on human diet on Rapa Nui. Am. J. Phys. Anthropol. 152, 173-185.

Commendador, A.S., Finney, B.P., Fuller, B.T., Tromp, M., Dudgeon, J.V., 2019. Multiproxy isotopic analyses of human skeletal material from Rapa Nui: evaluating the evidence from carbonates bulk collagen, and amino acids. Am. J. Phys. Anthropol. 169, 714-729.

Clarke, A.C., Burtenshaw, M.K., McLenachan, P.A., Erickson, D.L., Penny, D., 2006. Reconstructing the origins and dispersal of the Polynesian bottle gourd (Lagenaria siceraria). Mol. Biol. Evol. 23, 893900.

Cummings, L.S., 1998. A review of recent pollen and phytolith studies from vrious contexts on Easter Island, in: Stevenson, C.M., Lee, G., Morin, F.J. (Eds.), Easter Island in Pacific Context. Proceedings of the Fourth International Conference on Easter Island and East Polynesia. Easter Island Foundation, Los Osos, pp. 100-106.

D'Anjou, R.M., Bradley, R.S., Balascio, N.L., Finkelstein, D.B., 2012. Climate impacts on human settlement and agricultural activities in northern Norway revealed hrough sediment biogeochemistry. Proc. Natl. Acad. Sci. USA 109, 20332-20337.

De Boer, E.J., Rull, V., van Leeuwen, J.F.N., Amaral-Zettler, L.A., Bao, R., Benavente-Marín, M., Gonçalves, V., Hernández, A., Marques, H., Pimentel, C., Pla- Rabes, S., Raposeiro, P.M., Richter, N., Ritter, C., Rubio-Inglés, M.J., Sáez, A., Trigo, R.M., Vázquez-Loureiro, D., Vilaverde, J., Giralt, S., 2019. Ecosystem Impacts of human arrival in the Azores: a comparative study of high-resolution multi-proxy lake sediment records. $20^{\text {th }}$ Congres of the International Union of Quaternary Research (INQUA), Dublin, Ireland, O-3174.

Diamond, J., 2005. Collapse. How societies choose to fail or survive. Allen Lane, London.

Doswell, C.A., 2002. In the line of fire: first global lightning map reveals high-strike zones. Nat. Geogr. Mag. 202, vii.

Dransfield, J., Flenley, J.R., King, S.M., Harkness, D.D., Rapu, S., 1984. A recently extinct palm from Easter Island. Nature 312, 750-752.

Dumont, H.J., 2002. Impoverished freshwater fauna of Easter Island. Rapa Nui J. 16, 29-30.

Dumont, H.J., Cocquyt, C., Fortugne, M., Arnold, M., Reyss, J.L., Bloemendal, J., Oldfield, F., Steenbergen C.L.M., Korthals, H.J., Zeeb, B.A., 1998. The end of moai quarrying and its effect on Lake Rano Raraku, Easter Island. J. Paleolimnol. 20, 409-422.

Edwards, E., Edwards, A., 2013. When the Universe was an Island. Exploring the Cultural and Spiritual Cosmos of Ancient Rapanui. Hangaroa Press, Hanga Roa.

Eglington, T.I., Eglington, G., 2008. Molecular proxies for paleoclimatology. Earth Planet. Sci. Lett. 275, 116.

Englert, S., 1948. La Tierra de Hotu Matu'a: Historia y Etnología de la Isla de Pascua. San Franciso, Santiago.

Etienne, M., Michea, G., Díaz, E., 1982. Flora, vegetación y potencial pastoral de la Isla de Pascua. Fac. Ciencias Agrarias, Veterinarias y Forestales Univ. Chile, Santiago de Chile.

Fischer, S.R., 2005. Island at the End of the World. The Turbulent History of Easter Island. Reaktion Books, London.

Flenley, J.R., 1979. Stratigraphic evidence of environmental change on Easter Island. Asian Perspect. 22, 33-40. 
This paper is a non-peer reviewed EarthArXiv preprint

Flenley, J.R., 1996. Further evidence of vegetational change on Easter Island. South Pacific St. 16, 135141.

Flenley, J.R., 1998. New data and new thoughts about Rapa Nui, in: Stevenson, C.M., Lee, G., Morin, F.J. (Eds.), Easter Island in Pacific Context. Proceedings of the Fourth International Conference on Easter Island and East Polynesia. Easter Island Foundation, Los Osos, pp. 125-128.

Flenley, J.R., Bahn, P.G., 2003. The enigmas of Easter Island. Oxford Univ. Press, Oxford.

Flenley, J.R., Bahn, P.G., 2011. Hunt, Terry and Carl Lipo. The Statues tha Walked. Unravelling the mystery of Easter Island. Rapa Nui J. 25, 60-62.

Flenley, J.R., King, S., 1984. Late Quaternary pollen records from Easter Island. Nature 307, 47-50.

Flenley, J.R., King, A.S.M, Jackson, J., Chew, C., Teller, J.T., Prentice, M.E., 1991. The Late Quaternary vegetational and climatic history of Easter Island. J. Quat. Sci. 6, 85-115.

Follmann, G., 1961. Lichenometrische Alterbestimmungen an vorchristligen Steinsetzungen der polynesischen Osterinsel. Naturwissenschaften 19, 627-628.

Garreaud, R., Aceituno, P., 2001. Interannual rainfall variabilityover the South American Altiplano. J. Clim. 14, 2779-2789.

Genz, J., Hunt, T.L., 2003. El Niño/southern oscillations and Rapa Nui prehistory. Rapa Nui J. 17, 7-14.

Gioncada, A., González-Ferran, O., Lezzerini, M., Mazzuoli, R., Bisson, M., Rapu, S.A., 2010. The volcanic rocks of Easter Island (Chile) and their use for the moai sculptures. Eur. J. Mineral. 22, 855-867.

Glynn, P.W., Wellington, G.M., Wieters, E.A., Navarrete, S.A., 2003. Reef-building communities of Easter Island (Rapa Nui), Chile, in: Cortés, J. (Ed.), Latin American Coral Reefs. Elsevier, Amsterdam, pp. 473-494.

González-Ferrán, O., Mazzuoli, R., Lahsen, A., 2004. Geología del complejo volcánico Isla de Pascua, Rapa Nui, Chile, V Región Valparaiso. Carta Geológica-Volcánica Isla de Pascua. Centro de Estudios Volcanológicos, Santiago.

Gossen, C., 2007. Report: the mystery lies in the Scirpus. Rapa Nui J. 21, 105-110.

Gossen, C., 2011. Deforestation, Drought and Humans: New Discoveries of the Late Quaternary Paleoenvironment of Rapa Nui (Easter Island). PhD Dissertation, Portland State University, USA.

Green, R.C., 2000. A range of disciplines support a dual origin for the bottle gourd in the Pacific. J. Polynesian Soc. 109, 191-197.

Grolle, R., 2002. The hepaticae of Easter Island (Chile). Bryologist 105, 126-127.

Grove, R., Adamson, G., 2018. El Niño chronology and the Little Ice Age, in: Grove, R., Adamson, G. (Eds.), El Niño in World History. Palmgrave Macmillan, London, pp. 49-79.

Haberle, S.G., Chepstow-Lusty, A., 2000. Can climate influence cultural development? A view through time. Environ Hist 6, 349-369.

Haug, G., Günther, D., Peterson, L.C., Sigman, D.M., Hughen, K.A., Aeschlimann, B., 2003. Climate and the collapse of Maya civilization. Science 299, 1731-1735.

Herrera, C., Custodio, E., 2008. Conceptual hydrogeological model of volcanic Easter Island (Chile) after chemical and isotopic surveys. Hydrogeol. J. 16, 1329-1348.

Heyerdahl, T., 1952. American Indians in the Pacific: the Theory Behind the Kon-Tiki Expedition. Allen \& Unwin, London.

Heyerdahl, T., Ferdon, E., 1961. Reports of the Norwegian Archaeological Expedition to Easter Island and the East Pacific, Volume 1: Archaeology of Easter Island. Rand McNally, New York.

Hixon, S.W., Lipo, C.L., McMorran, B., Hunt, T.L., 2018. The colossal hats (pukao) of monumental statues on Rapa Nui (Easter Island, Chile): analyses of pukao variability, transport, and emplacememnt. J. Archaeol. Sci. 100, 148-157.

Hofreiter, M., Collins, M., Stwrat, J.R., 2012. Ancient biomolecules in Quaternary palaeoecology. Quaternary Science Reviews 33, 1-13.

Horrocks, M., Wozniak, J.A., 2008. Plant microfossil analysis reveals disturbed forest and a mixed-crop, dryland production system at Te Niu, Easter Island. J. Archaeol. Sci. 35, 126-142. 
Horrocks, M., Baisden, W.T., Flenley, J., Feek, D., González-Nualart, L., Haoa-Cardinali, S., Edmunds Gorman, T., 2012a. Fossil plant remains at Rano Raraku, Easter Island's statue quarry: evidence for past elevated lake level and ancient Polynesian agriculture. J. Paleolimnol. 46, 767-783.

Horrocks, M., Baisden, W.T., Nieuwoudt, M.K., Flenley, J., Feek, D., González Nualart, L., Haoa-Cardinali, S., Edmunds Gorman, T., 2012b. Microfossils of Polynesian cultigens in lake sediment cores from Rao Kau, Easter Island. J. Paleolimnol. 47, 185-204.

Horrocks,M., Marra,M., Baisden, W.T., Flenley, J., Feek, D., González-Nualart, L., Haoa-Cardinali, S., Edmunds Gorman, T., 2013. Pollen, phytoliths, arthropods and high-resolution ${ }^{14} \mathrm{C}$ sampling from Rano Kau, Easter Island: evidence for late quaternary environments, ant (formicidae) distributions and human activity. J. Paleolimnol. 50, 417-432.

Horrocks, M., Baisden,W. T., Harper, M. A., Marra, M., Flenley, J., Feek, D., Haoa-Cardinali, S., Keller, E.D., González Nualart, L., Edmunds Gorman, T., 2015. A plant microfossil record of Late Quaternary environments and human activity from Rano Aroi and surroundings, Easter Island. J. Paleolimnol. 54, 279-303.

Horrocks, M., Baisden, T., Flenley, J., Feek, D., Love, C., Haoa-Cardinali, S., González Nualart, L., Edmunds Gorman, T., 2016. Pollen, phytolith and starch analyses of dryland soils from Easter Island (Rapa Nui) show widespread vegetation clearance and Polynesian-introduced crops. Palynology 41, 339350.

Houlton, B.Z., Bai, E., 2009. Imprint of denitrifying bacteria on the global terrestrial biosphere. Proc. Natl. Acad. Sci. USA 106, 21713-21716.

Hunt, T.L., 2006. Rethinking the fall of Easter Island. New evidence points to and alternative explanation for a civilization's collapse. Am. Sci. 94, 412-419.

Hunt, T.L., 2007. Rethinking Easter Island's ecological catastrophe. J. Archaeol. Sci. 34, 485-502.

Hunt, T.L., Lipo, C.P., 2006. Late colonization of Easter Island. Science 311, 1603-1606.

Hunt, T.L., Lipo, C., 2011. The Statues that Walked. Free Press, NewYork.

Hunt, T.L., Lipo, C.P., 2018 The archaeology of Rapa Nui (Easter Island), in: Cochrane, E.E., Hunt, T.L. (Eds.), The Oxford handbook of Prehistori Oceania. Oxford University Press, Oxford, pp. 416-449.

Hunter-Anderson, R.L., 1998. Human vs. climatic impacts at Rapa Nui, Did people really cut down all those trees?, in: Stevenson, C.M., Lee, G., Morin, F.J. (Eds.), Easter Island in Pacific Context. Proceedings of the Fourth International Conference on Easter Island and East Polynesia. Easter Island Foundation, Los Osos, pp. 95-99.

Ireland, R.R., Bellolio, G., 2002. The mosses of Easter Island. Trop. Briol. 21, 11-19.

Jarman, C.L., Larsen, T., Hunt, T.L., Lipo, C.P., Solsvik, R., Wallsgrove, N., Ka'apu-Lyons, C., Close, H.G., Popp, B.N., 2017. Diet of the prehistoric population of Rapa Nui (Easter Island, Chile) shows environmental adaptation and resilience. Am. J. Phys. Anthropol. 164, 343-361.

Jones, T.L., Storey, A.A., Matisoo-Smith, E., Ramírez-Aliaga, J.M., 2011. Polynesians in America. PreColumbian Contact with the New World. Altamira Press, Landham.

Kirch, P.V., 1984. The Evolution of the Polynesian Chiefdoms. Cambridge University Press, Cambridge. Kirch, P.V., 2010. Peopling of the Pacific: a holistic anthropological perspective. Annu. Rev. Anthropol. 39, 131-148.

La Pérouse, J.F.G., 1797. Voyage de La Pérouse Autour du Monde. Imprimerie de la République, Paris. Lee, G., 1992. The Rock Art of Easter Island. Symbols of Power, Prayers to the goods. Institute of Archaeology, University of California, Los Angeles.

Lipo, C.P., Hunt, T.L., 2005. Mapping prehistoric statue roads on Easter Island. Antiquity 79, 158-168.

Lipo, C.P., Hunt, T.L., 2016. Chronology and Easter Island prehistory, in: Stefan, V.H., Gill, G.W. (Eds.), Skeletal Biology of the Ancient Rapanui (Easter Islanders). Cambridge University Press, Cambridge, pp. 39-65.

Lipo, C.P., Hunt, T.L., Rapu, S., 2013. The 'walking' megalithic statues (moai) of Easter Island. J. Archaeol. Sci. 40, 2859-2866.

MacIntyre, F., 2001. ENSO, climate variability and the Rapanui. Part II, oceanography and the Rapanui. Rapa Nui J. 15, 83-94. 
Mann, D, Chase, J., Edwards, J., Beck, W., Reanier, R., Mass, M., 2003. Prehistoric destruction of the primeval soils and vegetation of Rapa Nui (Isla de Pascua, Easter Island), in: Loret, J., Tanacredi, J.T. (Eds.), Easter Island. Scientific Exploration into the World's Environmental Problems in Microcosm. Kluwer Academic/Plenum, New York, pp. 133-153.

Mann, D., Edwards, J., Chase, J., Beck, W., Reanier, R., Mass, M., Finney, B., Loret, J., 2008. Drought, vegetation change, and human history on Rapa Nui (Isla de Pascua, Easter Island). Quat. Res. 69, $16-28$.

Margalef, O., 2014. The Last 70 kyr of Rano Aroi (Easter Island, $27^{\circ} \mathrm{S}$ ) Peat Record: New Insights for the Central Pacific Paleoclimatology. PhD Dissertation, University of Barcelona, Spain.

Margalef, O., Cañellas-Boltà, N., Pla-Rabes, S., Giralt, S., Pueyo, J.J., Joosten, H., Rull, V., Buchaca, T., Hernández, A., Valero-Garcés, B.L., Moreno, A., Sáez, A., 2013. A 70,000 year geochemical and palaeoecological record of climatic and environmental change from Rano Aroi peatland (Easter Island). Glob. Planet. Change 108, 72-84.

Margalef, O., Martínez-Cortizas, A., Kylander, M., Pla-Rabes, S., Cañellas-Boltà, N., Pueyo, J.J., Sàez, A., Valero-Garcés, B., Giralt, S., 2014. Environmental processes in Rano Aroi (Easter Island) peat geochemistry forced by climate variability during the last 70 kyr. Palaeogeogr. Palaeoclimatol. Palaeoecol. 414, 438-450.

Margalef, O., Álvarez-Gómez, J.S., Pla-Rabes, S., Cañellas-Boltà, N., Rull, V., Sáez, A., Geyer, A., Peñuelas, J., Sardans, J., Giralt, S., 2018. Revisiting the role of high-enegry Pacific events in the environmental and cultural history of Easter Island (Rapa Nui). Geogr. J. 184, 310-322.

Martinsson-Wallin, H., 2001. Construction - destruction - reconstruction of monumental architerchture on Rapa Nui, in: Stevenson, C.M., Lee, G., Morin, F.J. (Eds.), Pacific 2000. Proceedings of the Fifth International Conference on Easter Island and the Pacific, Easter Island Foundation, Los Osos, pp. 73-77.

Martinsson-Wallin, H., Crockford, S.J., 2002. Early settlement of Rapa Nui (Easter Island). Asian Perspect. 40, 244-278.

Maunder, M., Culham, A., Alden, B., Zizka, G., Orliac, C., Lobin,W., Bordeu, A., Ramírez, J.M., GlissmannGough, S., 2000. Conservation of the Toromiro tree, case study in the management of a plant extinct in the wild. Conserv. Biol. 14, 1341-1350.

McCall, G., 1981. Rapanui. Tradition and Survival on Easter Island. Univ. Press Hawaii, Honolulu.

McCall, G. 1993. Little Ice Age, some speculations for Rapanui. Rapa Nui J. 7, 65-70.

McCall, G., 2009. Easter Island, in: Gillespie, R.G., Clague, D.A. (Eds.), Encyclopedia of Islands, University of California Press, Berkeley, pp. 244-251.

McLauchlan, K.K., Williams, J.J., Craine, J.M., Jeffers, E.S., 2013. Changes in nitrogen cycling during the Holocene epoch. Nature 495, 352-355.

McLaughlin, S., 2007. The Complete Guide to Easter Island. Easter Island Foundation, Los Osos.

Métraux, A., 1940. Ethnology of Easter Island. Bishop Museum, Honolulu.

Meyer, J.Y., 2013. A note on the taxonomy, ecology, distribution and conservation status of the ferns (Pteridophytes) of Rapa Nui (Easter Island). Rapa Nui J. 27, 71-83.

Mieth, A., Bork, H.R., 2003. Diminution and degradation of environmental resources by prehistoric land use on Poike peninsula, Easter Island (Rapa Nui). Rapa Nui J. 17, 34-41.

Mieth, A., Bork, H.R., 2005. History, origin and extent of soil erosion on Easter Island (Rapa Nui). Catena 63, 244-260.

Mieth, A., Bork, H.R., 2010. Humans, climate or introduced rats -which is to blame for the woodland destruction on prehistoric Rapa Nui (Easter Island)? J. Archaeol. Sci. 37, 417-426.

Mieth, A., Bork, H.R., 2015. Degradation of resources and successful land-use management on prehistoric Rapa Nui: two sides of the same coin, in: Cauwe, N., De Dapper, M. (Eds.), International Conference Easter Island: Collapse or transformation? A State of the Art. Royal Academy of Overseas Science, Royal Museums of Art and History, Belgian Science Policy Office, Brussels, pp. 91-113. 
This paper is a non-peer reviewed EarthArXiv preprint

Mieth, A., Bork, H.R., 2017. A vanished landscape - phenomena and eco-cultural consequences of extensive deforestation in the prehistory of Rapa Nui, in: Haoa Cardinali, S., Ingersoll, K.B., Stevenson, C.M. (Eds.), Cultural and Environmental Change on Rapa Nui. Routledge, London, pp. 32-58.

Mieth, A., Bork, H.R., Feeser, I., 2002. Prehistoric and recent land use effects on Poike peninsula, Easter Island (Rapa Nui). Rapa Nui J. 16, 89-95.

Mucciarone, D.A., Dunbar, R.B., 2003. Stable iotope record of El Niño-Southern Oscillation events from Easter Island, in: Loret, J., Tanacredi, J.T. (Eds.), Easter Island. Scientific Exploration into the World's Environmental Problems in Microcosm. Kluwer Academic/Plenum, New York, pp. 113-132.

Mulloy, W., 1970. A speculative reconstruction of techniques of carving, transporting and erecting Easter Island statues. Archaeol. Phys. Anthropol. Oceania 5, 1-23.

Mulloy, W., 1974. Contemplate the Navel of the World. Américas 26, 25-33.

Mulloy, W., 1979. A preliminary culture-historical research model for Easter Island. In: Echevarría, G., Arana, P. (Eds.), Las Islas Oceánicas de Chile. Univ. Chile, Santiago de Chile, pp. 105-151.

Mulloy, W., 1997. Preliminary culture-historical research model for Easter Island. In: The Easter Island Bulletins of William Mulloy. World Monumets Fund \& Easter Island Foundation, New York \& Houston, pp. 97-111.

Mulrooney, M.A., 2013. An island-wide assessment of the chronology of settlement and land use on Rapa Nui (Easter Island) based on radiocarbon data. J. Archaeol. Sci. 40, 4377-4399.

Mulrooney, M., 2013. An island-wide assessment of the chronology of settlement and land use on RapaNui (Easter Island) based on radiocarbon data. J. Archaeol. Sci. 40, 4377-4399.

Negri, A,J., Adler, R.F., Shepherd, J.M., Huffman G., Manyin, M., Neklin, E.J., 2004. A 16-year climatology of global rainfall from SSM/I highlighting morning versus evening effects. $13^{\text {th }}$ American Meteorological Conference on Satellite Meteorology and Oceanography, Norfolk, P6.16.

Nunn, P.D., 2000. Environmental catastrophe in the Pacific Islands around A.D. 1300. Geoarchaeol. 15, 715-740.

Nunn, P.D., 2007. Climate, Environment and Society in the Pacific During the Last Millennium. Elsevier, Amsterdam.

Nunn, P.D., Britton, J.M.R., 2001. Human-environment relationships in the Pacific, Islands around A.D. 1300. Environ. Hist. 7, 3-22.

O'Leary, M.H., 1988. Carbon isotopes in photosynthesis. BioScience 38, 328-336.

Orliac, C., 2000. The woody vegetation of Easter Island between the early $14^{\text {th }}$ and the mid-1 $17^{\text {th }}$ centuries AD, in: Stevenson, C.M., Ayres, W.S. (Eds.), Easter Island Archaeology. Research on Early Rapanui Culture, Easter Island Foundation, Los Osos, pp. 211-220.

Orliac, C., Orliac, M., 1998. The disappearance of Easter Island's forest: over-exploitation or climatic catastrophe?, in: Stevenson, C.M., Lee, G., Morin, F.J. (Eds.), Easter Island in Pacific Context. Proceedings of the Fourth International Conference on Easter Island and East Polynesia. Easter Island Foundation, Los Osos, pp. 129-134.

Parducci, L., Bennett, K.D., Ficetota, G.F., Alsos, I.G., Suyama, Y., Wood, J.R., Pedersen, M.W., 2017. The ancient plant DNA in lake sediments. New Phytol. 214, 924-942.

Peiser, B., 2005. From genocide to ecocide, the rape of Rapa Nui. Energy Environ. 16, 513-539.

Peteet, D., Beck, W., Ortiz, J., O'Connell, S., Kurdyla, D., Mann, D., 2003. Rapid vegetational and sediment change from Rano Aroi crater, Easter Island, in: Loret, J., Tanacredi, J.T. (Eds.), Easter Island. Scientific Exploration into the World's Environmental Problems in Microcosm. Kluwer Academic/Plenum, New York, pp. 81-92.

Pinart, A., 1878. Exploration de l'île de Pâques. Bull. Soc. Géogr. 16, 193-213.

Polet, C., 2015. Starvation and cannibalsim on Easter Island? The contribution of the analysis of Rapanui human remains, in: Cauwe, N., De Dapper, M. (Eds.), International Conference Easter Island: Collapse or transformation? A State of the Art. Royal Academy of Overseas Science, Royal Museums of Art and History, Belgian Science Policy Office, Brussels, pp. 115-133. 
Polet, C., Bocherens, H., 2016. New insights into the marine contribution to ancient Easter Islander's diet. J. Archaeol. Sci. Rep. 6, 709-719.

Puleston, C.O., Ladefoged, T.N., Haoa, S., Chadwick, O.A., Vitousek, P.M., Stevenson, C.M., 2017. Rain, sun, soil, and sweat: a consideration of population limits on Rapa Nui (Easter Island) beofre European contact. Front. Ecol. Evol. 5, 69.

Rainbird, P., 2002. A message for our future? The Rapa Nui (Easter Island) ecodisaster and Pacific environments. World Achaeol. 33, 436-451.

Rawlence, N.J., Lowe, D.J., Wood, J.R., Young, J.M., Churchman, G.J., Huang, Y.T., Cooper, A., 2014. Using palaeoenvironmental DNA to reconstruct past environments: progresses and prospects. J. Quat. Sci. 29, 610-626.

Robinson, T., Stevenson, C. M., 2017. The cult of the Birdman: religious change at 'Orongo, Rapa Nui (Easter Island). J. Pacif. Archaeol. 8, 88-102.

Rorrer, K., 1998. Subsistence evidence from inland and coastal cave siteson Easter Island, in: Stevenson, C.M., Lee, G., Morin, F.J. (Eds.), Easter Island in Pacific Context. Proceedings of the Fourth International Conference on Easter Island and East Polynesia. Easter Island Foundation, Los Osos, pp. 193-198.

Routledge, K., 1919. The Mystery of Easter Island. The Story of an Expedition. Shifton, Praed \& Co., London.

Rull, V., 2016a. Natural and anthropogenic drivers of cultural change at Easter Island: review and new insights. Quat. Sci. Rev. 150, 31-41.

Rull, V., 2016b. The EIRA database: Last Glacial and Holocene radiocarbon ages from Easter Island's sedimentary records. Front Ecol. Evol. 4, 44.

Rull, V. 2018. Strong Fuzzy EHLFS: a general conceptual framework to address past records of environmental, ecological and cultural change. Quaternary 1, 10.

Rull, V., 2019. Human discovery and settlement of the remote Easter Island (SE Pacific). Quaternary 2, 15.

Rull, V., 2020a. The deforestation of Easter Island. Biol. Rev. 95, 121-141.

Rull, V. 2020b. Drought, freshwater availability and cultural resilience on Easter Islad (SE Pacific) during the Little Ice Age. Holocene, doi 10.1177/0959683619895587.

Rull, V., Cañellas-Boltà, N., Sáez, A., Margalef, O., Bao, R., Pla-Rabes, S., Valero-Garcés, B., Giralt, S., 2013. Challenging Easter Island's collapse: The need for interdisciplinary synergies. Front. Ecol. Evol. $1,3$.

Rull, V., Cañellas-Boltà, N., Margalef, O., Sáez, A., Pla-Rabes, S., Giralt, S., 2015. Late Holocene vegetation dynamics and deforestation in Rano Aroi: Implications for Easter Island's ecological and cultural history. Quat. Sci. Rev. 126, 219-226.

Rull, V., Cañellas-Boltà, N., Margalef, O., Pla-Rabes, S., Sáez, A. \& Giralt, S., 2016. Three millennia of climatic, ecological and cultural change on Easter Island: a synthetic overview. Front. Ecol. Evol. 4, 29.

Rull, V., Lara, A., Rubio-Inglés, M.J., Giralt, S., Gonçalves, V., Raposeiro, P., Hernández, A., Sánchez-López, G., Vázquez-Loureiro, D, Bao, R., Masqué, P., Sáez, A., 2017. Vegetation and landscape dynamics under natural and anthropogenic forcing on the Azores Islands: A 700-year pollen record from the São Miguel Island. Quat. Sci. Rev. 159, 155-168.

Rull, V., Montoya, E., Seco, I., Cañellas-Boltà, N., Giralt, S., Margalef, O., Pla-Rabes, S., D’Andrea, W., Bradley, R., Sáez, A., 2018. CLAFS, a holistic climatic-ecological anthropogenic hypothesis on Easter Island's deforestation and cultural change: proposals and testing prospects. Front. Ecol. Evol. 6, 32.

Sáez, A., Valero-Garcés, B., Giralt, S., Moreno, A., Bao, R., Pueyo, J.J., Hernández, A., Casas, D., 2009. Glacial to Holocene climate changes in the SE Pacific. The Raraku Lake sedimentary record (Easter Island, $27^{\circ}$ S). Quat. Sci. Rev. 28, 2743-2759.

Sear, D.A., Allen, M.S., Hassall, J.D., Maloney, A.E., Langdon, P.G., Morrison, A.E., Henderson, A.C.G., Mackay, H., Croudace, I.W., Clarke, C., Sachs, J.P., Macdonald, G., Chiverrell, R.C., Leng, M.J., 
Cisneros-Dozal, L.M., Fonville, T., 2020. Human settlement of East Polynesia earlier, incremental, and coincident with prolonged South Pacific drought. Proc. Natl. Acad. Sic. USA 117, 8813-8819.

Seco, I., Rull, V., Montoya, E., Cañellas-Boltà, N., Giralt, S., Margalef, O., Pla-Rabes, S., D’Andrea, W.J., Bradley, R.S., Sáez, A. 2019. A continuous palynological record of forest clearing at Rano Kao (Easter Island, SE Pacific) during the last millennium: preliminary report. Quaternary 2, 22.

Sherwood, S.C., Van Tilburg, J.A., Barrier,C.R., Horrocks, M., Dunn, R.K., Ramírez-Aliaga, J.M., 2019. New excavations in Easter island's statue quarry: soil fertility, site formation and chronology. J. Archaeol. Sci. 111, 104994.

Skottsberg, C., 1920-1956. The Natural History of Juan Fernandez and Easter Island (6 vols.). Almqvist \& Wiksells, Uppsala.

Smith, C.S., 1961. A temporal sequence derived from certain ahu, in: Heyerdahl, T., Ferdon, E. (Eds.), Reports of the Norwegian Archaeological Expedition to Easter Island and the East Pacific, Volume 1: Archaeology of Easter Island. Allen \& Unwin, London, pp. 181-218.

Steadman, D.W., Vargas, P., Cristino, C., 1994. Stratigraphy, chronology, and cultural context of an early faunal assemblage from Easter Island. Asian Perspect. 33, 79-96.

Stenseth, N.C., Voje, K.L., 2009. Easter Island: climate change might have contributed to past cultural and societal changes. Clim. Res. 39, 111-114.

Stevenson, C.M., 1986. The sociopolitical structure of the southern coastal area of Easter Island: AD 1300-1864, in: Kirch, P.V. (Ed.), Island Societies: Archaeological Approaches to Evolution and Transformation. Cambridge University Press, Cambridge, pp. 69-77.

Stevenson, C.M., Wozniak, J., Haoa, S., 1999. Prehistoric agricultural production on Easter Island (Raoa Nui), Chile. Antiquity 73, 801-812.

Stevenson, C.M., Ramírez, J.M., Haoa, S., Allen, T., 2000. Archaeological investigations at 'Anakena beach and other near-coastal locations, in: Stevenson, C.P., Ayres, W.S. (Eds.), Easter Island Archaeology: Research on Early Rapanui Culture. Easter Island Foundation, Los Osos, pp. 147-172.

Stevenson, C.M., Puleston, C.O., Vitousek, P.M., Chadwick, O.A., Haoa, S., Ladefoged, T.N., 2015. Variation in Rapa Nui (Easter Island) land use indicates producyion and population peaks prior to European contact. Proc. Natl. Acad. Sci. USA 112, 1025-1030.

Thorsby, E., 2007. Evidence of an early Amerindian contribution to the Polynesian gene pool on Easter Island, in: Wallin, P., Martrinsson-Wallin, H. (Eds.), The Gotland Papers. Selected Papers from the VII International Conference on Easter Island and the Pacific. Migration, Identity, and Cultural Heritage. Gotland University Press, Sweden, pp. 285-295.

Thorsby, E., 2016. Genetic evidence of a contribution of Native Americans to the early settlement of Rapa Nui (Easter Island). Front. Ecol. Evol. 4, 118.

Trenberth, K.E., 2019. El Niño Sothern Oscillation (ENSO). Encyclopedia of Ocean Sciences 6, 420-432.

Van Balgooy, M.M.J., 1960. Preliminary plant geographical analysis of the Pacific as based on the distribution of phanerogam genera. Blumea 10, 385-430.

Van Geel, B., Buurman, J., Brinkkemper, O., Schelvis, J., Aptroot, A., van Reenen, G., Hakbijl, T., 2003. Environmetal reconstruction of a Roman Period settlement site in Uitgeest (The Netherlands), with special reference to coprophilous fungi. J. Archaeol. Sci. 30, 873-883.

Van Tilburg, J. A., 1994. Easter Island: Archaeology, Ecology, and Culture. Smithsonian Inst. Press, Washington.

Vargas, P., Cristino, C., Izaurieta, R., 2006. 1.000 años en Rapa Nui. Cronología del asentamiento. Editorial Universitaria, Santiago de Chile.

Vezzoli, L., Acocella, V., 2009. Easter Island, SE Pacific: and end-member type of hotspot volcanism. Geol. Soc. Am. Bull. 121, 869-886.

Wallin, P., Martisson-Wallin, H., Possnert, G., 2010. Re-dating Ahu Nau Nau and the settlement at 'Anakena, Rapa Nui, in: Wallin, P., Martinsson-Wallin, H. (Eds.), The Gotland Papers. Selected Papers from the VII International Conference on Easter Island and the Pacific, Gotland University, Sweden, pp. 37-46. 
Wilmshurst, J.M., Hunt, T.L., Lipo, C.P., Anderson, A.J., 2011. High-precision radiocarbon dating shows recent and rapid initial human colonization of East Polynesia. Proc. Natl. Acad. Sci. USA 108, 18151820.

Wozniak, J.A., 1999. Prehistoric horticultural practices on Easter Island: lithic mulched gardens and field streams. Rapa Nui J. 13, 95-99.

Wozniak, J.A., 2001. Landscapes of food production on Easter Island: successful subsistence strategies, in: Stevenson, C.M., Lee, G., Morin, F.J. (Eds.), Pacific 2000. Proceedings of the Fifth International Conference on Easter Island and the Pacific, Easter Island Foundation, Los Osos, pp. 91-101.

Wozniak, J.A., 2017. Subsistence strategies on Rapa Nui (Easter Island). Prehistoric gardening practices on Rapa Nui and how they related to current farming practices, in: Haoa Cardinali, S., Ingersoll, K.B., Stevenson, C.M. (Eds.), Cultural and Environmental Change on Rapa Nui. Routledge, London, pp. 87-112.

Wozniak, J.A., Horrocks, M., Cummings, L., 2007. Plant microfossil analysis of deopists from Te Niu, Rapa Nui, demonstrates forest disruption C. AD 1300 and subsequent dryland multi-cropping, in: Wallin, P., Martrinsson-Wallin, H. (Eds.), The Gotland Papers. Selected Papers from the VII International Conference on Easter Island and the Pacific. Migration, Identity, and Cultural Heritage. Gotland University Press, Sweden, pp. 111-124.

Zizka, G., 1991. Flowering Plants of Easter Island. Palmarum Hortus Francofurtensis, Frankfurt Main. 
This paper is a non-peer reviewed EarthArXiv preprint

\section{Figure captions}

Figure 1. Sketch map of the Pacific archipelagos. Easter Island is highlighted by a red dot and the distances (in km) to the nearest Polynesian and American islands, according to Flenley \& Bahn (2003), are indicated.

Figure 2. Topographic sketch-map of Easter Island. Dotted lines represent elevations at 100-m intervals. Blue circles indicate the permanent freshwater bodies (Rano Aroi, Rano Kao and Rano Raraku). The approximate extension of the capital (Hanga Roa) is represented in gray. Red dots indicate the approximate distribution of present-day moai and ahu, combining maps from Van Tilburg (1994) and Lipo et al. (2013). Unfinished moai at Rano Raraku quarry cannot be represented at this scale. Green lines are part of the road network used by the ancient Rapanui for moai transportation, as reconstructed by Lipo \& Hunt (2005).

Figure 3. Main climatic systems of the South Pacific (ITCZ - Intertropical Convergence Zone, SPCZ South Pacific Convergence Zone, SPA - South Pacific Anticyclone, ST - Storm Tracks). Colours indicate precipitation gradients from $<100$ (black) to $>1200$ (red) mm per year, for the period 1987-2003. Easter Island is represented by a red dot. Composed and modified from Negri et al. (2004).

Figure 4. Panoramic views of the three permanent freshwater sources of Easter Island, containing sediments suitable for paleoecological research. Photos: V. Rull.

Figure 5. Schematic cross-section of a N-S transect showing the hydrological model of Easter Island. Note the progressive thinning of the freshwater table toward the coast. The approximate elevation of lakes Kao and Raraku and the position of the Aroi swamp are indicated. Redrawn and simplified from Herrera \& Custodio (2008).

Figure 6. Vegetation map of Easter Island, indicating the approximate total extension of each vegetation type. The category "others" includes urban areas, cliffs, crater walls and waterbodies, among others. Redrawn and modified from CIREN (2013).

Figure 7. Examples of moai from different parts of Easter Island (see Fig. 2 for location) and size comparison at human scale. A) Ahu Nau Nau, B) Ahu Ko Te Riku C) Ahu Tongariki, D) Ahu Vai Uri (left) and Ahu Tahai (right), E) Moai from Ahu Tongariki, F) Moai from Ahu Te Pito Kura. Photos: N. Cañellas (A and C) and V. Rull (B and D).

Figure 8. Google-Earth images of the paleoecological sites of Easter Island indicating all cores retrieved to date with published results, which constitute the basis for the EIRA radiocarbon database discussed in the text. MQ - Moai Quarry, slopes where most moai were carved. Modified from Rull (2016b).

Figure 9. Selection of the most representative chronological frameworks for the prehistory of Easter Island, sorted by publication dates (bottom to top). The three phases/periods with similar, but not identical, cultural patterns have been highlighted with different colors, except the latest published "chronology", which is in gray. Note the strong disagreement among the different dates for island settlement and for the boundaries among the different phases/periods defined. Fg - Moai fragmentation, HM - Huri Moai, LP - Late Period, WF - Warfare.

Figure 10. Peopling of the Pacific from East Asian archipelagos. $\mathrm{H}$ - Henderson Island; $\mathrm{M}$ - Mangareva Island, P - Pitcairn Island. Raw data from Kirch (2010). The approximate trajectory of Heyerdahl's KonTiki expedition (1947 CE) is also indicated (green arrow). 
Figure 11. Simplified percentage pollen diagrams of cores RRA3 (Rano Raraku) and KAO1 (Rano Kao) (Fig. 8, Table 1) with the most important taxa used by Flenley et al. (1991) to record the palm-forest demise and its replacement by grass meadows.

Figure 12. Simplified percentage pollen diagram of core ARO1 (Fig. 8, Table 1) with the most important taxa used by Flenley et al. (1991) to reconstruct the Late Pleistocene and Holocene vegetation dynamics in the Aroi catchment. D - Disturbed.

Figure 13. Landscape and demographic inferences for Easter Island based on the Rano Kao pollen record, which suggested a series of events starting with forest overexploitation and ending in sudden population decline. Redrawn from Bahn \& Flenley (1992).

Figure 14. Soil profile from Poike showing the upward succession of a primeval soil with weathered volcanic rocks and garden soils with palm root casts. Forest clearing left some charcoal accumulations on the top of the primeval soil that was truncated by erosion and covered by a sheet of fine-layered sediments. Redrawn and modified from Mieth \& Bork (2010).

Figure 15. Calibrated radiocarbon ages of charcoal from soils overlying the primeval forest soils (blue bars) and main prehistorical events (orange bars and red arrows). E - European contact. Redrawn and simplified from Mann et al. (2003).

Figure 16. Simplified percentage pollen diagram of core \#1 from Rano Raraku. The depositional hiatus is indicated by a gray band. Redrawn and simplified from Mann et al. (2008).

Figure 17. N-S transect showing the sedimentary units and the internal architecture of Lake Raraku sediments. The cores used to reconstruct the units are shown in blue lines (see Fig. 8 for location). Unit ages are given in cal kyr (yr in Unit 4) BP. Simplified from Sáez et al. (2009).

Figure 18. Summary pollen diagram of Rano Kao core KAO2 after Butler \& Flenley (2010). Radiocarbon ages from Scirpus fruits are in black and those from bulk sediment in blue.

Figure 19. Percentage pollen diagrams of Late Holocene sequences from Rano Kao, Rano Aroi and Rano Raraku cores, simplified from the references given (Horrocks et al., 2012a, 2013, 2015). The dotted line in the Rano Aroi core separates the pre-contact (below) and the post-contact (above) parts of the sequence.

Figure 20. Age-depth models of the continuous and chronologically coherent sedimentary records of the last millennia recovered in Rano Raraku, Rano Aroi and Rano Kao. Dotted lines in the Raraku model around $10 \mathrm{~cm}$ and $20 \mathrm{~cm}$ indicate minor sedimentary gaps. Redrawn and modified from Rull (2020a).

Figure 21. Summary diagram of the last ca. 3700 years as represented in core RAR08 from Rano Raraku. Sedimentary gaps are represented as gray bands with indication of the years lacking in each case. Black arrows indicate remarkable events discussed in the text. N.D. - No Data. Redrawn and modified from Cañellas-Boltà et al. (2013).

Figure 22. Verbena litoralis pollen. $A$ to $D$, pollen from the species presently growing within the Raraku crater, near the coring site, collected in the field by N. Cañellas-Boltà. E to $\mathrm{H}$, pollen from sediments of core RAR08. Vertical bars represents $10 \mu \mathrm{m}$. Modified from Cañellas-Boltà et al. (2013). 
Figure 23. Summary diagram of core ARO08-03 (Rano Aroi) showing the main palynomorphs and the main geochemical parameters used as paleoclimatic proxies. Gray bands indicate drier climates linked to processes of landscape opening (LO1, LO2, LO3). Modified from Rull et al. (2015).

Figure 24. Summary pollen diagram of Rano Kao core KAO08-03 after Seco et al. (2019). Deforestation pulses are marked by red triangles and forest regeneration trends are indicated by blue arrows.

Figure 25. Reconstructed climatic trends of the last two millennia based on sedimentology, physicochemical proxies and biological proxies other than pollen and spores in Rano Raraku and Rano Aroi (cores RAR08 and ARO08-02, respectively). Raw data from Cañellas-Boltà et al. (2013) and Rull et al. (2015). Droughts are highlighted by a gray band. Blue arrows are regional volcanic eruptions occurred during Easter Island's prehistory (K- Kauwe eruption, S - Samalas eruption) (Margalef et al., 2018). DACP - Dark Ages Cold Period, LIA - Little Ice Age, MCA - Medieval Climate Anomaly, RWP - Roman Warm Period.

Figure 26. Synthetic diagrams of Rano Raraku (Cañellas-Boltà et al., 2013), Rano Kao (Seco et al., 2019) and Rano Aroi (Rull et al., 2015) for the last millennium (950 to 1850 CE). Droughts are depicted as gray bands. Red triangles indicate deforestation pulses and forest regeneration trends are indicated by blue arrows. Redrawn and modified from Rull (2020a). El - Easter Island.

Figure 27. Spatio-temporal deforestation patterns of Rano Aroi, Rano Kao and Rano Raraku areas and their potential drivers after Polynesian settlement, using the information from Fig. 26. Forest cover was estimated by palm pollen percentage. The blue arrow indicates the relocation of the cultural core of the Rapanui society from Rano Raraku to Rano Kao. Redrawn and modified from Rull (2020a).

Figure 28. Panoramic view of Rano Kao showing the position of the ceremonial village of Orongo, on top of the SW crater crest, and the location of formerly cultivated terraces (yellow line), as documented by paleoecological records (Horrocks et al., 2012b). 


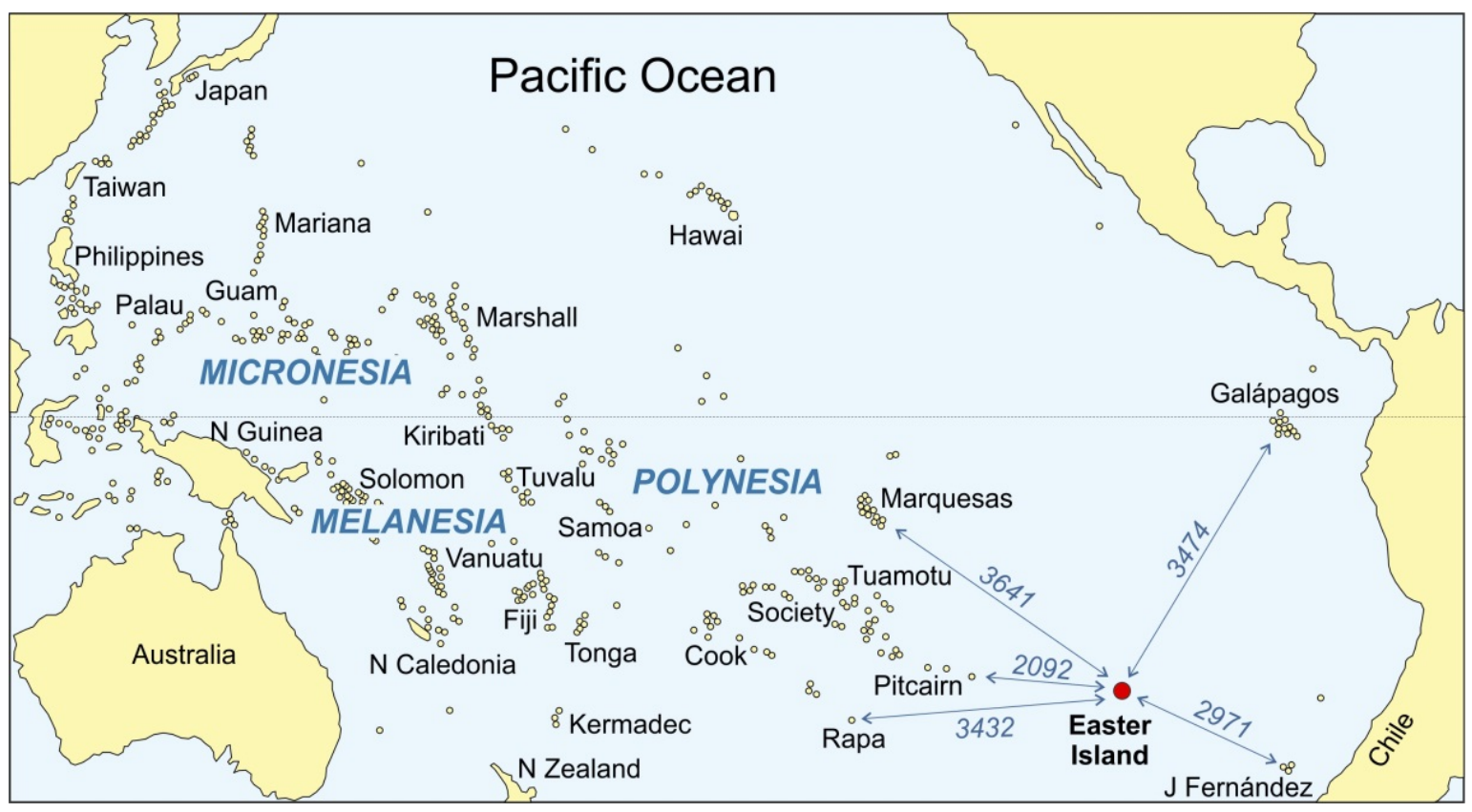

Figure 1 


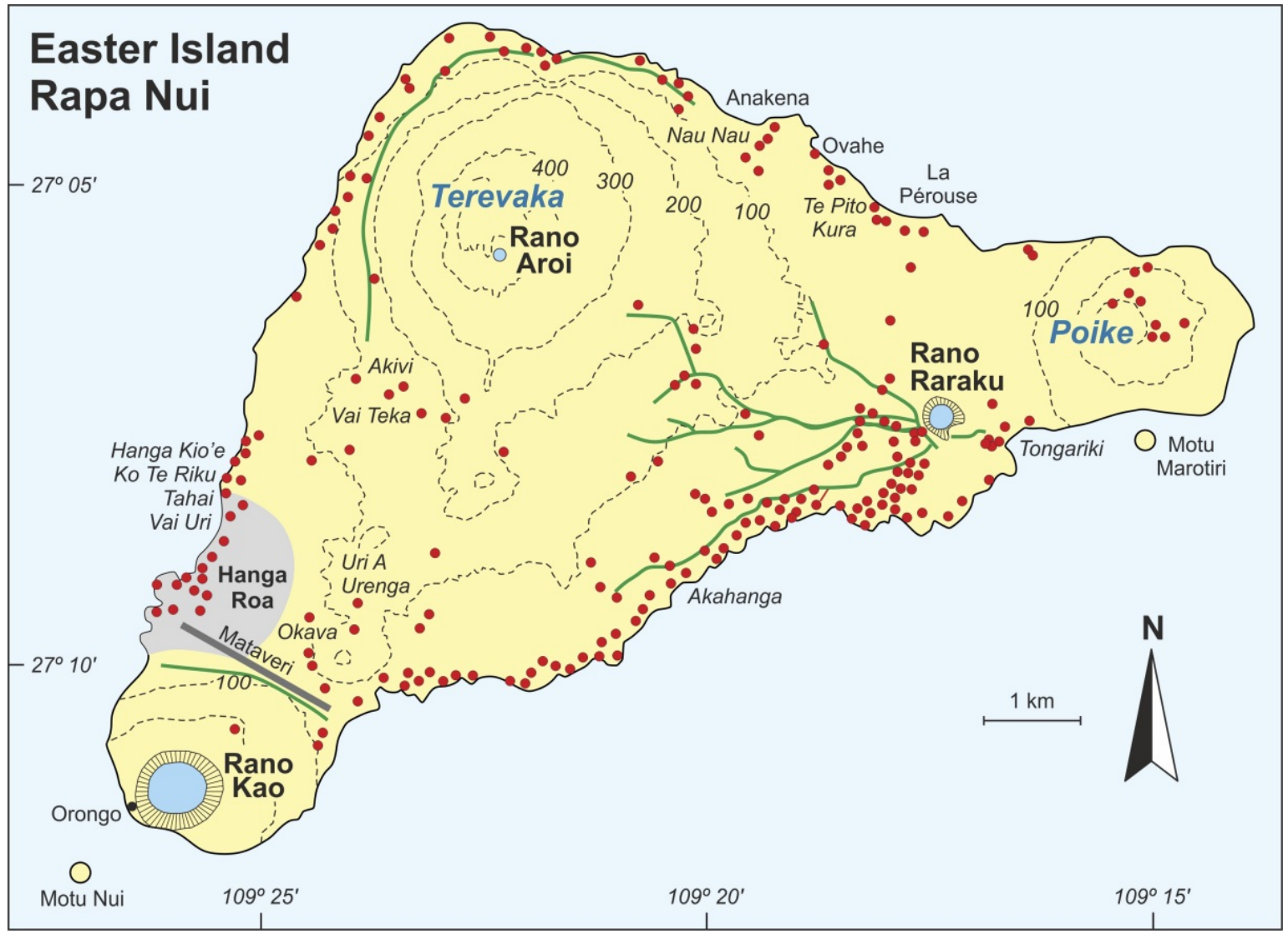

Figure 2 


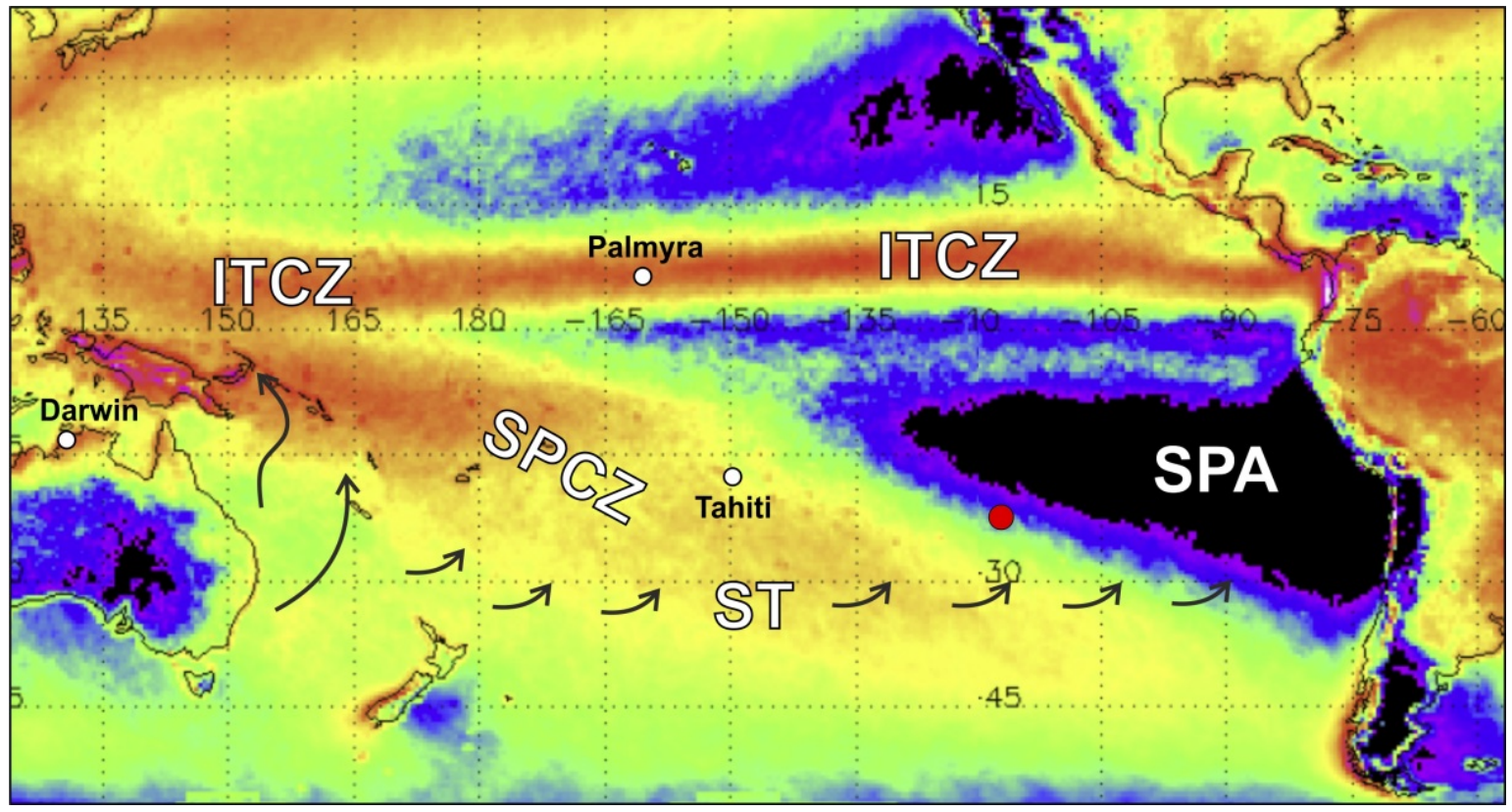

Figure 3 

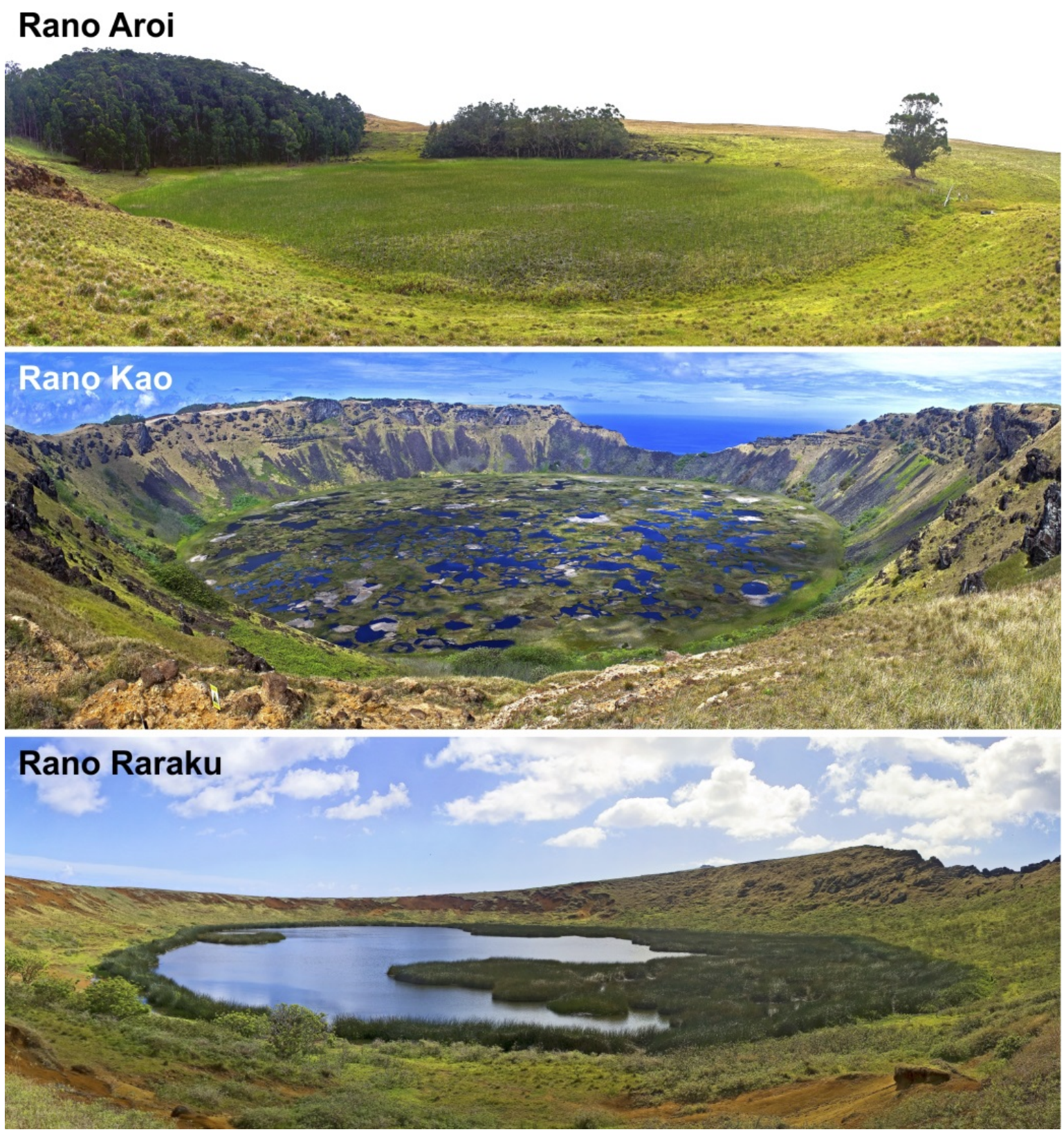

Figure 4 


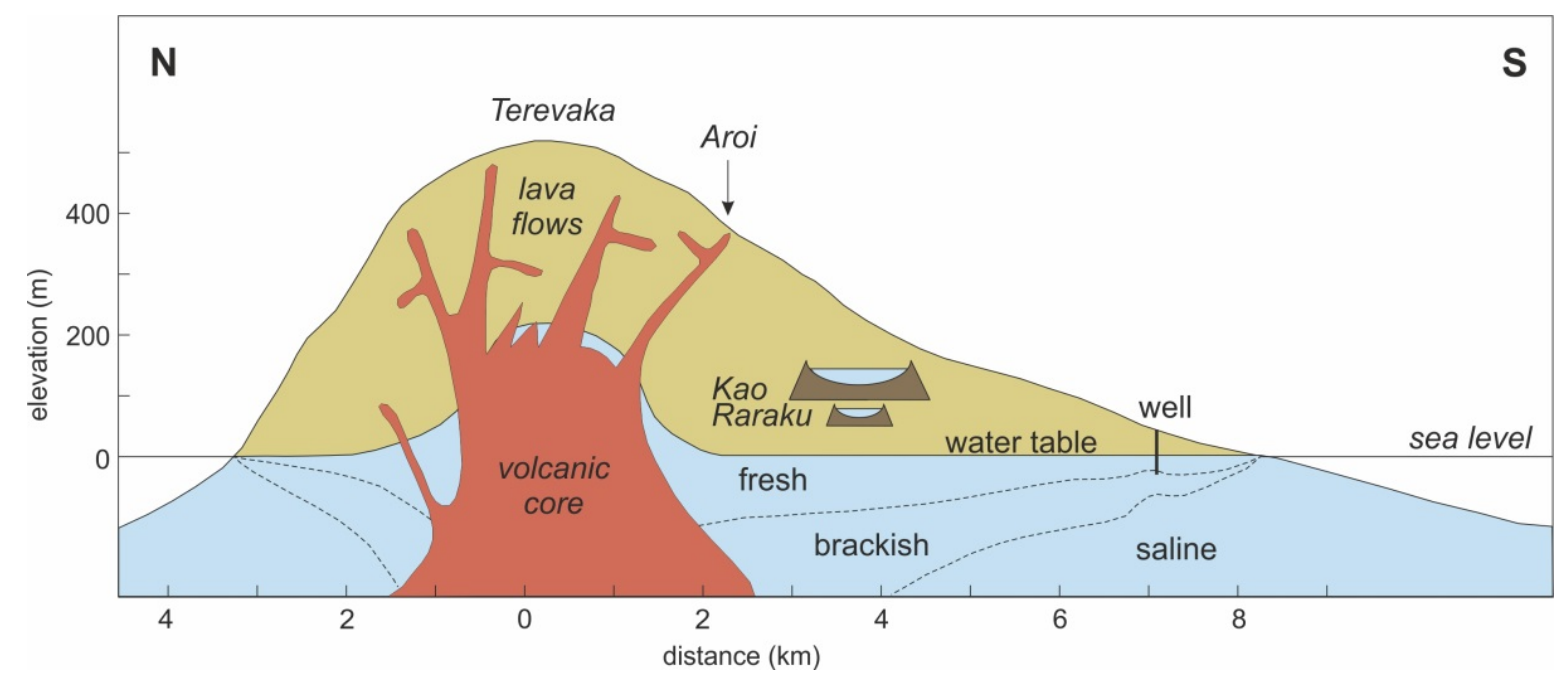

Figure 5 


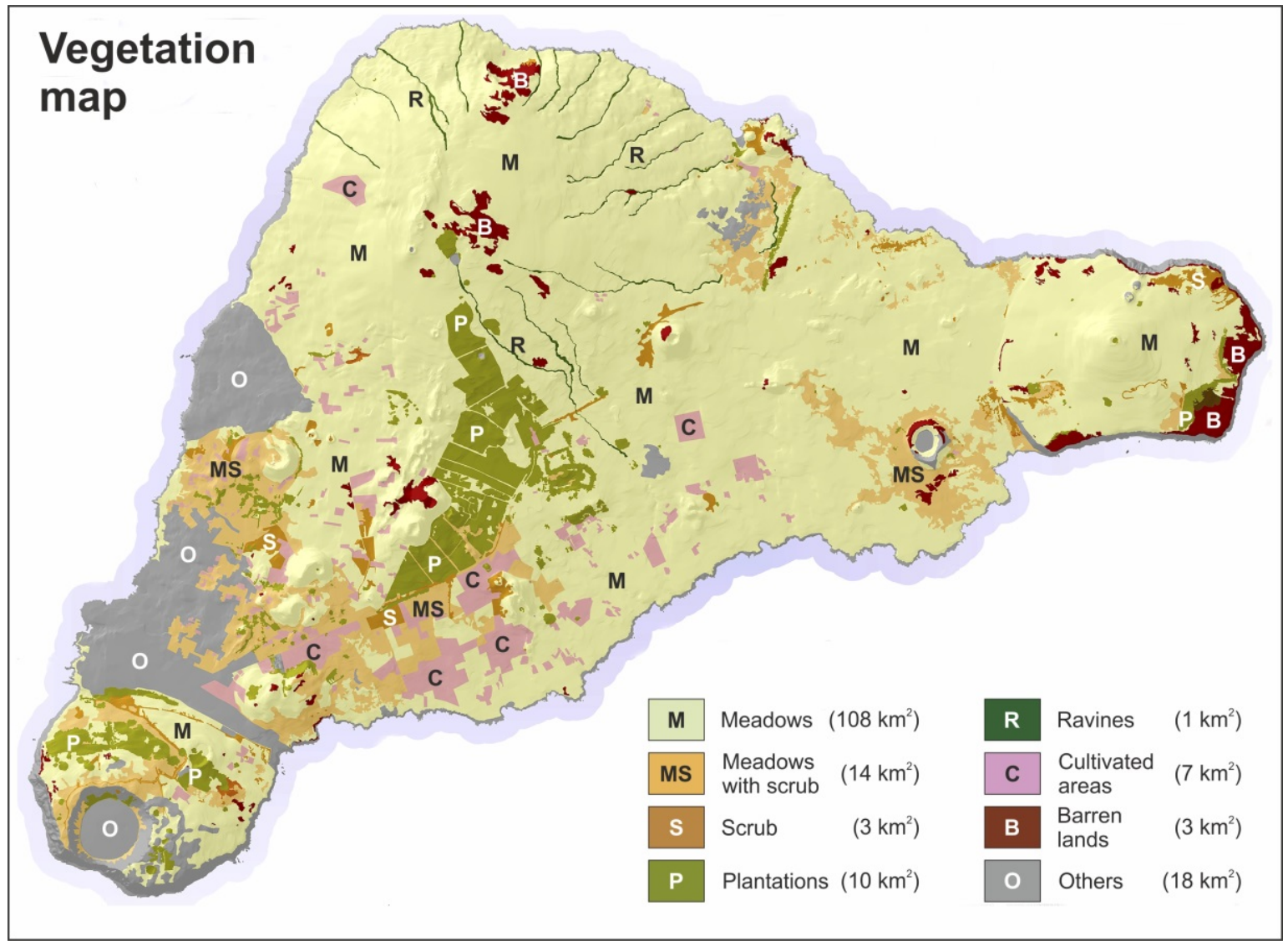

Figure 6 

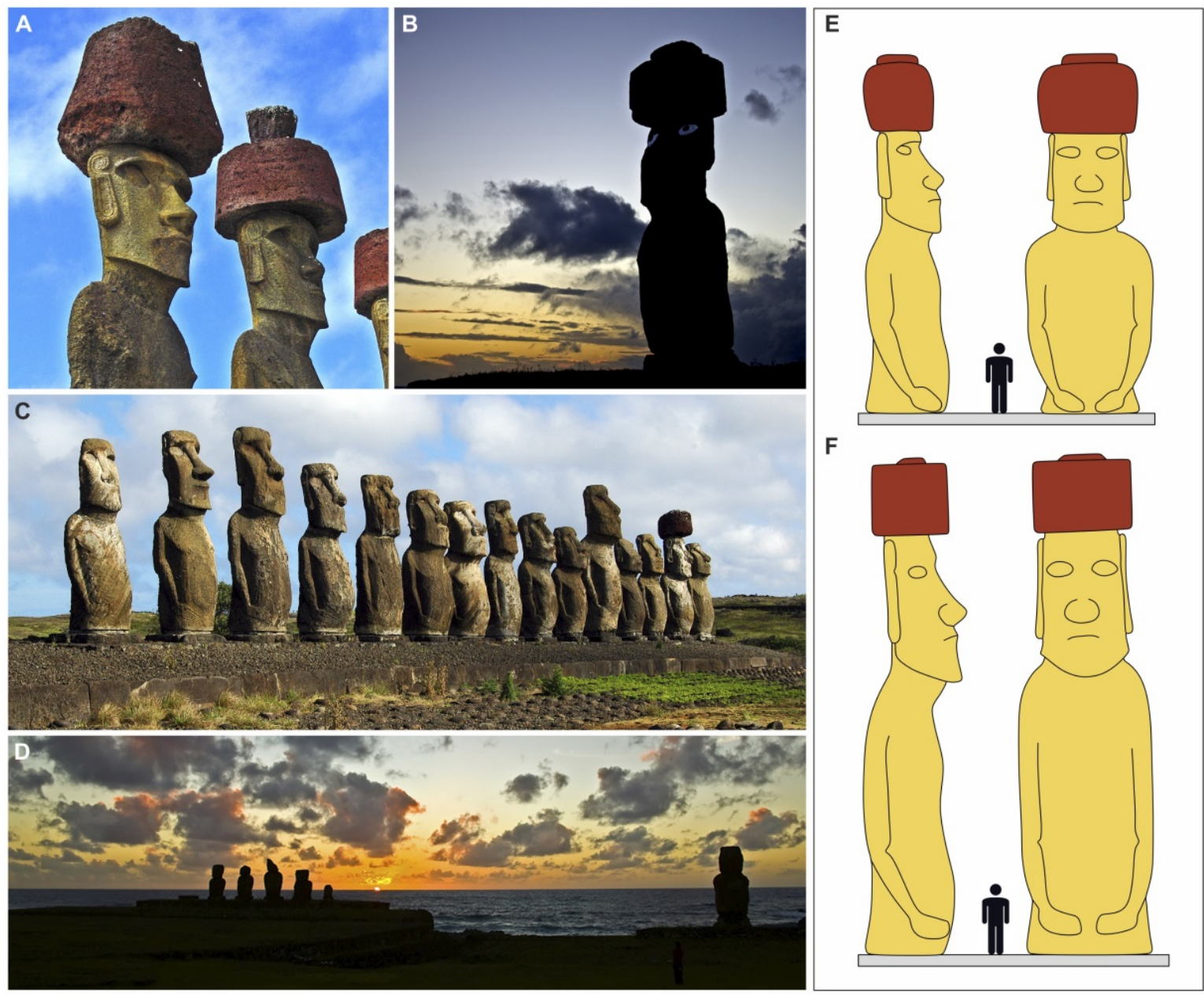

Figure 7 

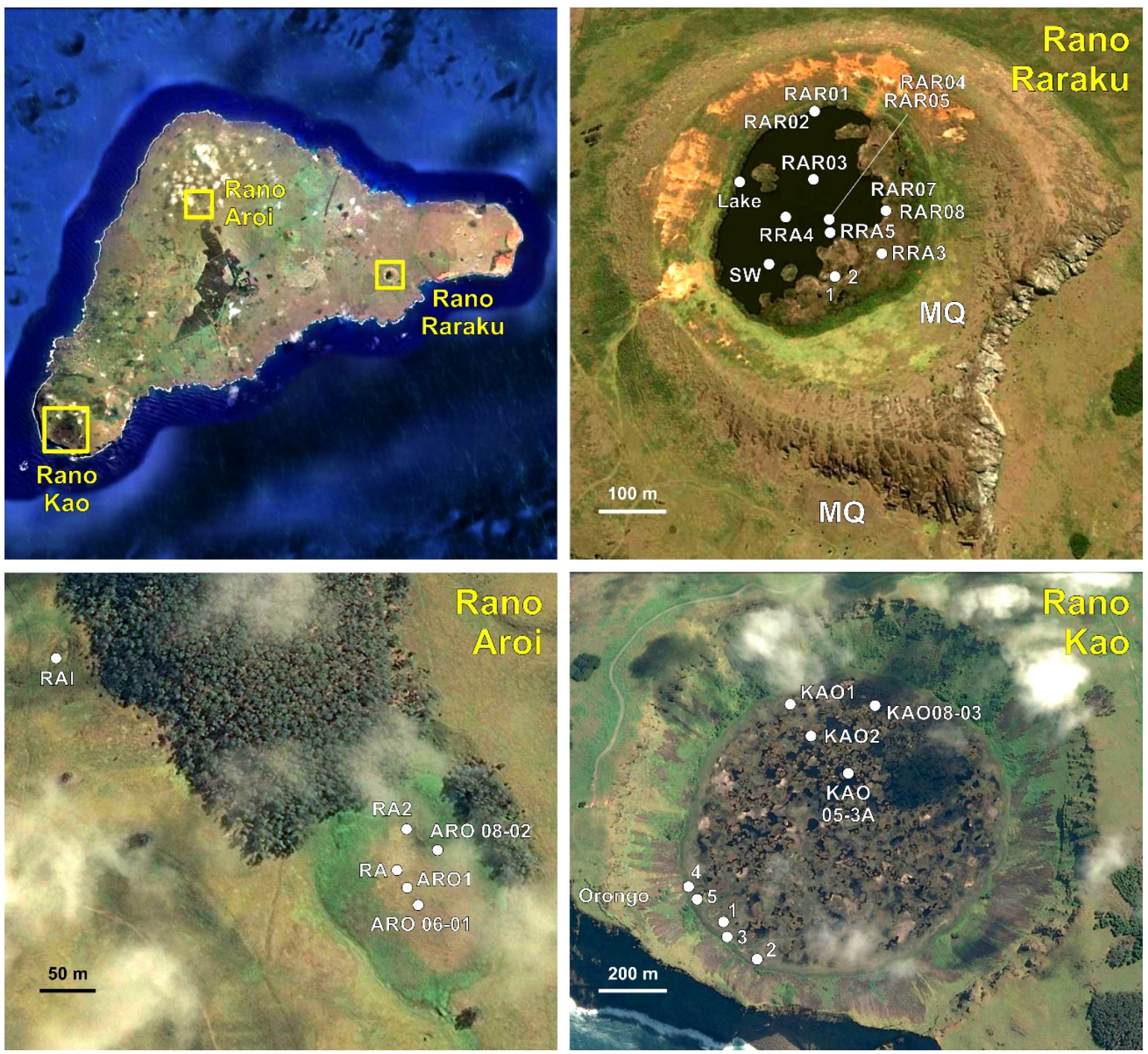

Figure 8 
This paper is a non-peer reviewed EarthArXiv preprint

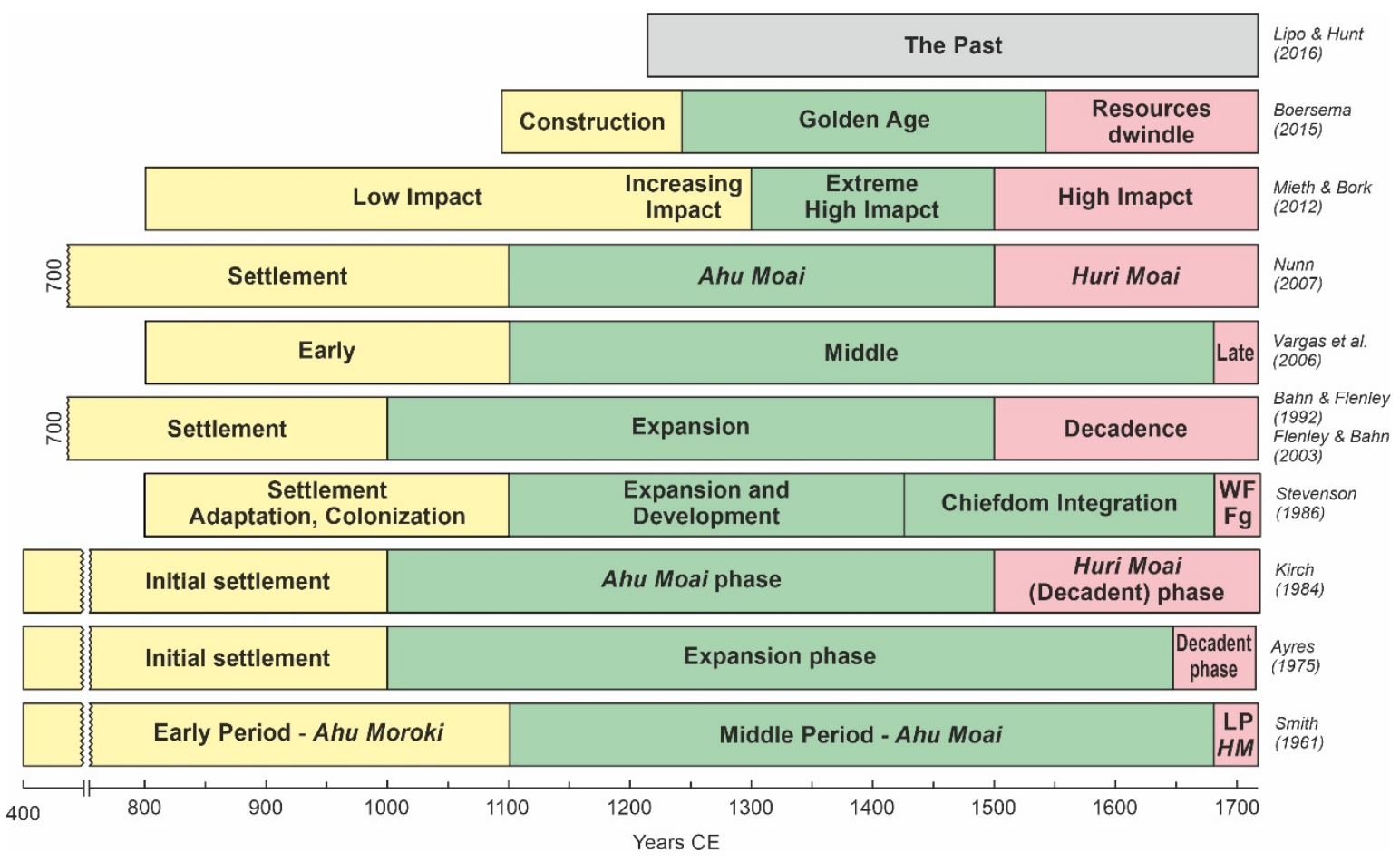

Figure 9 


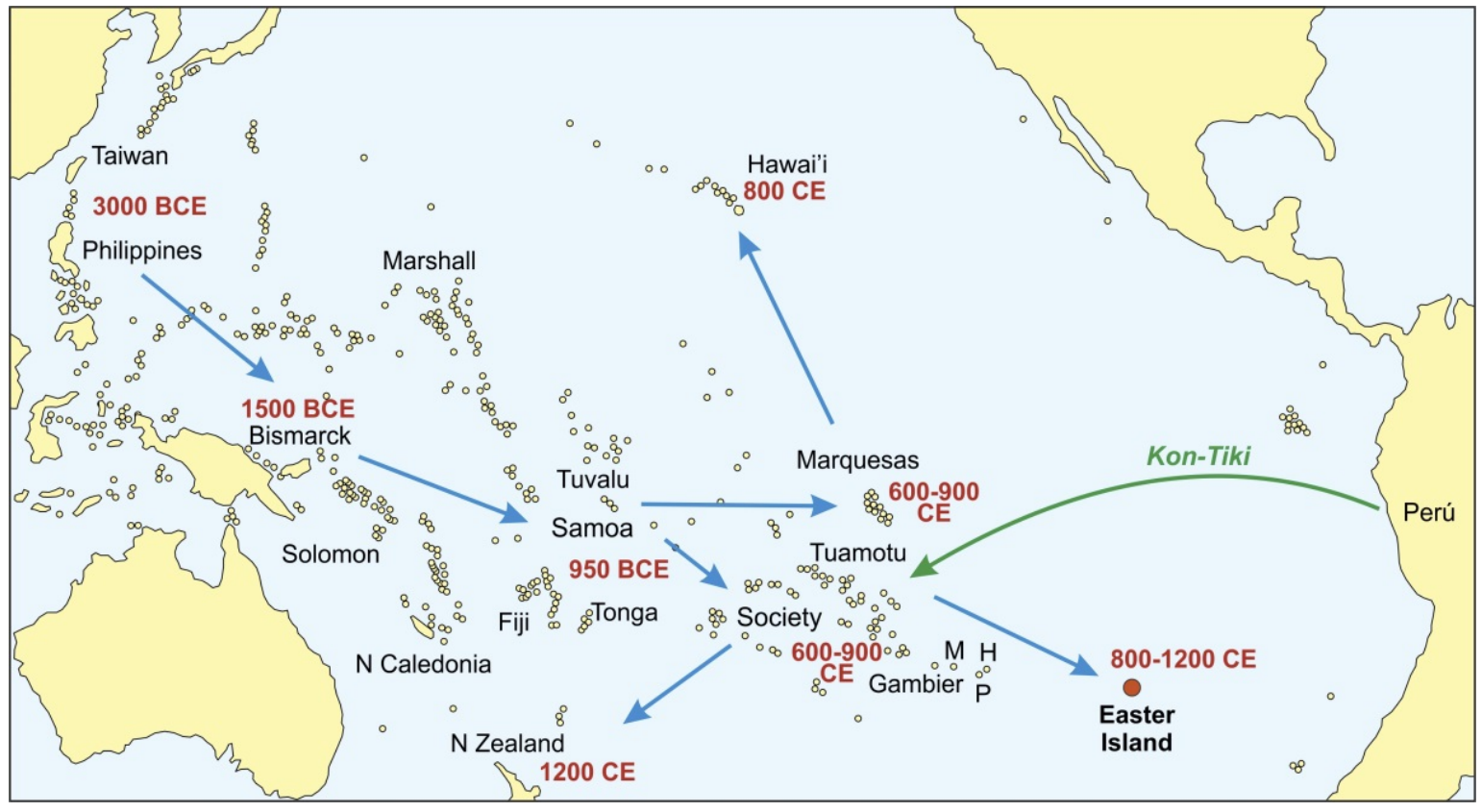

Figure 10 


\section{Rano Raraku - Core RRA3}

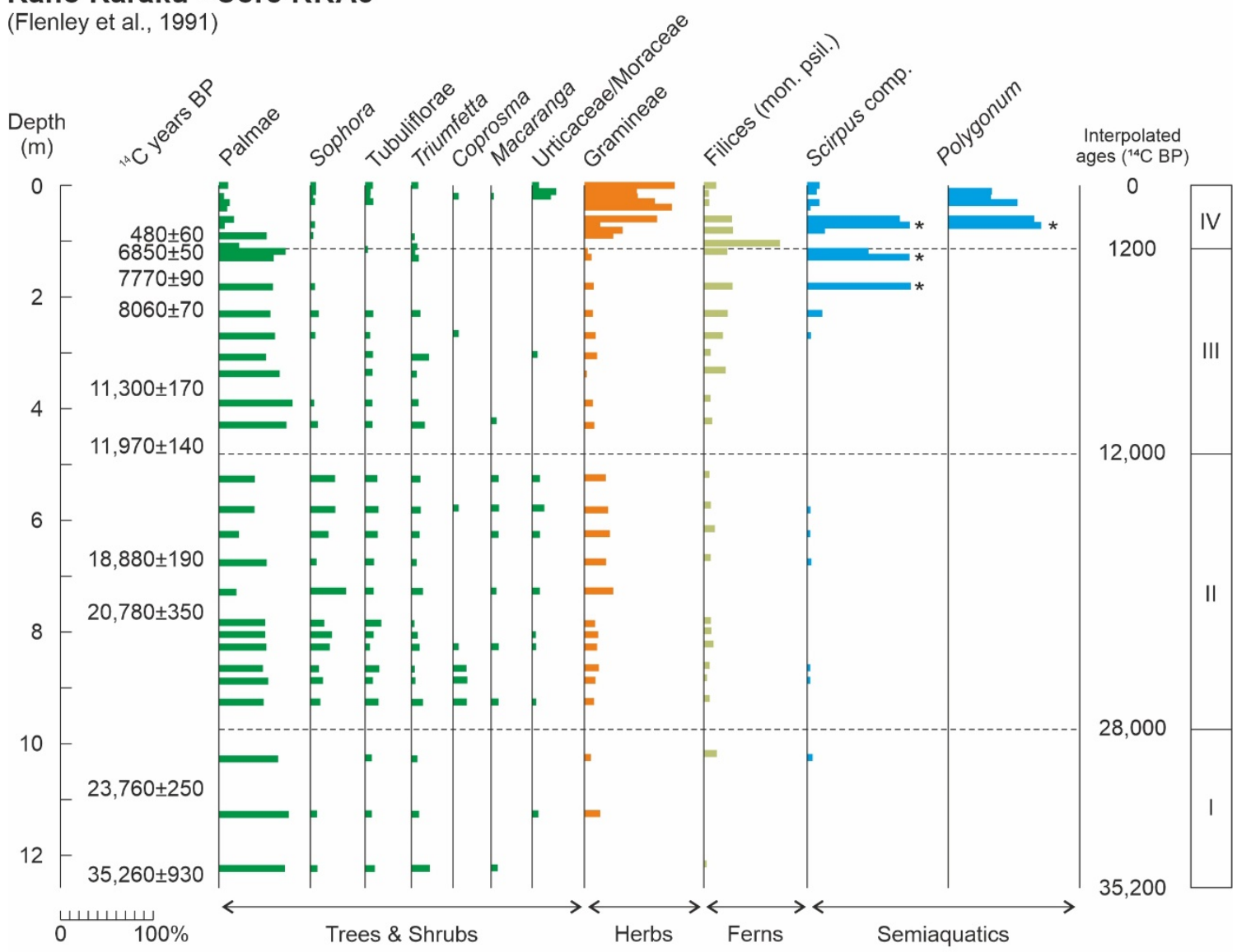

Rano Kao - Core KAO1

(Flenley et al., 1991)
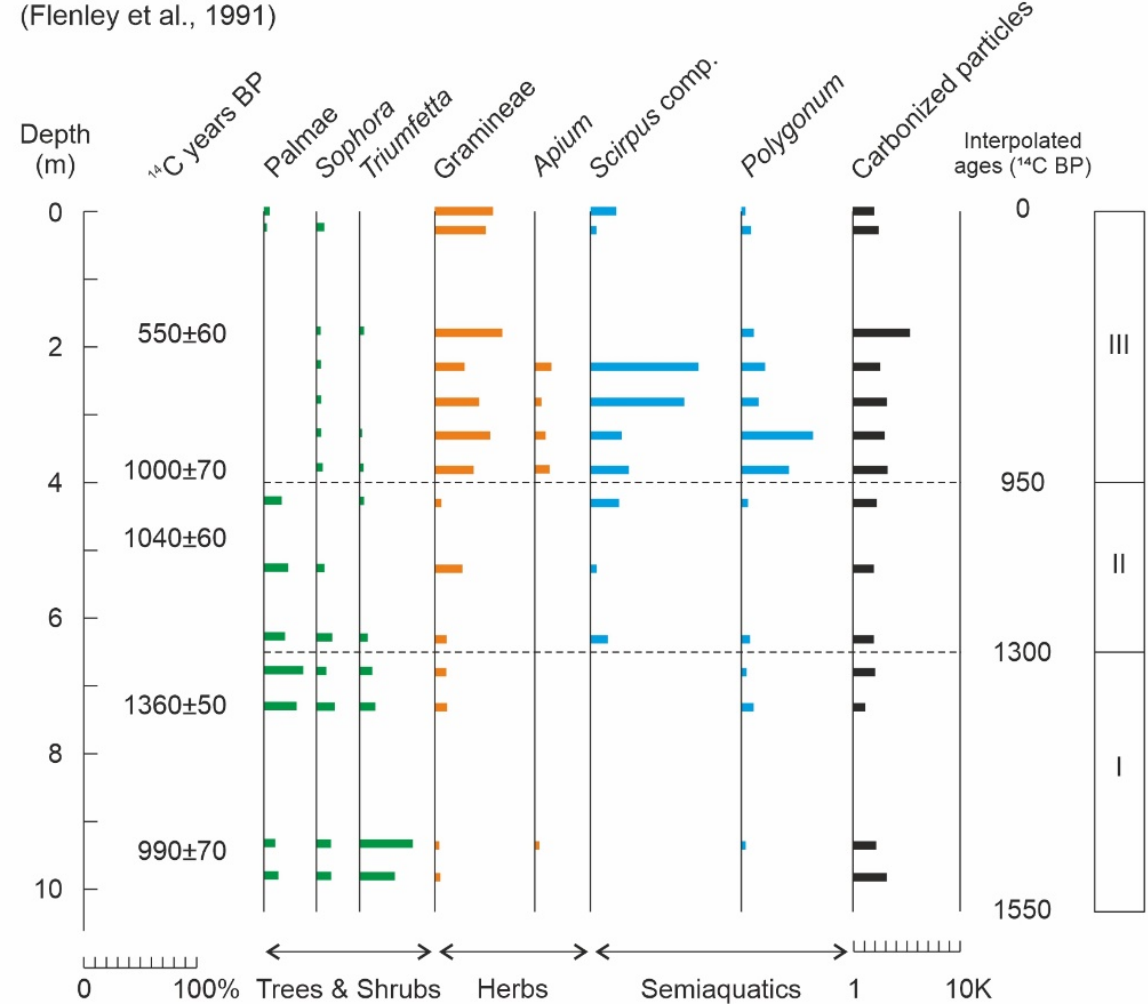

Figure 11 


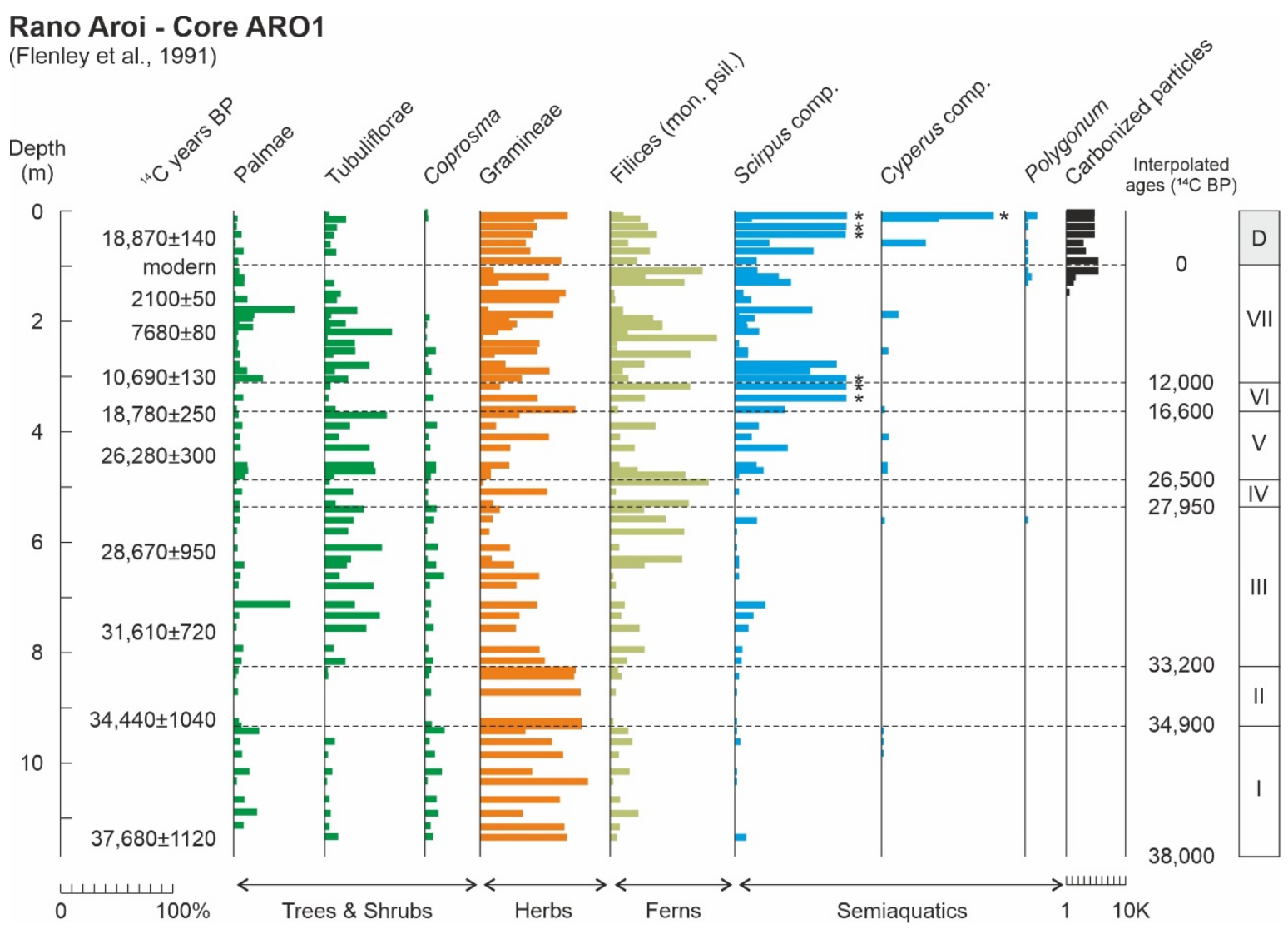

Figure 12 
This paper is a non-peer reviewed EarthArXiv preprint

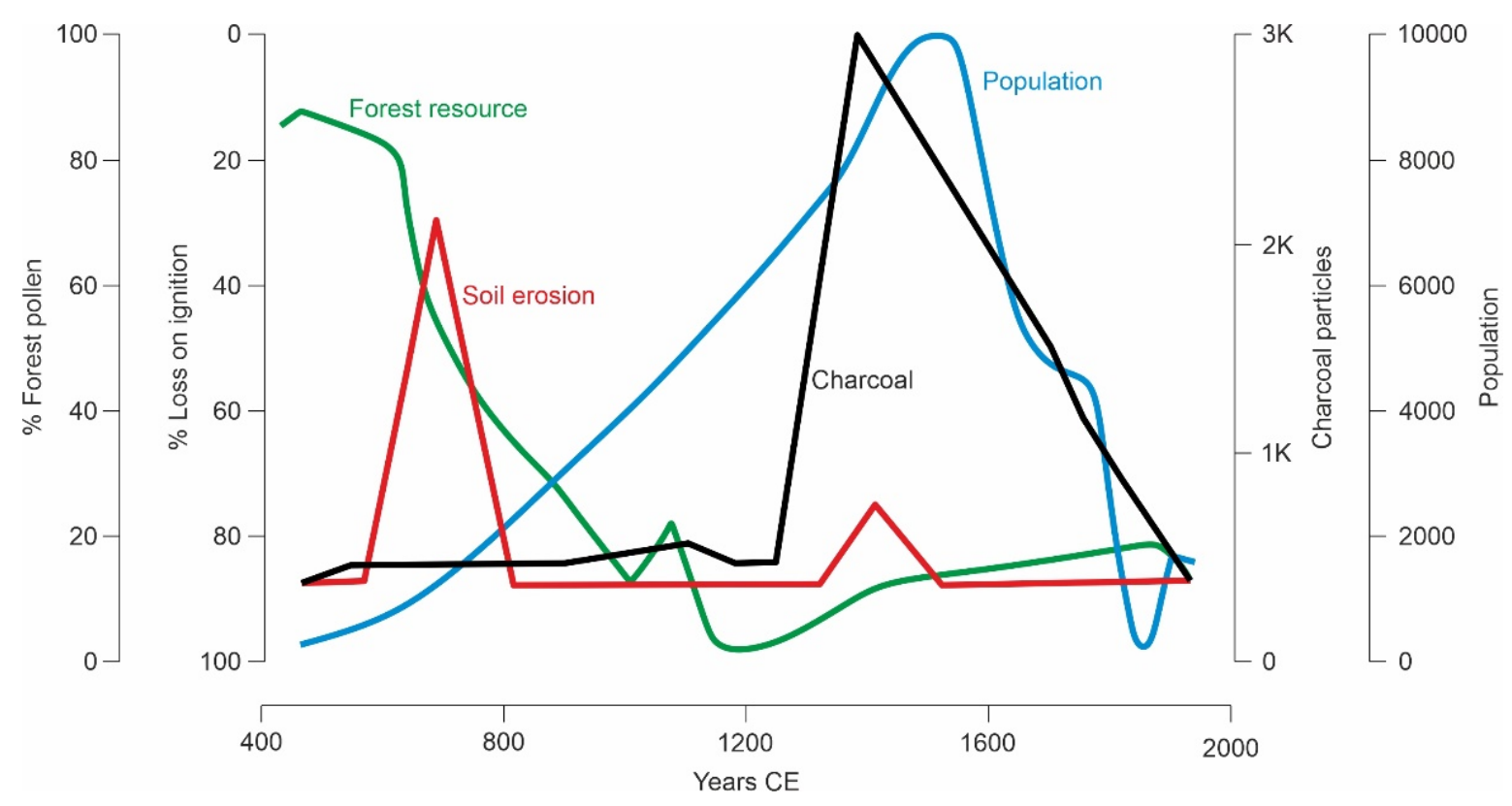

Figure 13 
This paper is a non-peer reviewed EarthArXiv preprint

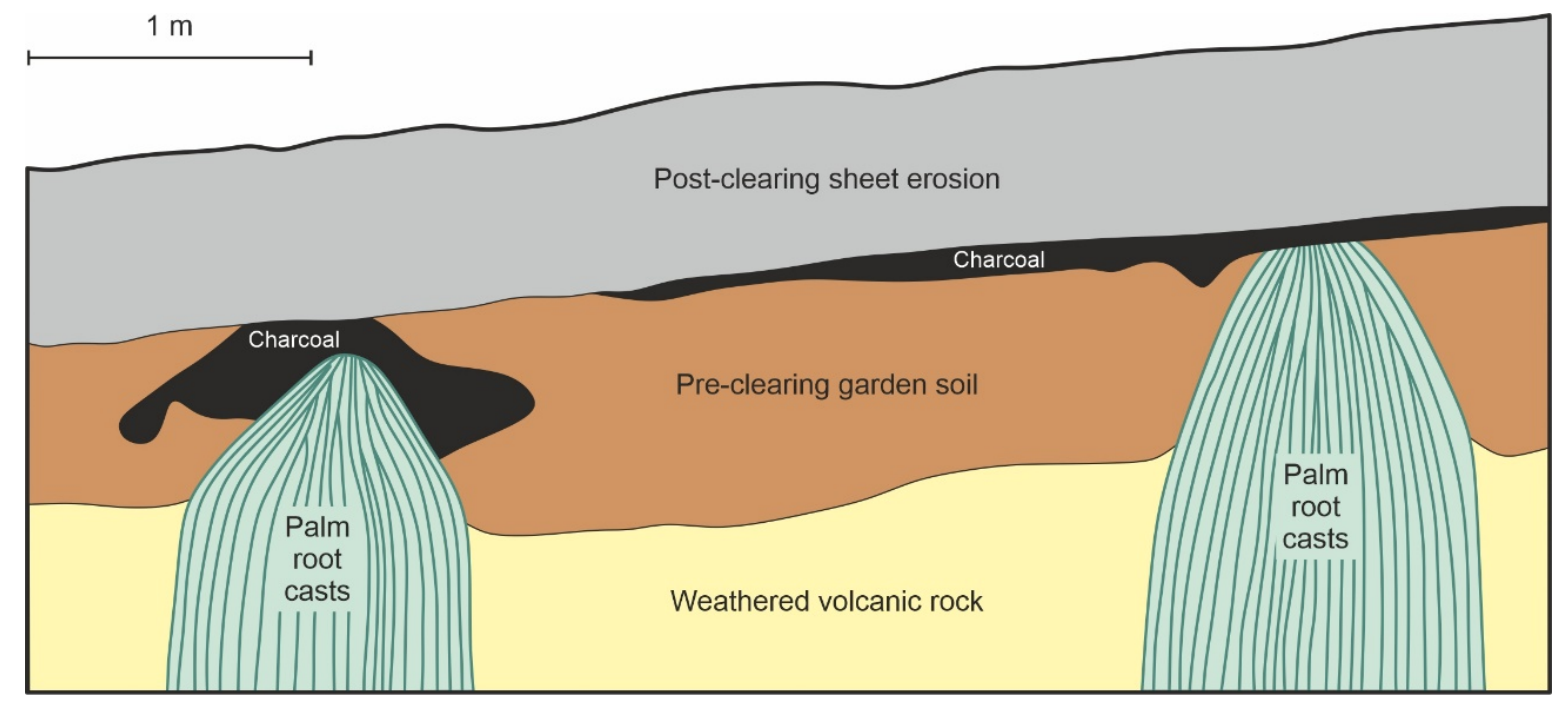

Figure 14 
This paper is a non-peer reviewed EarthArXiv preprint

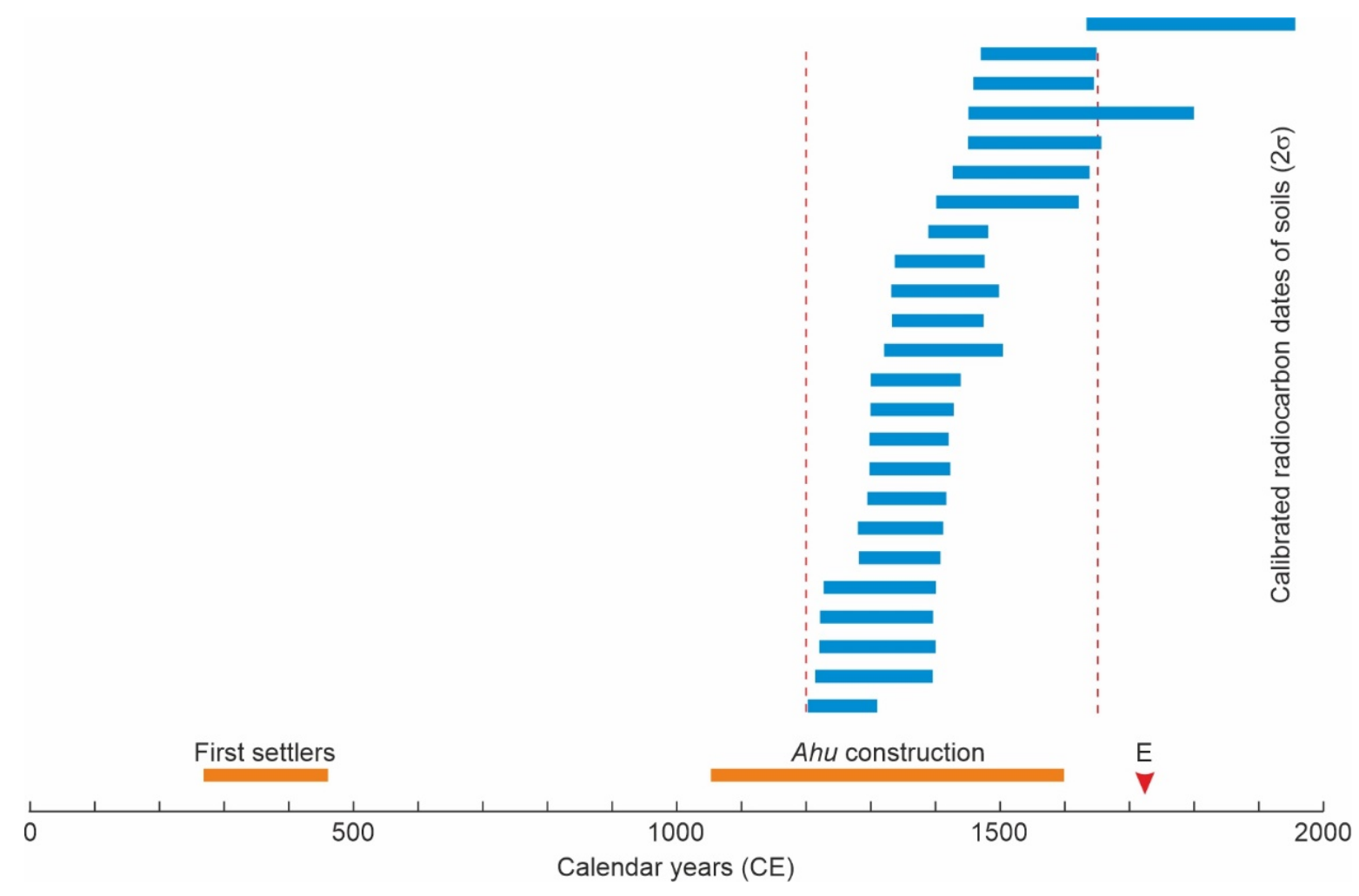

Figure 15 
Rano Raraku - Core \#1

(Mann et al., 2008)
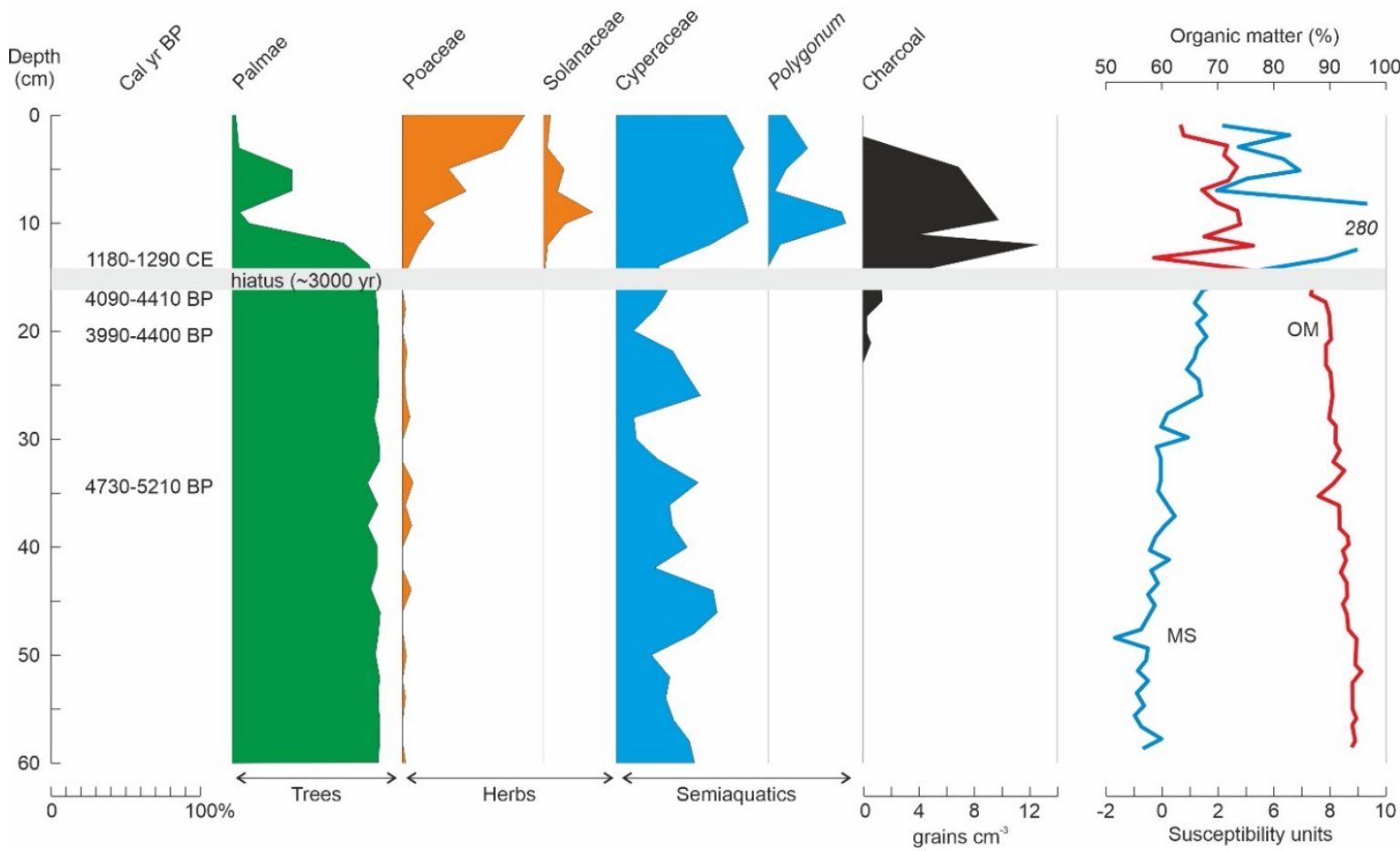

Figure 16 
This paper is a non-peer reviewed EarthArXiv preprint

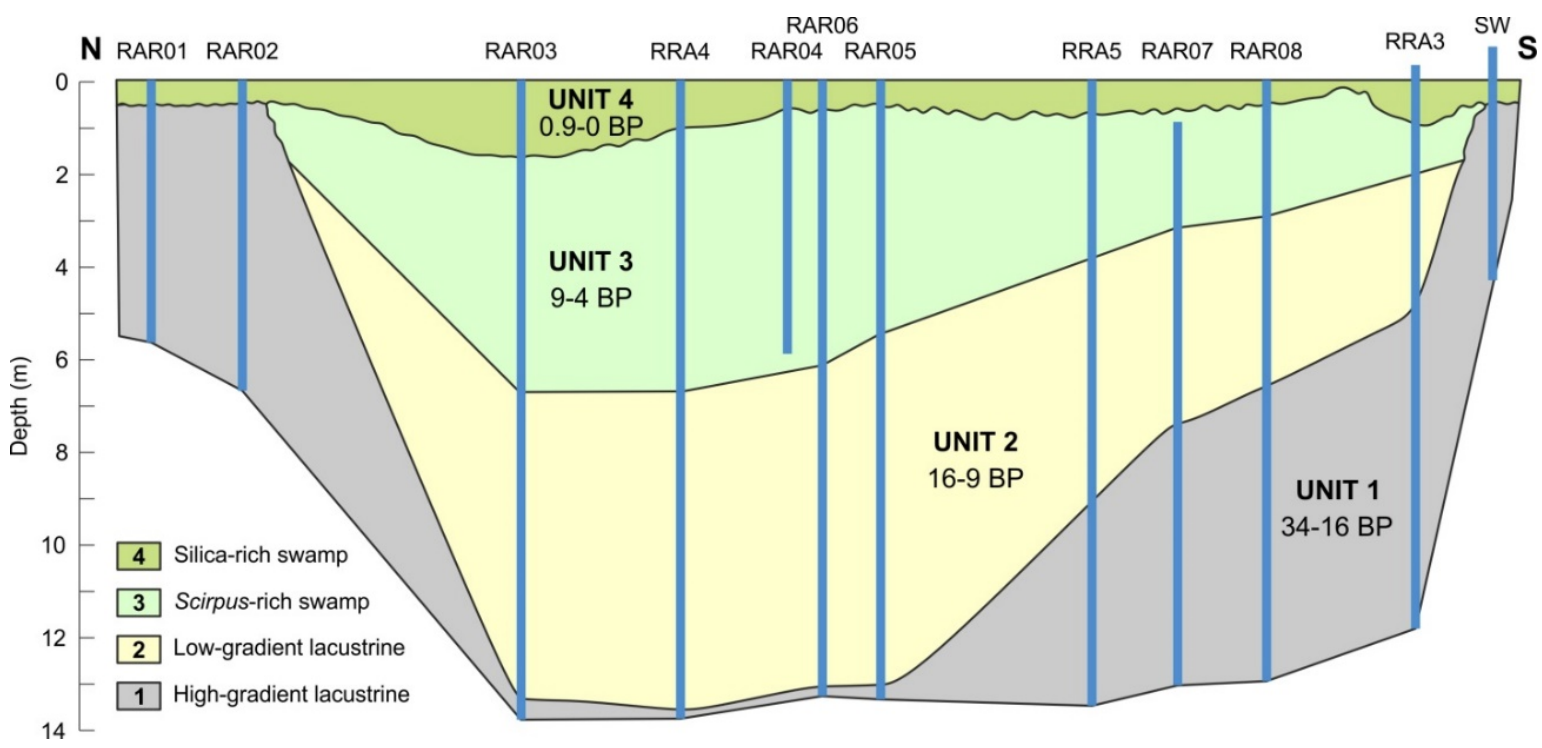

Figure 17 


\section{Rano Kao - Core KAO2}

(Butler \& Flenley, 2010)

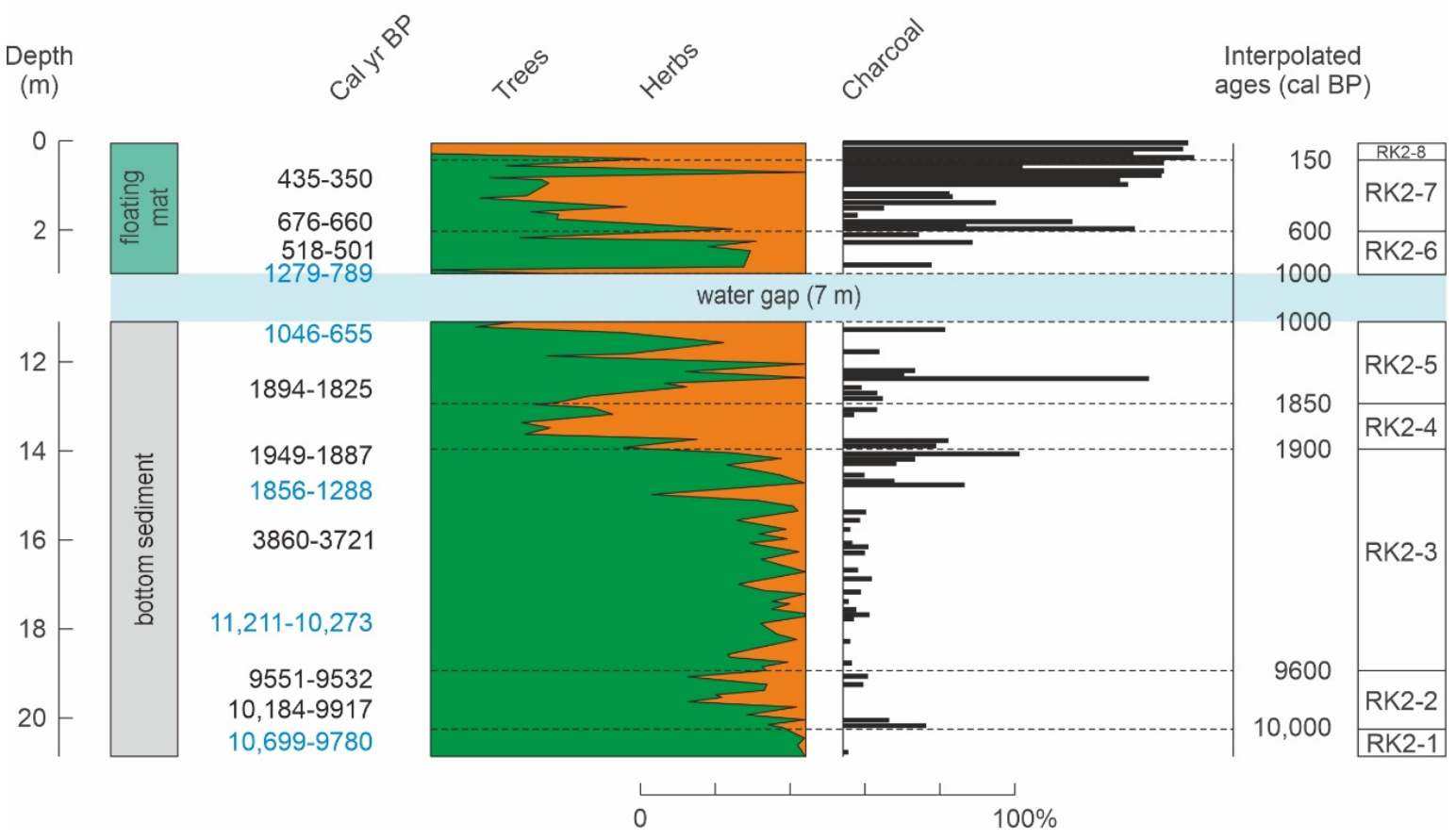

Figure 18 
Rano Kao - Core 1

(Horrocks et al., 2013)
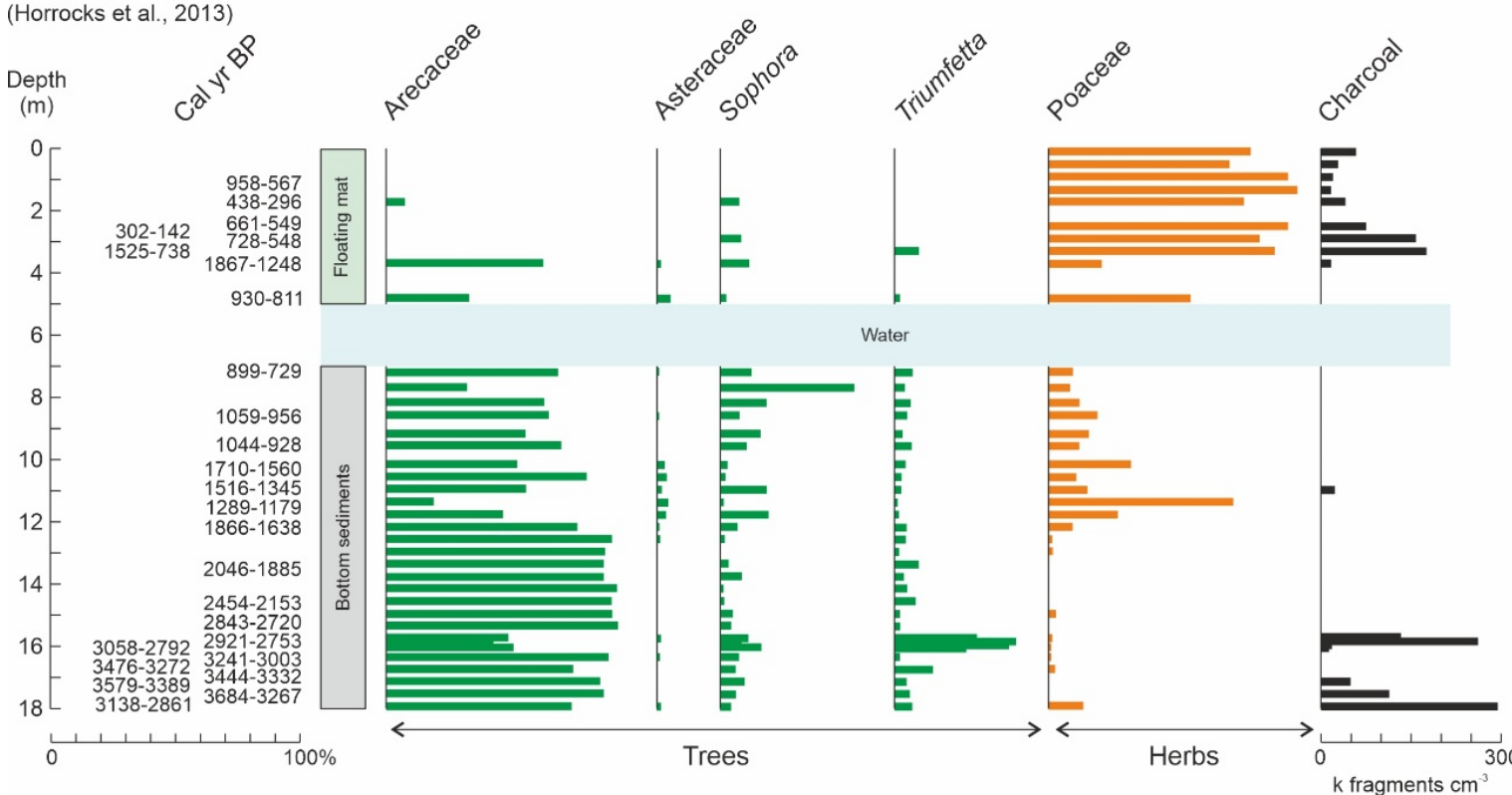

Rano Raraku - Core Lake

(Horrocks et al., 2012a)
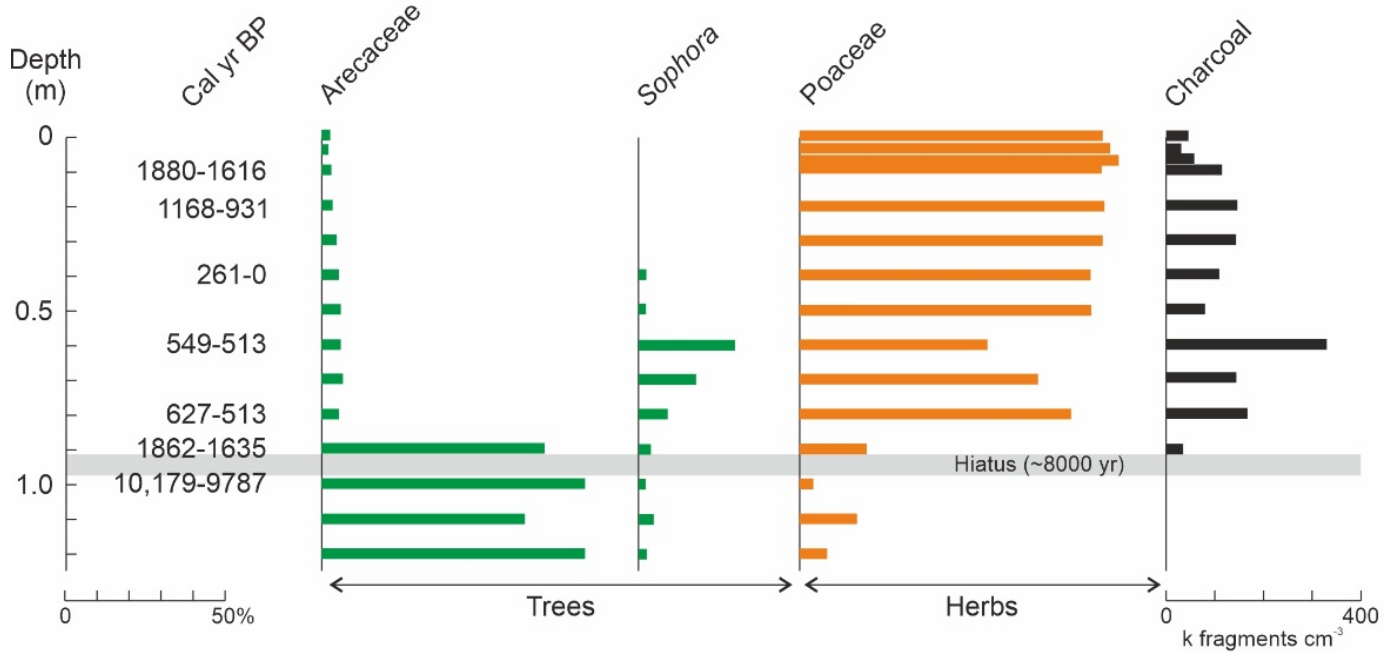

Rano Aroi - Core RA

(Horrocks et al., 2015)

Depth
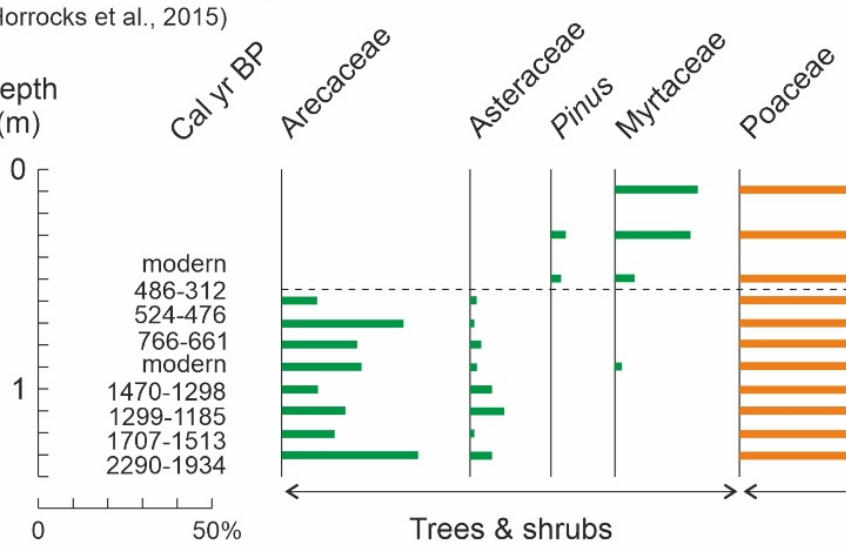

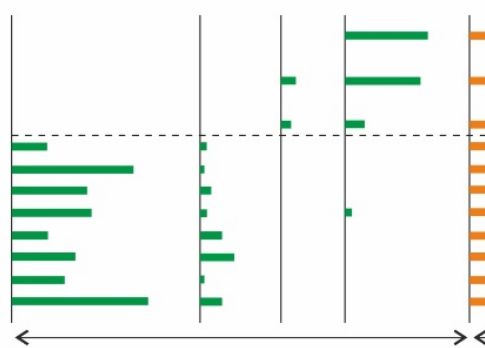

Trees \& shrubs

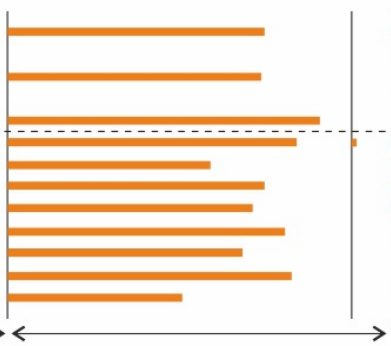

Herbs
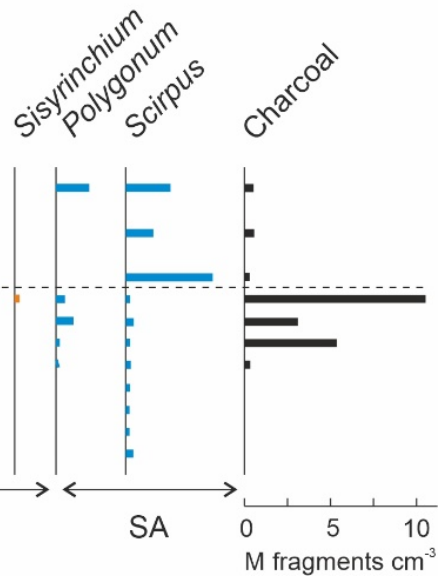

Figure 19 
This paper is a non-peer reviewed EarthArXiv preprint

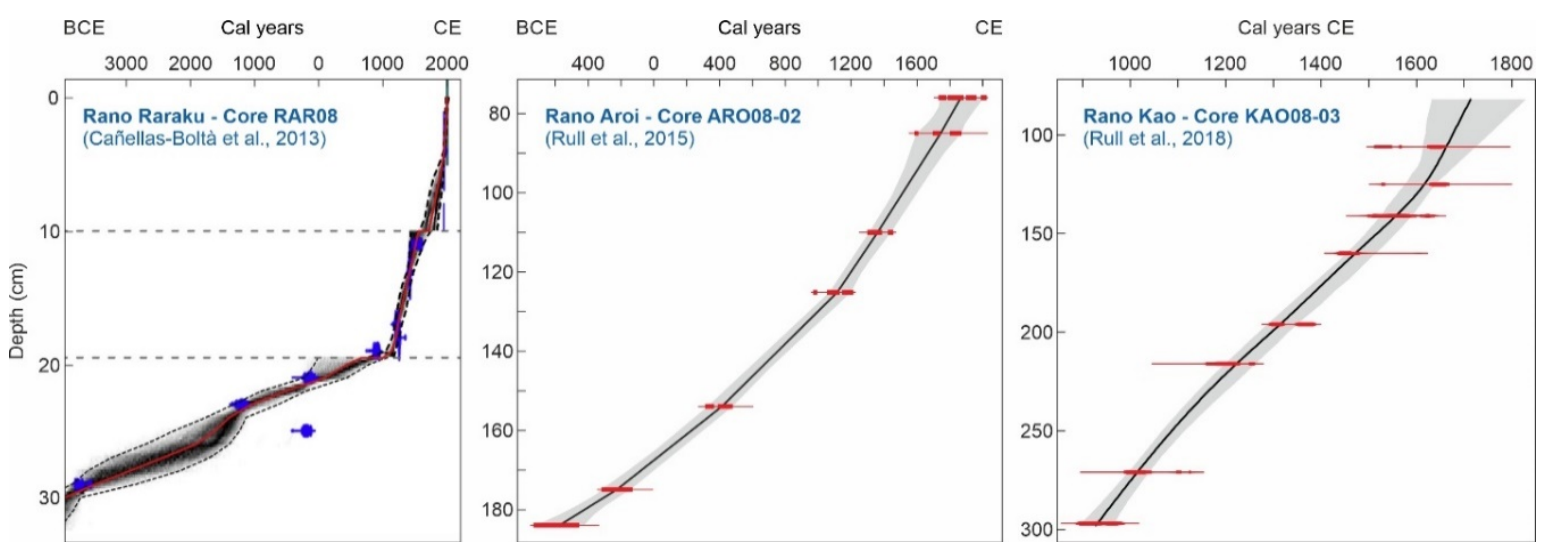

Figure 20 


\section{Rano Raraku - Core RAR08}

(Cañellas-Boltà et al., 2013)

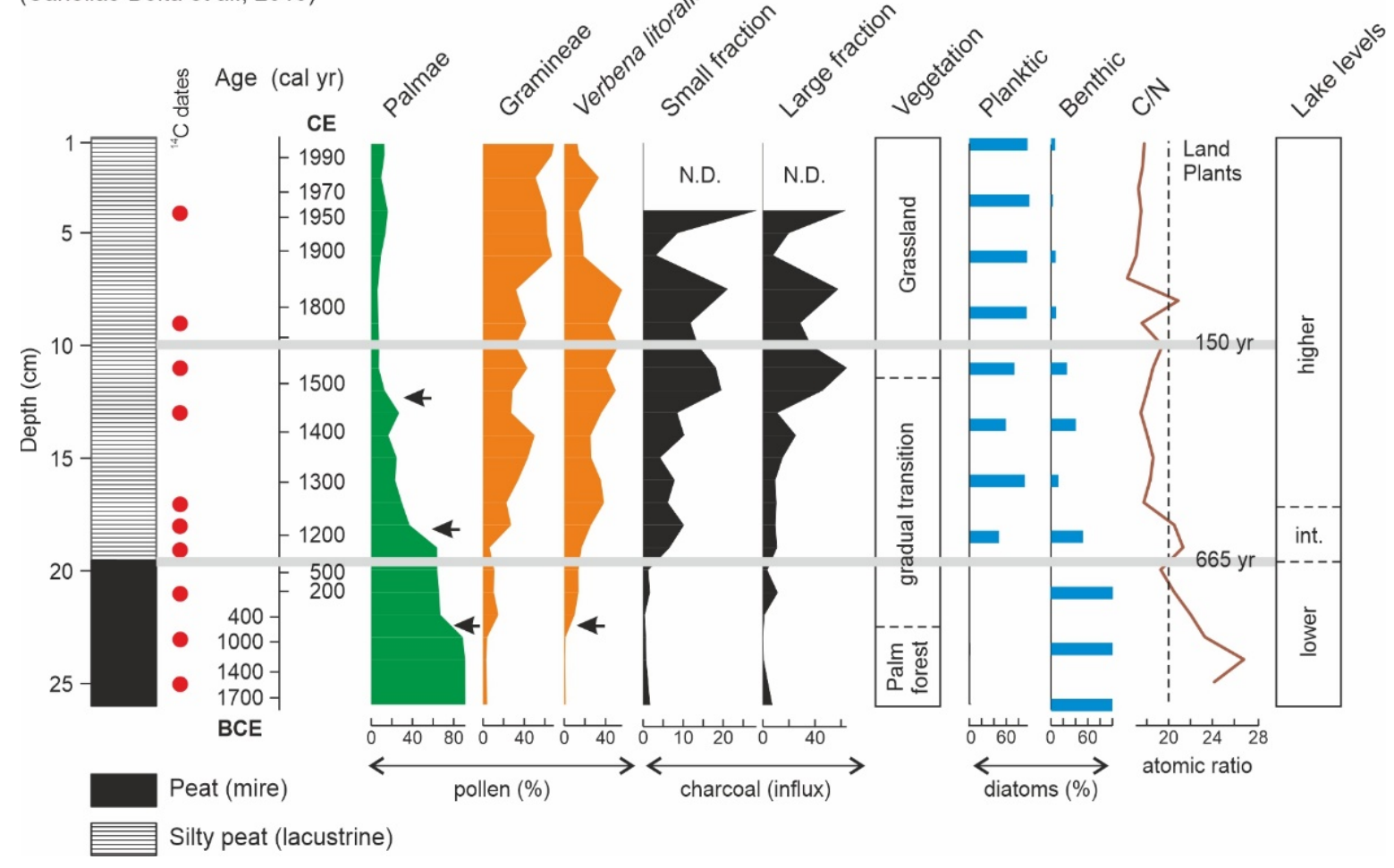

Figure 21 

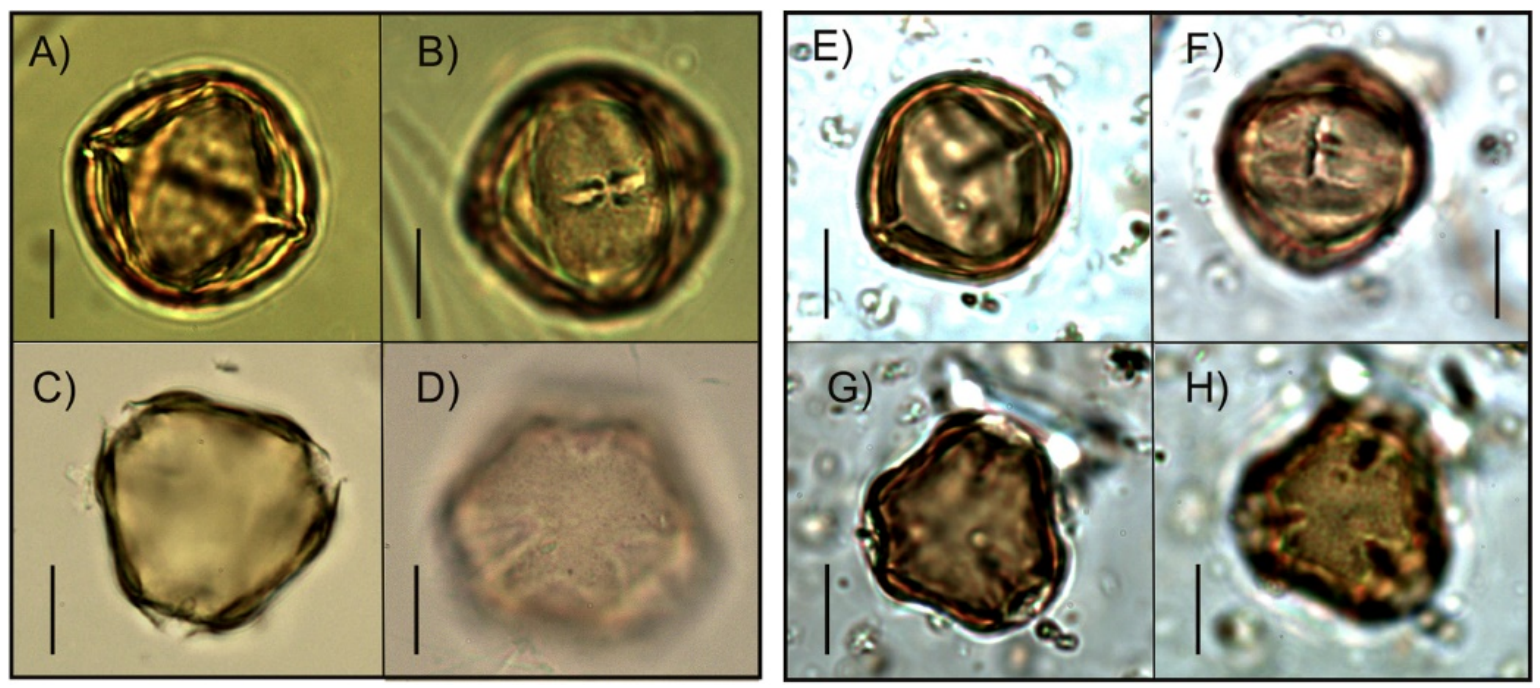

Figure 22 
Rano Aroi - Core ARO08 02

(Rull et al., 2015)

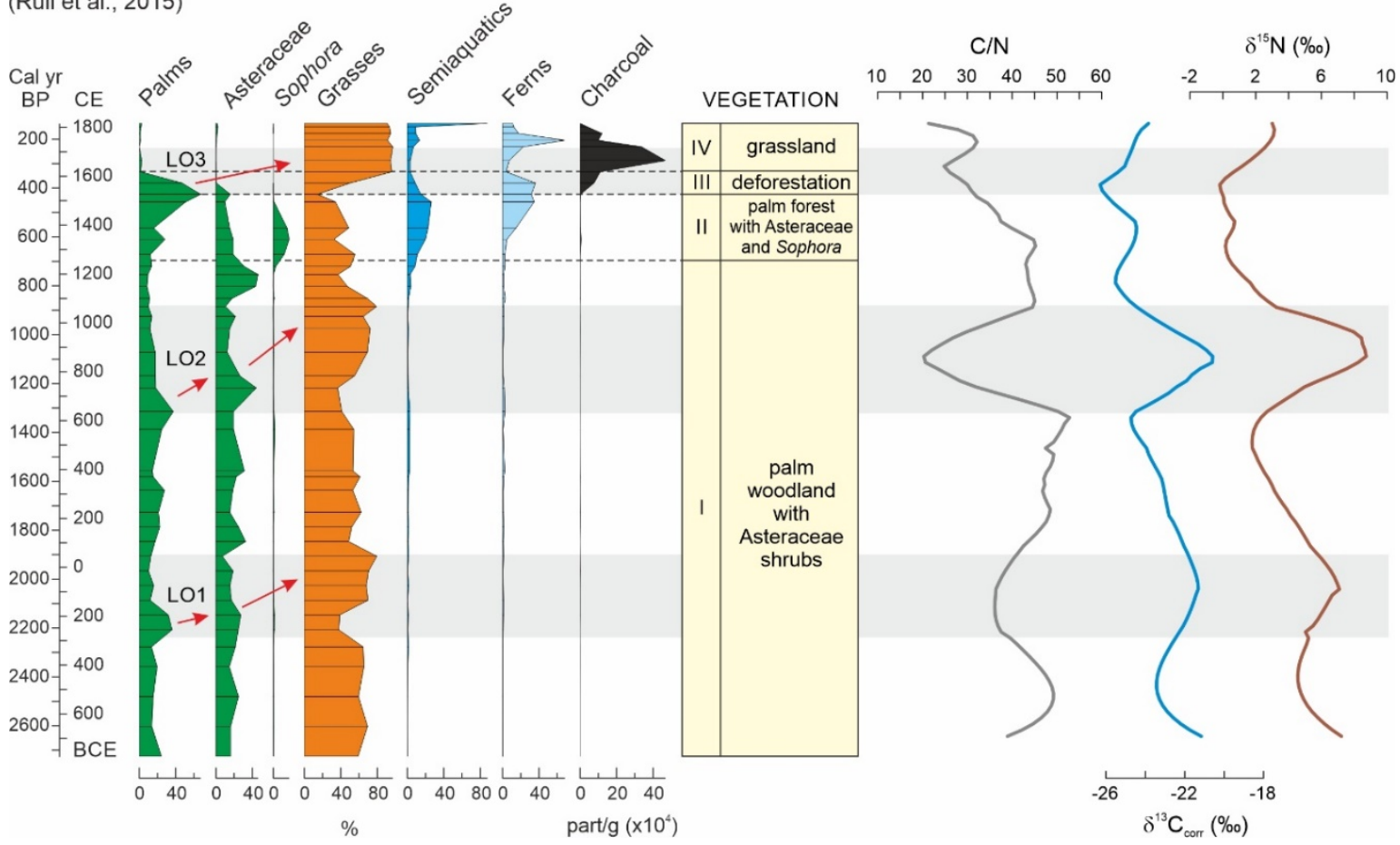

Figure 23 
Rano Kao - Core KAO08-03

(Seco et al., 2019)

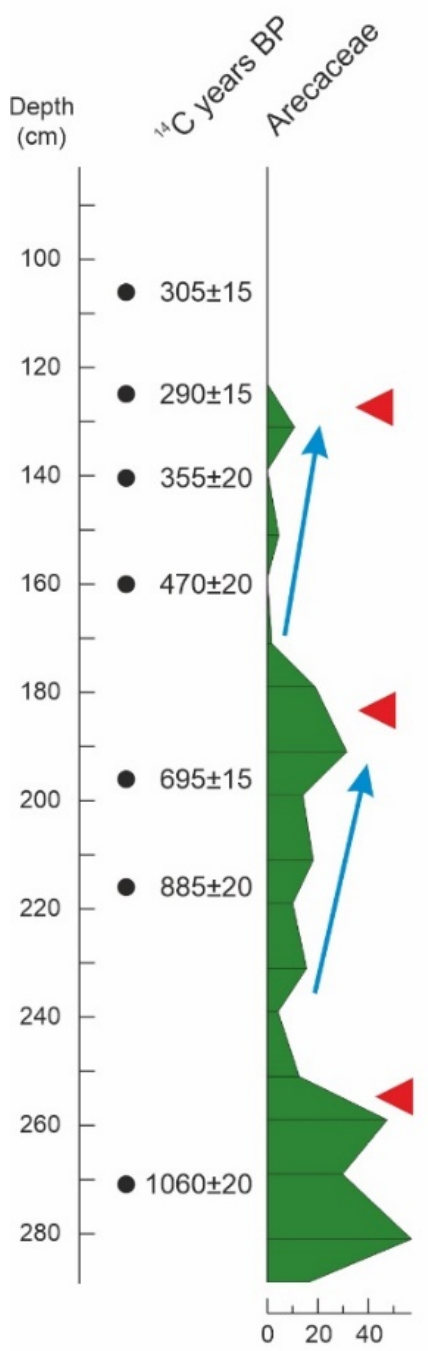

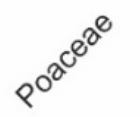
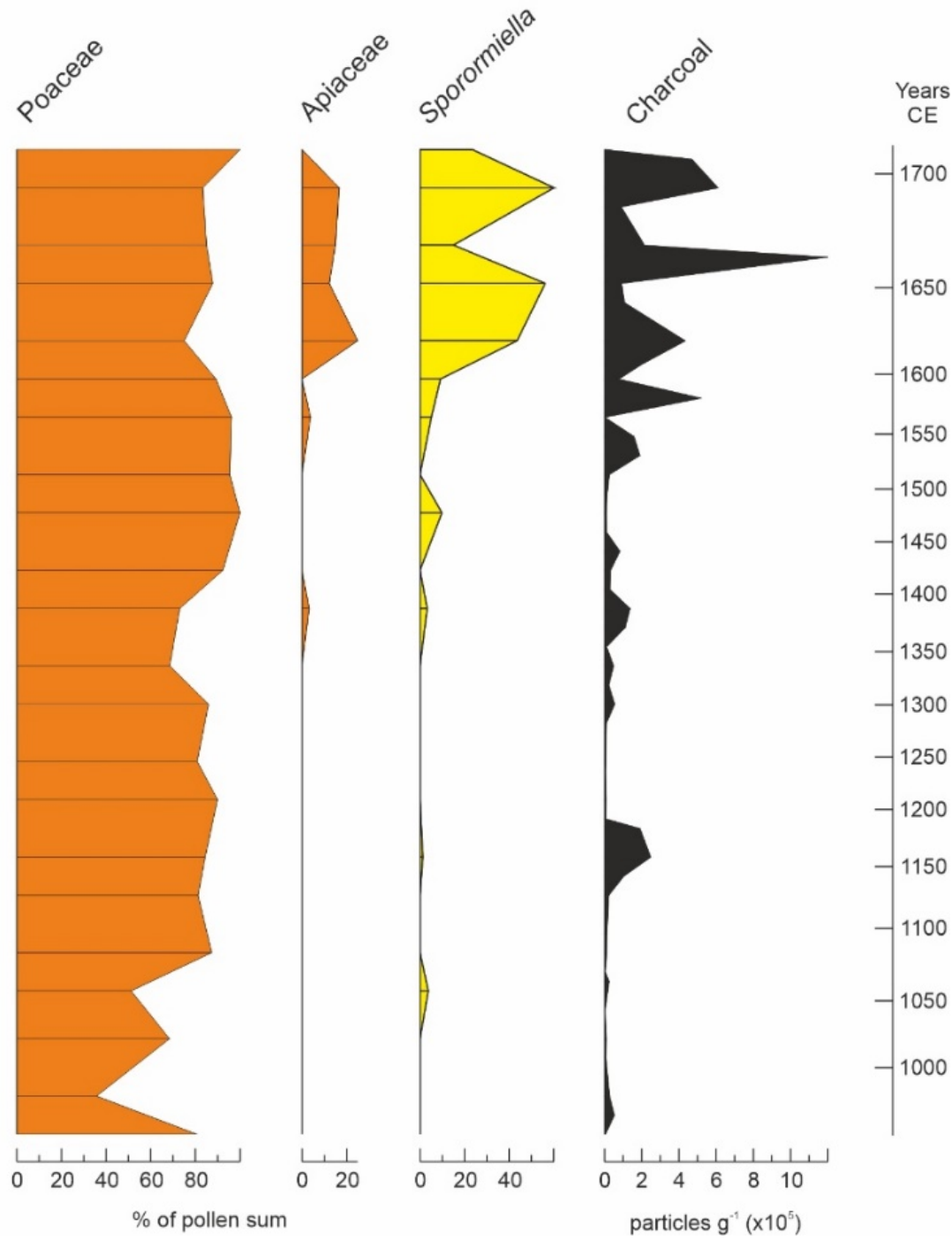

Figure 24 


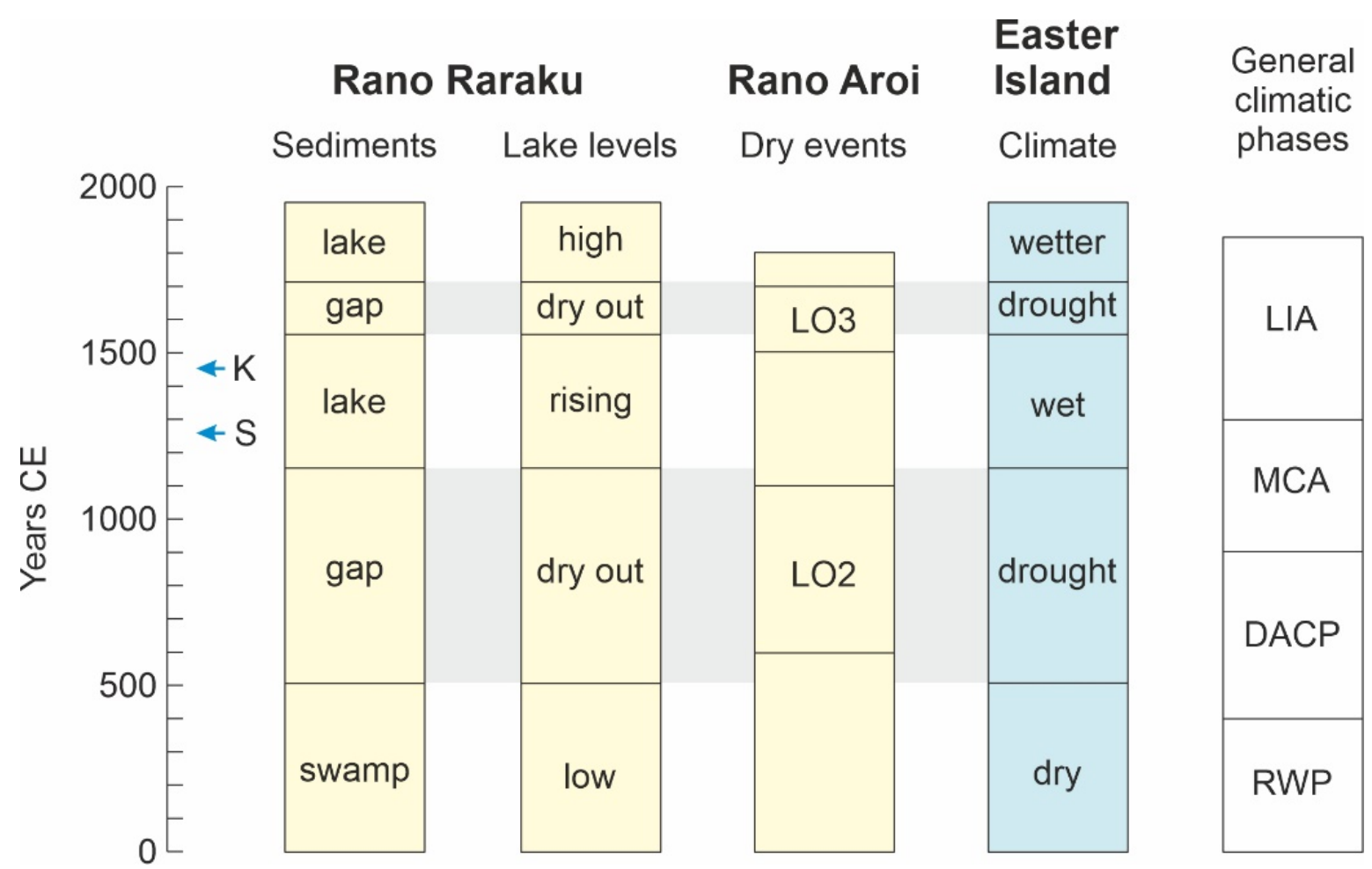

Figure 25 
This paper is a non-peer reviewed EarthArXiv preprint

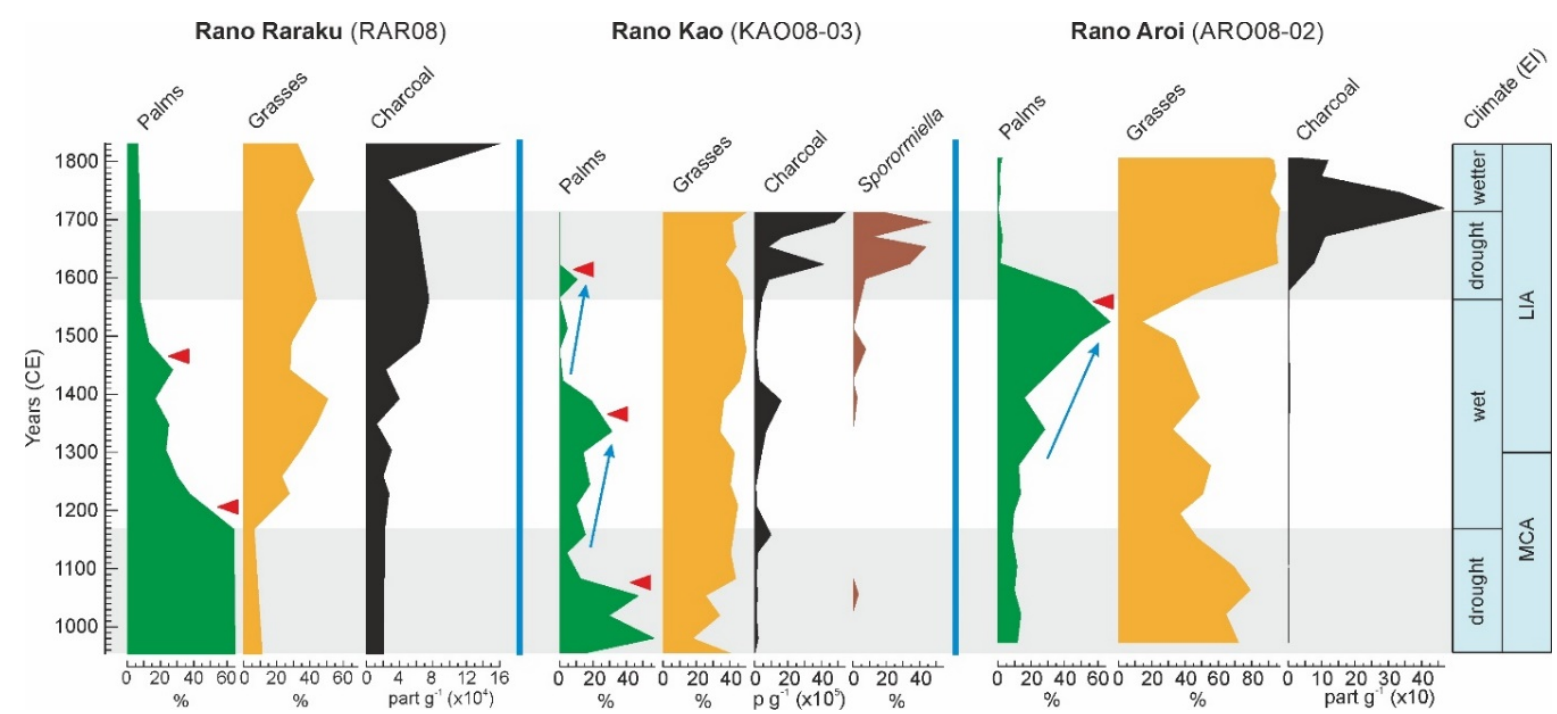

Figure 26 


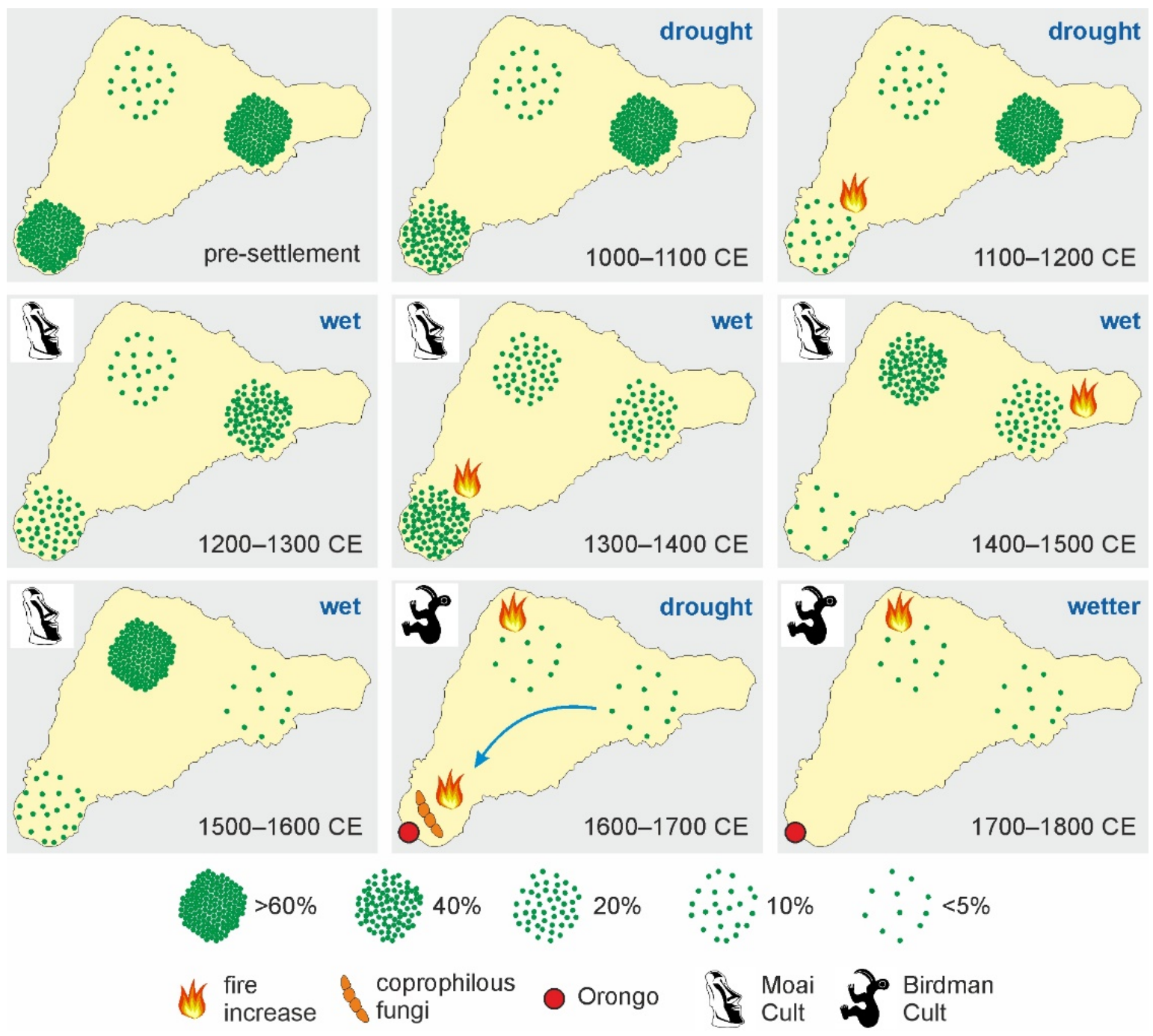

Figure 27 


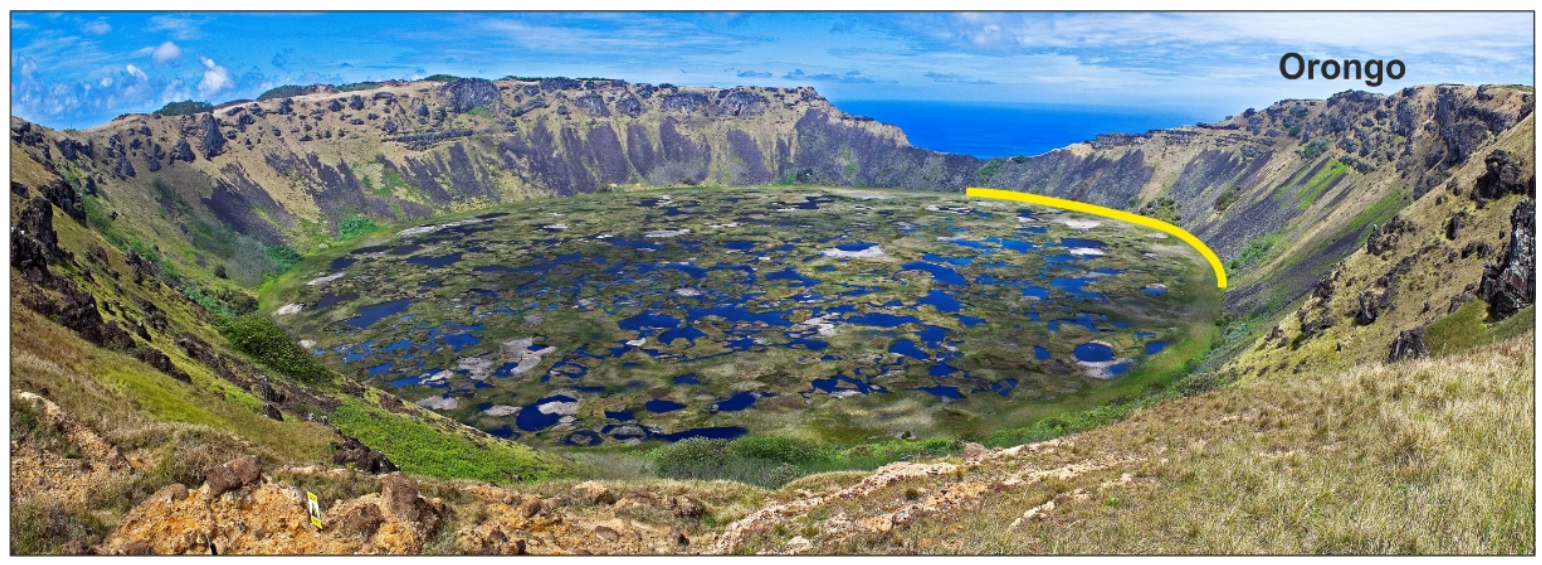

Figure 28 